The copyright of this thesis vests in the author. No quotation from it or information derived from it is to be published without full acknowledgement of the source. The thesis is to be used for private study or noncommercial research purposes only.

Published by the University of Cape Town (UCT) in terms of the non-exclusive license granted to UCT by the author. 


\title{
Energy efficiency in South African industry
}

\author{
by Howard Fawkes \\ Half-thesis for MSc (Mech Eng) \\ Department of Engineering and the Built Environment \\ University of Cape Town
}

August 2003

Supervisor: Prof. K Bennett 


\begin{abstract}
The concept of energy efficiency is not new, but it has been largely ignored in SA industry due to the low cost of South Africa's electricity and a not too distant history of isolation (and lack of international competition) leading up to democratic elections in 1994. This study will show that strong incentives exist for energy efficiency improvement in SA industry. Reduction of GHG emissions, the need to maintain economic competitiveness and the need to delay the cost of a new peak-load electrical generation plant are three objectives that can be achieved through improved energy efficiency in SA and particularly in SA industry.
\end{abstract}

Results from energy projects in industry in the USA and UK show that there is significant opportunity for energy cost saving through energy efficiency improvements. Case study assessments of industry leaders in SA suggest that SA industry has equal, if not greater, potential.

Barriers to the implementation of energy efficiency projects are presented in this study. These barriers need to be anticipated, avoided and/or addressed by policy makers and energy efficiency practitioners. In particular, the lesson from the case study in this thesis showed how organisation structure, financial controls and culture, can be barriers to the implementation of energy projects. By ensuring the support of top management, and by the initiation of an energy management programme early on, these barriers can be avoided. If this can be achieved, then the results and recommendations from the energy assessment can feed into a receptive management system. 


\section{Declaration}

I declare that Energy efficiency in South African industry is my own work, that it has not been submitted before for any degree or examination at any other university, and that all the sources I have used or quoted have been indicated and acknowledged by complete references.

Signed by candidate

Howard Fawkes

August 2003 


\section{Acknowledgments}

I wish to thank Professor Kevin Bennett for his guidance in this thesis.

Thanks also to Mark Howells and Denis Van Es who provided support and expertise during the energy assessment and to Siboniso Khumalo for his work on power factor correction. I also appreciate the help provided by Rosetta Ziegler and the support of Keith Jacobs. Finally, I must thank Thorsten Schulz for his enthusiasm and help in investigating and collecting data on site - even late at night on an empty stomach. 


\section{Table of Contents}

List of acronyms and abbreviations vi

1 Introduction 1

2 Literature Survey $\quad 4$

2.1 Energy use and energy efficiency in SA industry 4

2.2 Incentives for energy efficiency in SA Industry 8

$\begin{array}{ll}2.3 \text { Barriers to energy efficiency in SA Industry } & 13\end{array}$

2.4 Energy cost savings - Experiences from energy programmes $\quad 15$

2.5 Energy management 17

2.6 Efficiency improvement through technology 26

3 Case Study - Energy Assessment of a South African motor vehicle $\begin{array}{ll}\text { manufacturing company } & 28\end{array}$

3.1 Research Methodology 28

3.2 Results 35

3.2.1 Trends in Production and Energy Use 37

3.2.1 Energy Conservation Opportunities 46

ECO 1 - Repair compressed air leaks and faulty blow-down valves $\quad 47$

ECO 2 - Avoid and discourage misuse of compressed air 51

ECO 3 - Switch off ER compressors and main cooling towers during non-

production time 55

ECO 4 - Isolate areas of the plant or individual machines that do not require compressed air during non-production time $\quad 57$

ECO 5 - Install suitable power factor correction equipment 60

ECO 6 - Use waste heat to heat phosphate bath 66

ECO 7 - Install High Efficiency Lighting 68

ECO 8 - Turn off bay lights during non-production hours 76

ECO $9 a$-Install direct acting electric heaters to air replacement

plants serving colour line $\quad 81$

ECO 9b - Extend existing thermic oil/HFO system to supply the

ARP (HFO instead of gas) 83

ECO 10 - Make use of heat pump heat recovery between ARP exhaust and supply air streams 
3.2.2 Additional Items Considered (AIC)

AIC1 - Identify and switch off equipment that is not essential during non-production time $\quad 87$

AlC2 - Spread electrical demand to reduce peak KVA costs 89

AlC3 - Make use of water from effluent plant to reduce water consumption and effluent costs 90

AIC4 - Install skylights and photosensor light controls 91

3.2.3 Outcomes of the assessment presentation to management $\quad 97$

3.2.4 Monitoring and Verification Plan 102

3.2 .5 Implementation $\quad 104$

4 Discussion of Results 106

5 Conclusions 109

Bibliography 110

Appendix A - Pre-assessment Data Form $\quad 114$

Appendix B - Leakage in the compressed air system 118

Appendix C - Lighting levels in the plant 121

Appendix D - Lamp replacement calculations 124

Appendix E - Incremental relamping (spot and group relamping) 127

Appendix F - Condition of skylights in main workplaces 131

Appendix G - Plant layout diagram ? . 134 


\section{List of Acronyms and Abbreviations}

$\begin{array}{ll}\text { AIC } & \text { Additional item considered } \\ \text { ARP } & \text { Air replacement plant } \\ \text { CAPEX } & \text { capital expenditure } \\ \text { CDM } & \text { Clean Development Mechanism } \\ \text { CFL } & \text { Compact flourescent lamp } \\ \text { cfm } & \left.\text { cubic feet per minute (1cfm }=28,317 / / \mathrm{min}=1,699 \mathrm{~m}^{3} / \mathrm{hr}\right) \\ \text { CRI } & \text { colour rendering index } \\ \text { ECO } & \text { Energy conservation opportunity } \\ \text { ERI } & \text { Energy Research Institute (UCT) } \\ \text { GDP } & \text { Gross domestic product } \\ \text { GHG } & \text { Greenhouse gas } \\ \text { HFO } & \text { Heavy fuel oil } \\ \text { HID } & \text { high-intensity discharge } \\ \text { HPS } & \text { high-pressure sodium } \\ \text { KPI } & \text { key performance indicator } \\ \text { KVAR } & \text { kilo-volt amps reactive } \\ \text { LPG } & \text { Liquid petroleum gas } \\ \text { M\&V } & \text { monitoring and verification } \\ \text { MH } & \text { metal halide } \\ \text { mo } & \text { month } \\ \text { MV } & \text { mercury vapour } \\ \text { OECD } & \text { Organisation for Economic Cooperation and Development } \\ \text { PFC } & \text { power factor correction } \\ \text { PPP } & \text { Purchasing power parity } \\ \text { RH } & \text { relative humidity } \\ \text { ROI } & \text { return on investment } \\ \text { SA } & \text { South African } \\ \text { TPES } & \text { Total primary energy supply } \\ \text { UK } & \text { United Kingdom } \\ \text { USA } & \text { United States of America } \\ \text { yr } & \text { year }\end{array}$




\section{Introduction}

Energy efficiency is neither a new nor a complex concept, but it is usually only considered when there are reasonable incentives that are understood by the energy user. Energy efficiency has been largely ignored in South African (SA) industry due to the low cost of SA's electricity and a not too distant history of isolation (and lack of international competition) leading up to democratic elections in 1994. This study will show that strong incentives exist for energy efficiency improvement in SA industry, in particular, the need to reduce greenhouse gas (GHG) emissions, the need to maintain economic competitiveness and the need to delay the cost of new peak-load electricity generation facilities.

This study also provides evidence that energy efficiency projects can save a significant portion of energy costs ( $25 \%$ in this case study). Results from energy projects in industry in the USA and UK as well as other case study assessments of industry leaders in SA suggest that SA industry has the potential for significant savings.

Finding opportunities for energy cost saving is only the first step towards attaining a more efficient industry. For energy cost savings to be realised, these energy conservation opportunities (ECO's) need to be implemented. This thesis describes some of the barriers to implementation of energy efficiency projects in SA industry. These barriers need to be anticipated, avoided and/or addressed by policy makers and energy efficiency practitioners. The case study will highlight the importance of creating a receptive management system by ensuring the support and participation of top management in creating an energy management programme.

This thesis consists of a literature survey of energy efficiency in South African industry, and a case study of a motor vehicle manufacturing company in South Africa. The literature survey will provide the context from where the results of the case study will be discussed. The research 
methodology for the energy assessment is contained within the case study.

The literature survey begins by describing the current status of energy use and energy efficiency in SA industry and comparing our consumption and performance with the rest of the world. The following section presents the incentives that are currently driving the move towards a more efficient industry in South Africa. The third section explores the barriers to implementation of energy efficiency projects that have been experienced by practitioners in South Africa and in other countries. These incentives and barriers will determine whether industries and government will spend money on, and allocate human resources to, energy efficiency programmes. Global warming, economic competitiveness and the capital cost of new electricity generation facilities are the main incentives for energy efficiency improvement, while the low cost of SA coal and electricity is one of the main barriers.

The literature survey also contains sections on proven management techniques as well as a summary of the technologies and techniques that can be used for energy efficiency improvement in industry. . These two sections provide the background that is needed when considering the results of the case study. These sections show that energy needs to be treated as a legitimate input to production, rather than an unavoidable overhead and that apart from efficient technology, the human element is a vital part of any energy management programme.

The case study begins with a brief background to the energy assessment (performed by the author) of a motor vehicle manufacturing company in South Africa. It then moves to the research methodology that was followed while preparing for and conducting the energy assessment. 
The results of this assessment are presented (along with recommendations for each energy conservation opportunity) and this is followed by a discussion of the results. Finally conclusions are drawn from the experience of the energy assessment case study and from the findings of the literature survey. 


\section{Literature survey}

The following two quotes from the White Paper on the Energy Policy of the Republic of South Africa - 1998 provide a good backdrop to this thesis.

"Past governments devoted little attention to energy efficiency in industry, mining and commerce. Greater efficiency will provide financial and environmental benefits, with industry becoming more internationally competitive. Government needs to tap this potential." (DME, 1998 pxi)

"It is estimated that greater energy efficiency could save between $10 \%$ and $20 \%$ of current consumption. Government needs to facilitate increased energy efficiency. Obstacles include: inappropriate economic signals; lack of awareness, information and skills; lack of efficient technologies; high economic return criteria; and high capital costs. Government commits itself-to facilitate greater energy efficiency." (DME, 1998 pxi)

This literature survey begins by showing the current situation of SA industry with respect to energy consumption and efficiency. It goes on to present the current incentives for energy efficiency improvement and the barriers as experienced by energy efficiency practitioners in the USA, UK and South Africa. The following section investigates the financial benefits from energy projects completed in the UK, the USA and South Africa. The final two sections provide some background theory to the case study covering energy management and efficiency improvement through technology.

\subsection{Energy use and energy efficiency in SA industry}

This section will show where SA gets its energy, what it uses its energy for, and how efficiently it uses its energy.

South Africa has enormous reserves of easily accessible coal and has relied on coal as its main energy source. Because of its wealth of coal, 
South Africa has been slow to develop its reserves of petroleum and natural gas. Recent exploration has revealed extensive gas reserves ( $\{3$ triilion cubic feet) (Argus: 15 June 2003) in the Ibhubesi gas field off the west coast but development in this regard is still at the starting blocks. SA is a world leader in the production of synthetic fuels and a regional leader in petroleum refining. The project to pipe gas from Pande and Temane gas fields in Mozambique to Sasol (chemicals) and Secunda (synthetic fuels) in South Africa , is $70 \%$ complete (Argus, 15 June 2003). SA also has Africa's only nuclear power station. Energy sources for the total primary energy supply (TPES) of SA and the world in 2000 are compared in Figure 1 below.

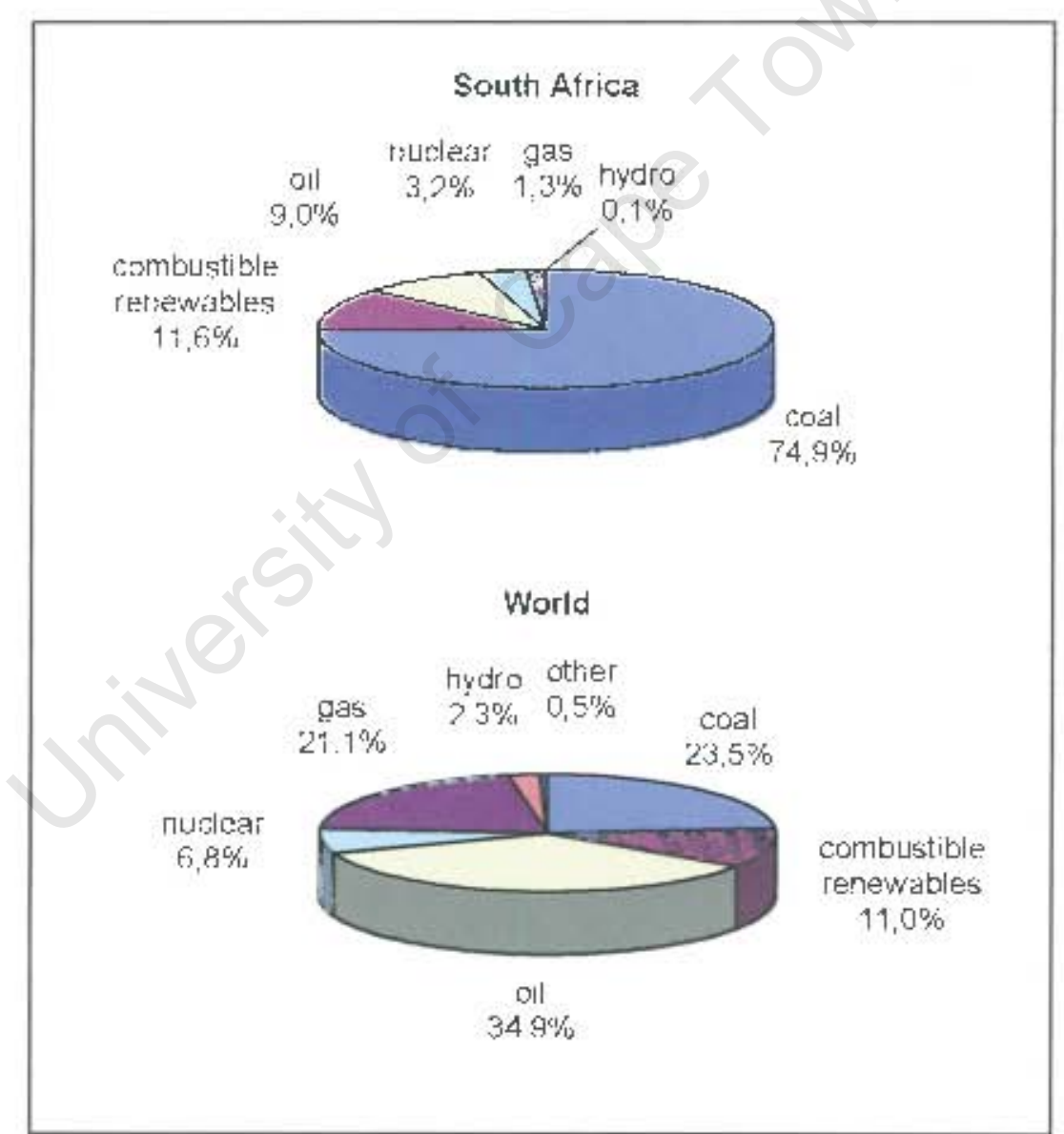

Figure 1 - Energy shares of TPES for 2000 (excluding electrictty trade) (Data source: www.iea.org) 
Final energy consumption in SA is split as shown in Figure 2.

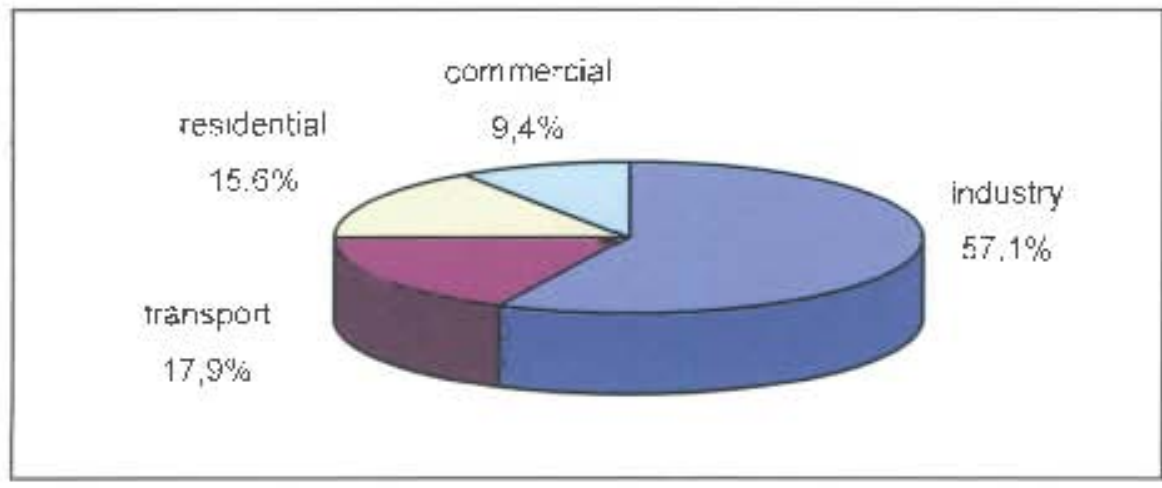

Figure Z - Final energy consumption by sector in SA - 1998 iData source: Environmental Information Agency)

So where is South African industry currently positioned with respect to energy efficiency? Are we efficient. or are we sitting on a 'gold mine' of opportunities for energy cost savings?

The enorgy intensity of a country is an indicator that describes energy use against the value of production or per capita. However, energy intensity by itself, cannot be used as a comparative measure of energy efficiency unless the types of industries of the cauntries are sirnilar. Develaped countries have generally shifted from energy-intensive processes (mining and materials processing) with relatively low product value. to low-energy industries (computer chips, information technology) with relatively high value. Nonetheless, it is still interesting to compare SA's energy intensity with its neighbours and the rest of the world.

Table 1 below shows energy intensity of SA against that of Africa, NonOECD countries, OECD couritries and the World. Total primary energy supply (TPES) per capita is high in OtCD countries and South Africa's TPES/capita is much higher than the African average TPES per gross domestic product (TPES/GDP) shows that South Africa uses almost four times rnore energy than $O \in C D$ countries to produce products of 
equivalent financial value. When purchasing power parity (PPP) is taken into consideration, SA uses just over twice as much energy as OECD countries (and the world average). Electrical consumption per capita shows how South Africa uses ten times more electricity per capita than the African average, uses double the world average and uses about $60 \%$ of the OECD average.

\begin{tabular}{|l|c|c|c|c|}
\cline { 2 - 5 } \multicolumn{1}{c|}{} & TPES/capita & TPES/GDP & TPES/GDP & $\begin{array}{c}\text { Elec. consumption } \\
\text { per capita }\end{array}$ \\
\cline { 2 - 5 } \multicolumn{1}{c|}{ toe/capita } & $\begin{array}{c}\text { toe/000 } \\
1990 \text { US\$ }\end{array}$ & $\begin{array}{c}\text { toe/ 000 PPP } \\
1990 \text { US\$ }\end{array}$ & $\mathbf{k W h} /$ capita \\
\hline South Africa & 2,68 & 0,88 & 0,57 & 4509 \\
\hline Africa & 0,64 & 0,87 & 0,39 & 490 \\
\hline Non-OECD & 0,95 & 0,85 & 0,32 & 975 \\
\hline OECD & 4,63 & 0,25 & 0,26 & 7751 \\
\hline World & 1,64 & 0,37 & 0,29 & 2252 \\
\hline
\end{tabular}

TPES $=$ total primary energy supply, toe $=$ tonnes of oil equivalent, $P P P=$ purchasing power parity, GDP = Gross domestic product

Table 1 - Comparative energy intensity of SA in 1998 (Source:http://www.heliointernational.org)

The high energy intensity that is evident from Table 1 is largely a result of the economy's structure, with large-scale, energy-intensive primary minerals extraction and processing industries dominating. In addition, there is a heavy reliance on coal for generating most of the electricity and for producing a significant proportion of the liquid fuels consumed in the country. Furthermore, South Africa's industry has not generally used the latest in energy-efficient technologies - mainly as a result of low energy costs.

The figures for energy intensity do not prove that SA industry is inefficient but they do show that large quantities of energy are used in our industrial 
processes. For this reason we should expect significant energy cost savings through the implementation of energy efficiency projects.

\subsection{Incentives for energy efficiency in South African Industry}

The driving forces for energy efficiency are:

- profit

- the need to reduce greenhouse gas emissions

- the need to becoming more competitive by reducing energy costs and

- capital investment constraints.

\section{Profit}

Significant financial gain can be achieved through reducing energy costs. Implementing energy efficiency projects and an energy management programme will increase profits. Evidence of this is presented in Section 2.4 - "Energy cost savings - Experiences from energy programmes".

\section{Greenhouse gas emission reduction}

Human activities have added 925 billion tons of $\mathrm{CO}_{2}$ to the atmosphere as well as other greenhouse gasses (GHG's) such as methane and nitrous oxide (Flavin, 1998). These additional gasses intensify the greenhouse effect of Earth's atmosphere, and may cause predicted global warming of $1^{\circ} \mathrm{C}$ by 2025 and $3^{\circ} \mathrm{C}$ by 2100 (IIEC, 1996), more severe weather conditions and rising sea level $(0,65 \mathrm{~m}$ by 2100$)$. In 1998, South Africa produced $1,7 \%$ of the world's carbon emissions (Grobler \& Den Heijer, 2001). The whole of Africa produced approximately $4 \%$ and the USA approximately $24 \%$. Contributions to $\mathrm{CO}_{2}$ emissions by sector in South Africa for 1994 (Howells \& Solomon, 2000) are shown below. 


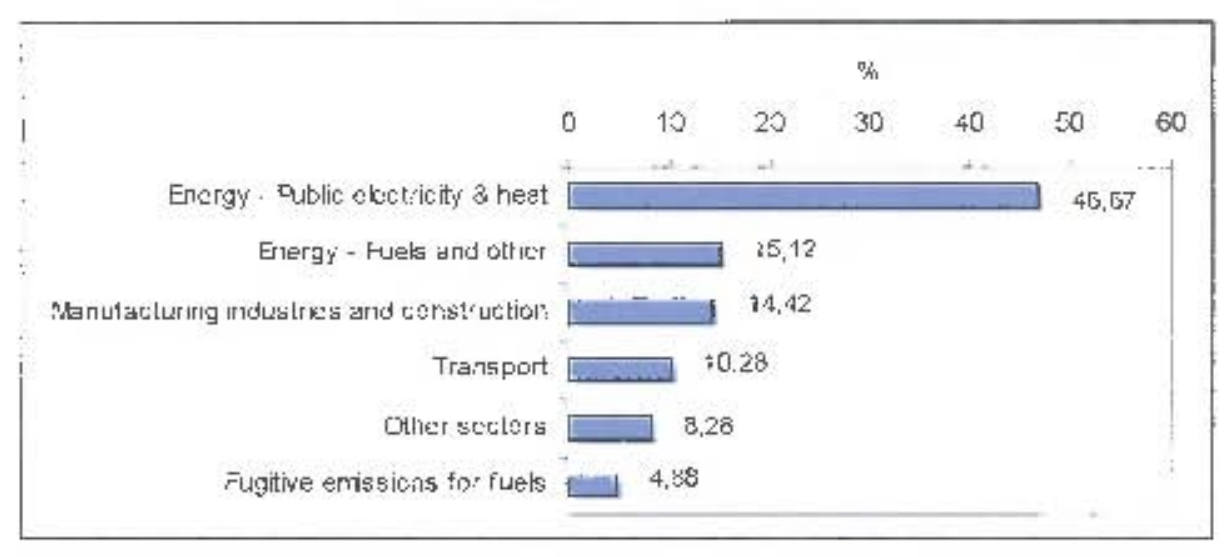

Figure $3-\% \mathrm{CO}_{2}$ emissions for South Africa by sector [1994]

From Figure 3, notably the three largest sources of $\mathrm{CO}_{2}$ emissions are 'Energy - public electricity and heat production' (46,67\%), 'Energy - fuels and other' (15.12\%) and 'Manufacturing industries and construction' $(14.42 \%)$. Together, these three sectors of South African industry contributed $76.21 \%$ of $\mathrm{CO}_{2}$ emissions in 1994

Also noteworthy is that 'public electricity and heat production' also produced $72 \%$ of $\mathrm{CH}_{4}, 100 \%$ of $\mathrm{N}, \mathrm{O} .99 \%$ of $\mathrm{NO}_{2} .82 \%$ of $\mathrm{CO}$ and $55 \%$ of $\mathrm{SO}_{2}$ in 1994. Coal mining produced $21 \%$ of $\mathrm{CH}_{4}$. road transport produced $13 \%$ of $\mathrm{CO}$ and $91 \%$ of non-methane volatile chemicals. $74 \%$ of all $\mathrm{SO}_{2}$ was emitted by 'energy' industries (Howelis \& Solomon, 2000).

The problems of global warming and greenhouse gas emissions have necessitated an international, collective effort that has resuited in the Kyoto Protocol. Forged by 167 nations in December 1997, the Protocol marked the first international attempt to place legally binding limits on greenhouse gas emissions from developed countries. Countries that ratify the agreement (Annex B countries) must seek to achieve emission reduction targets and must develop a legal instrument through which greenhouse gas emissions can be monitored and reduced. On average. the Protocol requires a reduction of fossil fuel emissions of $5.2 \%$ below 
1990 emission levels. South Africa ratified the Protocol on 13 March 2002 , but has not yet negotiated an emission reduction target.

Mechanisms have been built into the Protocol to promote flexibility and cost-effectiveness for developed nations and to provide incentives for developing countries to participate in global emissions reductions without being compelled to do so (Cameron, 2000). These mechanisms are:

- Emission trading - where an Annex B country with excess emission credits may sell emission credits to another Annex B country.

- The Clean Development Mechanism (CDM) - allowing industrialised countries to meet their emission objectives through implementing emission reduction projects in developing countries

- Joint Implementation projects - where Annex B countries may work together to meet their emission targets

- The use of emission sinks - where $\mathrm{CO}_{2}$ is removed from the atmosphere and stored in plants. Projects include forest preservation, forest enhancement through management and the creation of new carbon sinks (plant-rich areas).

These mechanisms, particularly the CDM are potentially valuable sources of funding for energy efficiency projects in South African industry. In the Journal of Energy in South Africa (May 2001), Grobler and Den Heijer state that: "The sector that holds the greatest potential for emission reductions and energy efficiency improvements is the industrial sector, ... (being) responsible for almost $63 \%$ of carbon emissions."

To enter into force, at least 55 nations representing 55 percent of the industrial world's 1990 emissions must ratify the Kyoto agreement. At this stage (August 2003), 111 countries have ratified, accepted, approved or acceded (59 have ratified) however these countries so far only represent $44,2 \%$ of GHG emissions. The USA (contributing $36 \%$ of GHG emissions) has refused to ratify the agreement. President George W Bush has 
refused because he believes it would damage the USA economy, and also because it does not yet require developing countries to cut their pollution in the way developed countries must. At this point it is worth noting that: "Eleven Chinese people and twenty-three Indians have the same $\mathrm{CO}_{2}$ impact as just one American." (Prospex Research Ltd, 2003). The Russian Federation $(17,4 \%)$ has also so far refused to ratify.

The European Union is under pressure to either "persuade" the USA to reconsider, or to push forward for ratification of the agreement without the USA. If the USA chooses not to ratify, they will most likely face economic pressure (environmental sanctions) from the group of countries who have ratified the agreement and are not prepared to accept unfair competition.

\section{The competitive edge}

The opening up of world markets has provided new buyers for South African products but at the same time has introduced new international competition. Developed countries, such as those belonging to the Organisation for Economic Cooperation and Development (OECD), have been steadily improving the energy efficiency of their economies over the past 25 years. In contrast, developing and transitional economies have become less efficient - through rapid industrialisation and investment in inefficient technology.

In their report (IIEC, 1996 p4) for the U.S. Initiative on Joint Implementation, the IIEC point out that..."Developing country industries will not be able to compete when their outdated factories consume three times as much energy as more modern facilities" ...and ..." efforts to cut energy costs and remain competitive are creating lucrative (energy) markets." 
The following graph (Figure 4) illustrates how energy intensities of undeveloped countries have been steadily increasing while intensities of developed countries have been declining between 1970 and 1992 .

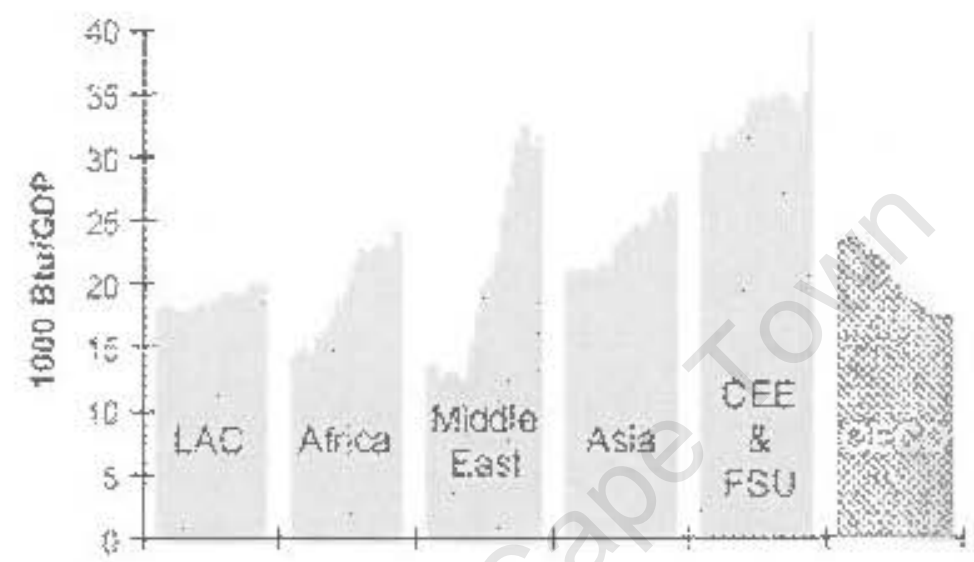

Figure 4 - Energy Intensities by region (1970 - 1992)(Source: IIEC, 1998)

Key: LAC Latin American countrics

CEE Central \& Eastern Europe

FSU Former Soviet Union

OECD Organisation for Economic Cooperation and Development

Capital investment constraints

The public electricity supply company, Eskom, expects that R100 billion of new investment will be required over the next 25 years (Chalmers, 2001). At the same time, the government wishes to privatise Eskom by 2004. In response, Eskom has chosen to invest in energy efficiency projects and demand side management in order to delay the reed for investment in more generating capacity.

It is predicted that current installed capacity will not meet the projected demard iл 2007 and it is intended that demand-side management (negotiated load interruption, load management and reduction) will delay the 2007 deadline to somewhere between 2015 and 2025 (Bennett, 2001). 
The Bonesa initiative is a load reduction project that is a joint venture between Eskom, Africon Engineering International and Umongi-Karebo. It aims to penetrate the South African lighting market with 31,5 million compact florescent light-bulbs (CFL's) that use $75 \%$ less energy and are said to last up to ten times longer than incandescent bulbs (Bennett, 2001).

On the side of managed load interruption, Eskom (in Johannesburg) currently controls 10000 domestic electric water heaters in Cape Town. Eskom offers consumers the choice of 40 different control regimes, which determine the periods when the electrical supply to the water heaters is interrupted (Bennett, 2001).

Projects that receive financial support from Eskom need to be closely monitored and the energy savings verified in order that Eskom can be sure that the investment is worthwhile and so that repayment of capital costs from a portion of the company's energy savings can be calculated.

\subsection{Barriers to energy efficiency in South African Industry}

The potential for significant energy cost savings through improved energy efficiency has been shown in thousands of case studies conducted in the USA and UK and several in South Africa. Despite this record, industry often resists the adoption of energy efficiency.

Research by Kirsch, et al (1996) into the reasons for rejection of energy conservation opportunities by 3612 small and medium manufacturing plants in the USA from 1984 to 1993 showed the following reasons for rejection in 1993:

- $43 \%$ was due to unacceptable financial risk (unsuitable investment return, high initial cost and insufficient cash flow); 
- $25 \%$ was due to postponement (still considering after two years);

- $11,5 \%$ was due to unacceptable plant/person risk (personnel safety, production rate or quality jeopardised, or unacceptable inconvenience);

No comparative study was found for South African industry, however, in a paper presented at the United Nations Educational Scientific and Cultural Organisation (UNESCO) 2001 workshop on "Energy Efficiency in Africa for Sustainable Development", Bennett describes five reasons for resistance to the implementation of energy efficiency opportunities in South Africa. Some of these reasons are quite possibly the 'reasons behind the reasons' stated by Kirsch et al. They are:

1. Attitude: "I know my business best". "No one can tell me how to run my business. No one outside the industry understands my energy problems like I do. I will appear incompetent if outsiders identify savings that I have not seen".

2. Resistance to change. "Everything is going along just fine. Why must we continually be changing and trying new things that will probably not work anyway?"

3. Energy is too cheap. Many users see energy as a minor input cost, relative to raw material and labour, and tend to concentrate on these. Very often, education and examples can provide the incentive for these users to take another look at energy.

4. Lack of capital. Some energy efficiency measures involve the installation of expensive capital equipment. Users are nervous that the promises made by zealous salespersons may not be realised. Once again, education and objective information can go a long way to overcoming these misgivings.

5. Uncertainty regarding the future. Investors are sometimes reluctant to commit resources to long-term projects, given the financial instability both internationally and within regions. Payback periods need to be measured in terms of months rather than years, and this 
can exclude energy efficiency investment opportunities. The lack of long-term commitment has been an on-going problem in Africa with many investors seeing better business opportunities in other regions of the world.

The reasons for resistance to implementation of energy conservation opportunities (including energy management) could be addressed in the following ways:

- Provide education (training) around energy issues

- Create capacity for energy auditing, monitoring and management.

- Disseminate information regarding best practices.

- Use benchmarking, where the specific energy use of competitors is made known (anonymously) for compared within the industry (locally and internationally).

- Shift risk from the plant to the proposer/contractor of the project (capital cost being repaid from a portion of the realised energy cost saving).

\subsection{Energy cost savings - Experiences from energy programmes}

A number of energy efficiency programmes have shown that significant savings can be made.

In 1980, the UK Department of energy initiated a programme that aimed to install effective energy management systems at a quarter of all UK industrial sites that used more than $26000 \mathrm{GJ} / y e a r$. By the end of the programme in 1991, 700 energy information systems had been installed in 22 sectors. By 1987 , overall annual savings of $\$ 120$ million had been achieved and were forecasted to rise to annual savings of $\$ 640$ million by 1995. Some of the average percentage energy cost savings for the 
sectors were $9 \%$ (paper and board), $12 \%$ (non-ferrous metals), 13\% (food) and $17 \%$ (textile finishing) (Caffall, 1995).

A programme in the USA provided technical assistance (energy assessments) from university engineering faculties to 3612 small and medium sized industrial plants in the USA from 1984 to 1993. Implemented energy savings averaged $\$ 19250$ to $\$ 20418$ per plant per year over the ten-year period. The gross sales for these plants averaged $\$ 16,4$ million to $\$ 31,0$ million over the period. Annual recommended energy conservation as a percentage of consumption declined from $9,97 \%$ to $5,24 \%$ over the period. (Kirsch et al, 1996 p4) (Disappointingly, implemented savings averaged from $5,4 \%$ to $2,1 \%$. The reasons for this resistance are discussed in Section 2.3).

Predictably, both the UK and US programmes showed a steady decline in energy savings as a percentage of consumption. As the industry became more efficient, the opportunities for efficiency improvements were reduced - which leads one to the question: "At what stage of 'efficiency development' is South Africa?"

A project to gather and package information on energy efficiency in SA, using three case studies in different industries, was undertaken by the Energy Research Institute (ERI) at UCT. The results show that leading players in SA industry have found room for efficiency improvement. Energy cost savings for South African Brewery's Prospecton plant were R1 370 000/annum ( $8 \%$ of annual energy costs) with a required investment of R1 180000 giving a payback of ten months. Energy cost savings for Anglogold's Elandsrand gold mine were R1 990 000/annum with a required investment of R1 293000 and a payback of eight months. Sappi's Mandini plant was able to save R5 550 000/annum in energy costs ( $5 \%$ of annual energy costs) from an investment of R3 220000 , giving a payback within seven months. 
The case study in this thesis is of a motor vehicle manufacturing plant and another case study from the same sector shows impressive results. The Rover Group in the UK adopted a strategic approach to energy management and managed to reduce their energy consumption per vehicle by $26 \%$ during the 1990 's. These cost-saving benefits have also reduced carbon dioxide emissions per vehicle by 30\% (DETR, 1999 p8) Energy Efficiency Best Practice Programme)

There appear to be opportunities for significant energy savings through energy efficiency improvement in SA industry.

\subsection{Energy management}

Efficient energy management is essential for South African industry if we wish to make a success of energy efficiency projects. A successful energy management system should also remove some or all of the barriers (as discussed in Section 2.3).

This section provides a structured approach to the implementation of an energy management system. It shows that an energy assessment can be seen as an energy management tool. Conversely, experience from the case study will show that in the absence of an energy management system, an energy assessment is quite likely to initiate action towards the establishment of such a system.

\section{Evaluating current energy management}

An energy management matrix such as that shown in Figure 5 (next page) helps an organisation to identify the extent of their energy management practice, and gives them an opportunity to identify where they need to improve. A consistent score is desirable across all the criteria - the aim is to raise the score for each criterion up to the level of the highest scoring criterion. 


\begin{tabular}{|c|c|c|c|c|c|c|}
\hline Score & $\begin{array}{l}\text { Energy } \\
\text { Policy }\end{array}$ & Organising & Motivation & $\begin{array}{l}\text { Information } \\
\text { Systems }\end{array}$ & Marketing & Investment \\
\hline 4 & $\begin{array}{l}\text { Active } \\
\text { commitment } \\
\text { of top } \\
\text { management }\end{array}$ & $\begin{array}{l}\text { Fully } \\
\text { Integrated } \\
\text { into general } \\
\text { management }\end{array}$ & $\begin{array}{l}\text { All staff } \\
\text { accept } \\
\text { responsibility } \\
\text { for saving } \\
\text { energy }\end{array}$ & $\begin{array}{l}\text { A comprehen- } \\
\text { sive system } \\
\text { with effective } \\
\text { management } \\
\text { reporting }\end{array}$ & $\begin{array}{l}\text { Extensive } \\
\text { marketing } \\
\text { within and } \\
\text { outside } \\
\text { organisation }\end{array}$ & $\begin{array}{l}\text { Positive } \\
\text { discrimina- } \\
\text { tion in favour } \\
\text { of energy } \\
\text { efficiency }\end{array}$ \\
\hline 3 & $\begin{array}{l}\text { Formal } \\
\text { Policy but no } \\
\text { commitment } \\
\text { from top } \\
\text { management }\end{array}$ & $\begin{array}{l}\text { Clear } \\
\text { delegation } \\
\text { and } \\
\text { accountabil- } \\
\text { ity }\end{array}$ & $\begin{array}{l}\text { Most major } \\
\text { users } \\
\text { motivated to } \\
\text { save energy }\end{array}$ & $\begin{array}{l}\text { Monthly } \\
\text { monitoring } \\
\text { and targeting } \\
\text { for individual } \\
\text { sections }\end{array}$ & $\begin{array}{l}\text { Regular } \\
\text { publicity } \\
\text { campaigns }\end{array}$ & $\begin{array}{l}\text { Same } \\
\text { appraisal } \\
\text { criteria used } \\
\text { as for all } \\
\text { other } \\
\text { investment }\end{array}$ \\
\hline 2 & $\begin{array}{l}\text { No policy } \\
\text { Adopted }\end{array}$ & $\begin{array}{l}\text { Delegation, } \\
\text { but line } \\
\text { management } \\
\text { and authority } \\
\text { unclear }\end{array}$ & $\begin{array}{l}\text { Motivation } \\
\text { patchy and } \\
\text { sporadic }\end{array}$ & $\begin{array}{l}\text { Monthly } \\
\text { monitoring } \\
\text { and largeting } \\
\text { by fuel type }\end{array}$ & $\begin{array}{l}\text { Some ad- } \\
\text { hoc staff } \\
\text { awareness } \\
\text { training }\end{array}$ & $\begin{array}{l}\text { Investment } \\
\text { with short } \\
\text { term } \\
\text { payback only }\end{array}$ \\
\hline 1 & $\begin{array}{l}\text { Unwritten set } \\
\text { of guidelines }\end{array}$ & $\begin{array}{l}\text { Informal, } \\
\text { part-time } \\
\text { responsibility }\end{array}$ & $\begin{array}{l}\text { Some } \\
\text { awareness } \\
\text { of } \\
\text { importance } \\
\text { of energy } \\
\text { saving } \\
\end{array}$ & $\begin{array}{l}\text { Invoice } \\
\text { checking }\end{array}$ & $\begin{array}{l}\text { Infomal } \\
\text { contact used } \\
\text { to promote } \\
\text { energy } \\
\text { efficiency }\end{array}$ & $\begin{array}{l}\text { Only low } \\
\text { cost } \\
\text { measures } \\
\text { taken }\end{array}$ \\
\hline & $\begin{array}{l}\text { No explicit } \\
\text { policy }\end{array}$ & $\begin{array}{l}\text { No } \\
\text { delegation of } \\
\text { energy } \\
\text { management }\end{array}$ & $\begin{array}{l}\text { No } \\
\text { awareness } \\
\text { of the need } \\
\text { to save } \\
\text { energy }\end{array}$ & $\begin{array}{l}\text { No information } \\
\text { system or } \\
\text { accounting for } \\
\text { consumption }\end{array}$ & $\begin{array}{l}\text { No } \\
\text { marketing or } \\
\text { promotion }\end{array}$ & $\begin{array}{l}\text { No } \\
\text { investment } \\
\text { in energy } \\
\text { efficiency }\end{array}$ \\
\hline
\end{tabular}

Fig. 5: Energy Management Matrix (Source: Good Practice Guide 84, 1993)

Critical factors for an effective energy management programme are:

1) Obtain top management commitment

2) Create an energy policy

3) Obtain commitment from all employees

4) Set up communication channels

5) Change or modify the organisation to give authority and responsibility for the conservation effort and develop an energy management programme.

6) Set up a means to monitor and control the programme.

7) Investment

8) Energy Assessments 


\section{Obtain top management commitment}

The commitment of top management is essential for ensuring investment in energy efficiency projects and for providing a powerful source of leadership and motivation for the programme within the organisation. This commitment should be a formally communicated, financially supported dedication to improving energy efficiency while maintaining or improving the functioning of the facility. The commitment should be active and clearly communicated to all levels of the organisation. For this purpose, an energy policy is required.

\section{Create an Energy Policy}

An energy policy states what an organisation intends doing about energy management and the goals that they hope to achieve. An energy policy is not the same as an energy strategy. The policy defines what the institution intends doing regarding energy whereas the strategy determines how it will be accomplished. An energy policy should be a concise document (one page) and has three essential components:

1) A Declaration of Commitment - where top management declares that the management of energy will be sustained and supported as one of the many vital activities within the institution. For example:

"As an integrated pant of its environmental policy, Total Refrigeration Limited is committed to responsible energy management and will seek to utilise energy efficiency throughout all its premises, processes, plant and equipment" (wmw.totalrefrigeration.co.uk)

2) A Mission Statement - where the focus of the energy management programme is specifically defined. For example:

"Total Refrigeration Limited will seek to:

avoid unnecessary expenditure

$>$ improve cost effectiveness, productivity and working conditions

protect the environment

$>$ prolong the useful life of fossil fuels"

(www.totalrefrigeration.co.uk) 
3) Programme Goals - where the specific objectives of the institution (in order to achieve the mission statement) are determined. The goals will eventually determine whether the energy management programme has been successful or not. For example:

"Our long term objectives are to:

buy fuels at the most economic cost

burn and use them as efficiently as practicable

$>$ reduce the amount of pollution, particularly $\mathrm{CO}_{2}$ emissions, caused by our energy consumption

Deduce, wherever possible and practicable, our dependence on fossil fuels through the use of ambient and renewable energy"

(wmw.totalrefrigeration.co.uk)

A quantifiable target may also be included in the goals. Once a set target has been reached, a new target can be set either along the same line or towards another objective of the energy management programme.

\section{Obtain the commitment of employees}

An energy management programme requires the participation and interest of people at all levels of the organisation. Energy saving ideas must be encouraged with rewards for significant contributions to the programme. Pride is generated in employees when they feel that they are partners in the planning and implementation of a programme that achieves positive results.

The formation of working teams to address specific energy issues can be highly successful. Once the problem is solved, the team is dissolved. For example, a four-person team at Land Rover encouraged paint shop staff to adopt attitudes of ownership and responsibility by rescheduling paint plant operations. As a result, savings of $£ 6000$ per week were achieved, equating to more than $£ 300000$ per year (DETR, $1999 \mathrm{p6}$ ). The importance of energy teams is also emphasised by Mashburn in his article "Planning for an effective energy management programme". According to 
Mashburn, energy teams are "the core of the programme" and teams should:

- be appointed for a specific time period, such as one year. Annual membership rotation can allow new people with new ideas to participate, provides a mechanism for tactfully removing nonperformers, and involves greater numbers of people in the programme in a meaningful way.

- be selected to supplement skills the energy manager lacks. It is unrealistic to think one energy manager can have all the skills.

- have enough technical knowledge to understand the technology used by the organisation, or be trained in that technology

- have a knowledge of potential new energy-saving technologies

- have planning skills that will help establish the organisational structure, plan energy surveys, determine educational needs, and develop a strategic energy management plan

- Understand the economic evaluation system used by the organisation, particularly payback and life-cycle cost analysis

- have good communication and motivational, skills since energy management involves everyone within the organisation

Competition between sections can also generate enthusiasm.

Competitive programmes can be initiated and should be encouraged. Acknowledgement of good ideas, positive reinforcement of good performance and encouragement of teamwork is essential. A clear, concise list of firm do's and don'ts to guide employees in their work can be helpful in improving energy conservation practices. These lists should be updated as often as necessary.

Employee participation can be increased by communicating examples of energy conservation ideas being implemented, photographs of employees who submitted the ideas, and information on the savings realised. Effective communication channels are essential. 
Set up communication channels

The purpose of these channels are to:

- report to the organisation the results of their efforts

- recognise high achievers and to identify reward recipients.

- advertise the programme and to encourage co-operation

The different media available that can be used as communication channels are:

- face to face discussion

- seminars and workshops

- distribution of informative and descriptive literature (newsletters, bulletin boards, email and intranets)

- industrial theatre

- the workplace (management leading by example)

\section{Develop an organisational plan}

An organisational plan should then be developed for both implementing and monitoring specific energy management programmes. This plan should address the criteria as identified in the energy management matrix. also, the plan must:

- define the responsibility of the energy management co-ordinator or committee;

- describe an effective communication system between co-ordinator, section managers and other employees;

- establish an energy accounting and monitoring system;

- provide the means for educating and motivating all employees (management training, energy team training and training for other employees) 
Experience has shown that a $1-2 \%$ reduction in consumption can be achieved after meters are installed just by letting users know that they are being monitored. Up to a $5 \%$ total reduction can occur when users then become proactive in better managing the use of their energy (Caffall 1995).

\section{Investment}

A result of the environmental concerns discussed in Section 2.2, is that there is growing pressure for corporate environmental responsibility to be demonstrated. Management will increasingly need to show a positive discrimination in favour of a "green investments" which would include energy efficiency.

At least, efficiency projects need to be appraised for their savings potential just as productivity improvement projects are appraised for their income generating potential.

\section{Energy Assessment}

An energy assessment determines where and how energy is being used. It identifies measures to improve efficiency and provides a benchmark against which future efficiency can be compared. Conducting a successful energy assessment involves

- Following a methodical auditing procedure

- Determining a pattern of energy use:

- by making use of effective instrumentation

- from available records

- by calculation and or estimation

- Identifying energy conservation opportunities (ECO's)

- Estimating and calculating energy and energy cost savings if the ECO's were implemented, as well as implementation cost and payback period. 
The assessment can be split into two stages:

The preliminary assessment aims to :

- identify the types and overall quantities of energy used (from existing records)

- identify the main energy using equipment

- identify areas where significant savings could be made (ECO's) and which require detailed investigation

- provide an estimate of the savings, implementation cost and payback period that could be expected from implementing the identified efficiency improvements

The detailed assessment involves:

- collection of detailed information on chosen ECO's

- monitoring energy use over a suitable period if necessary

- analysing results (identify seasonal tendencies, unusual changes, base loads and peak loads)

- quantifying energy savings, energy cost savings, implementation cost and payback period

- presenting the results and providing recommendations for implementation of projects in an assessment report

Following the assessment report, a monitoring and verification plan will be necessary that describes:

- How energy consumption should be measured and recorded

- How the baseline energy consumption (if the project was not implemented) is determined (and adjusted)

- How the energy cost savings are calculated

If the company has an energy management system in place then the monitoring and verification process should slot into the existing system. If not, then this is the time to initiate an energy management plan for the company. 


\subsection{Efficiency improvement through technology}

Much information is freely available (particularly from the internet) on methods of improving energy efficiency in industrial plants. For SA industry, a comprehensive set of handbooks (See Bibliography) titled How to save energy and money has been produced by the ERI at UCT.

This thesis will not include a detailed presentation of these methods (since they are readily available in print). However, the energy conservation opportunities that are presented in the case study do have detailed explanations of the methods used for each opportunity, as well as energy cost saving calculations. A summary of the main areas for energy saving in industry are listed below:

- Boilers and furnaces - optimising combustion efficiency, choosing the most economical fuel, boiler/furnace selection, flue gas heat recovery for combustion air or feed water, and insulation (3E Strategy Guidebook 2, ERI)

- Steam systems - 'blowdown' minimisation and blowdown heat recovery, steam pressure optimisation and pipe sizing, efficient condensate return and air removal by steam traps, design for efficient heat transfer, insulation of pipes, repairing steam leaks, heat exchangers and vessels and flash steam recovery (3E Strategy Guidebook 5, ERI)

- Thermic fluid heaters for transferring heat from combustion to a working fluid (like 'thermic oil') - similar to boilers and furnaces

- Electrical systems - power factor correction, reducing maximum demand costs by tariff analysis and load shifting, monitoring and targeting (3E Strategy Guidebook 1, ERI).

- Electric motors - motor starting methods to avoid or reduce the impact of high starting current, use of high efficiency motors, use of star windings for lightly loaded motors, using speed control (variable speed 
drives or multiple speed motors) to control flow instead of throttling, better motor maintenance.

- Process heat confinement - installing/repairing/increasing insulation on equipment surfaces, covering heated tanks with floating insulation, adding covers or curtains at equipment openings (Clark \& Birkmire, 1999).

- Lighting - reducing lighting time (switching off, occupancy sensors), optimising lighting levels, making use of natural light, using high efficiency luminaries, improving light utilisation, improving maintenance (3E Strategy Guidebook 1, ERI).

- Refrigeration - maintenance and design of insulation, monitoring performance, increase evaporator temperature to increase system coefficient of performance (COP), reduce condensing temperature to increase COP, high efficiency compressors, avoiding part-load operation of compressors and pumps (3E Strategy Guidebooks 4 and $6, E R I)$.

- Pumps - pump and impeller selection, pipeline design for lower resistance, flow rate control (3E Strategy Guidebook 1, ERI).

- Fans - selection, minimising duct restrictions (no dampers and sharp bends), not exceeding demand, minimising leaks, use of variable speed drive's where needed, minimising belt slippage.

- Compressed air systems - reducing demand (use, misuse and leaks), using outside (cool) air for compressor intake, efficient distribution, avoiding over-treating, compressor selection and sizing, heat recovery, siting compressor close to point of high demand or heat requirement, monitoring efficiency (3E Strategy Guidebook 3, ERI). 
- The information obtained from the pre-assessment information form and from the discussions with engineers at the plant during the preassessment stage revealed a number of things. Most significantly:

- The plant was large $\left(215000 \mathrm{~m}^{2}\right.$ of floor area - excluding administration buildings). Also, on a previous visit to the company, one of the ERI researchers identified significant potential for improving the energy efficiency of their lighting. It became clear that at least two people would be required to collect this (and other) information.

- Electricity, heavy fuel oil (HFO), liquid petroleum gas (LPG) and paraffin were the three main fuels that were consumed. The central ovens would need to be investigated, as these were the major consumers of HFO, LPG and paraffin. Equipment that consumed large amounts of electricity would need to be identified and investigated.

- Provision of compressed air was a problem. They were running at maximum capacity and consumption had been steadily increasing at a rate that did not tie in with production.

\section{Measuring Equipment}

In preparation for the on-site assessment, the following equipment was assembled:

- A thee-phase electrical data-logger - for if sections of the plant or individual equipment needed to be investigated.

- A laptop computer to process data while on-site, and for setting up the electrical logger.

- An ultra-sonic leak detector for locating compressed air leaks (later found to be completely unnecessary because the leaks were large and easily audible). To obtain a reasonable estimate for leakage rates from individual leaks, a large plastic bag of known volume was placed over the leak and the time for complete inflation was measured. While this method was unsophisticated and in some instances provided much humour, it did also provide a reasonable estimate. It must be noted 
that tables of air loss against hole-diameter are useful for creating awareness around air leaks but can seldom be used for estimating real air leaks (holes in pipes and fittings are seldom cylindrical).

- Thermometers for fluid temperature measurements were used in the investigation into the main water-cooling plant)

- A tachometer for measuring electric motor rotational speed for efficiency calculations (Not used because thermal, compressed air and lighting efficiencies took the lions share of time and focus.)

\section{The On-site Assessment}

The on-site assessment spanned a period of seven days. It was led by the author with assistance from another student from the ERI. The goals for this week were to:

1. establish good working relationships with the plant personnel

2. understand the production processes

3. identify opportunities for significant energy and energy cost savings

4. collect sufficient data so that these potential savings could be quantified

Good records of energy consumption and production were obtained from the plant and the only areas where data had to be recorded were for lighting (lux levels, numbers and location of lights and skylights), compressed air (estimates of individual leaks) and cooling-water (flowrates and temperatures).

The following short diary records the main activities over this period.

\section{Day 1}

- Introductions to the engineering manager, engineers in his department and to plant section managers.

- Walk-through of the entire plant and explanation of the production processes. 
- Meeting with the engineering manager (Agenda: Known areas of energy wastage, focus areas for efficiency investigations, previous energy efficiency investigations, intended programme for investigations in the week ahead.)

Day 2

- Read reports on previous investigations into maximum electrical demand and the compressed air system. (The compressed air report was not entirely credible according to the plant engineer).

- Recorded light level readings (lux levels) and audited the position and number of lights) in the Engine Plant. Findings: Many skylights were very dirty, which reduced indoor natural light significantly. Indoor light levels varied between vastly insufficient and way too much light mostly because of differing success in the use of natural light. Polycarbonate skylights degrade far slower than fibreglass and attract/retain far less surface dirt. Personnel in the Engine Plant said that they had complained about the dirty skylights several times but nothing has happened.

- Investigated compressed air leaks in the Press Shop. Found many large leaks above and below presses. Estimated that two continuously open blow-down hoses were together wasting about $400 \mathrm{cfm}$.

Day 3

- Met with engineers (Agenda: Strategy for the rest of the week (in particular the measurement of compressed air into the press shop) Outcome: Engineers would set up their own logging equipment for days 4,5 and 6.

- Met with the Process Department Manager. Topics of discussion: Thermal and chemical processes in the Paint Shop; water consumption and effluent generation.

- Went into main substations to confirm placement of recording devices and plant electrical layout. 
- Measured light levels and audited lights at Final Assembly. Findings: Light levels were generally higher than necessary. Found several large compressed air leaks and several large fans running unnecessarily.

Day 4

- Engineers indicated that they would only be able to install the compressed air monitoring equipment in a few weeks time because they were struggling to get the instrument to work.

- Audited lights in the Body Shop and completed lighting audit at Final Assembly.

- Checked amp readings of the four main feeders and the incoming supply at the main substation.

- Investigated compressors at Main Compressor House and in the Engine Plant and also investigated water coolers outside the Main Compressor House.

- Measured light levels at the Body Shop and investigated reasons for different levels of light.

- Conducted a walk-through energy audit of the Press Shop, the Body Shop and the ground flour of the Paint Shop (looking for energy wastage of all types as well as high energy-using equipment particularly compressed air leaks, excessive lighting, large compressors, fans, pumps and motors)

Day 5

- Investigated specifications of lighting used in the plant.

- Investigated Paint Shop Electro-coating bath heating.

- Continued the investigation into the water-cooling system at the Main Compressor House

- Investigated switching for all lights and personnel-cooling fans.

- Looked for air leaks at the Assembly Plant. 


\section{Day 6}

- Measured light levels and audited lights inside the Container and Pressed Part

- Conducted a walk-through energy audit of the Assembly Plant.

- Measured light levels in the Press Shop

- Photocopied all necessary drawings and machinery specifications.

Day 7

- Located and quantified air leaks and air wastage in the Paint Shop.

- Measured transmission of light through clear polycarbonate, new translucent polycarbonate (steel store at end of press shop), clean fibreglass and dirty fibreglass

\section{The analysis stage}

After the seven-day on-site assessment the analysis stage began. Further information was obtained from the plant engineers via fax, telephone and e-mail, but the plant was a three-hour air flight away and effectively no longer accessible. The good working relationships established with the plant personnel during the on-site assessment proved to be invaluable.

Energy consumption and production data was processed in order to show and analyse the patterns of energy use and production in the plant. Opportunities for significant energy and energy cost savings were identified, savings were calculated and recommendations were presented. The contents of the document needed to be accessible to non-engineers (accountants, managers and directors with a non-technical background) so every effort was made to present energy conservation opportunities in an easily readable format. The layout was based on the IIAC - Model report of an industrial assessment (Clark, W., et al. 2000). 


\section{The assessment presentation to management}

After sufficient time had elapsed for management to have had access to the report, a presentation was arranged. The purpose of the presentation was:

- to inform management of the issues (if they had not had the time to read, or had not had access to, the report).

- to get feedback from a wider group of managers, directors and engineers around these ECO's. (Only the engineering manager had provided feedback up to this point.)

- to decide on how to approach the implementation of the ECO's and the monitoring and verification of energy savings.

- to find out what sort of management systems (chain of authority, financing of projects, budgets, quality systems, training, communications and personnel) were in place and what could be done to improve energy management within the company.

The results of the presentation are shown in Section 3.2.3 - Outcomes of the assessment presentation to management. 


\subsection{Assessment Results}

The company manufactures passenger cars and light commercial vehicles. Approximately 5500 employees are involved in the production of about 80000 vehicles per annum.

The average energy consumption and associated costs at he plant are summarised in Table 2 below.

\begin{tabular}{|c|c|c|}
\hline Energy type & Usage $\left(1 \mathrm{TJ}=1 \times 10^{12} \mathrm{~J}\right)$ & Annual Cost \\
\hline Electricity (kWh) & $\begin{array}{r}97277000 \mathrm{kWh} \text { per year } \\
350,2 \mathrm{TJ} \text { per year }\end{array}$ & R 14688827 \\
\hline Electricity (kVA) & $\begin{array}{l}17744 \text { kVA per month } \\
\text { energy value not applicable }\end{array}$ & R 6218157 \\
\hline HFO & $\begin{array}{r}4536893 \text { litres per year } \\
162,9 \text { TJ per year }\end{array}$ & R 6319892 \\
\hline LPG & $\begin{array}{r}3459934 \text { litres per year } \\
96,1 \mathrm{TJ} \text { per year }\end{array}$ & R 8393800 \\
\hline Paraffin & $\begin{array}{r}847484 \text { litres per year } \\
30,3 \text { TJ per year }\end{array}$ & R 2067981 \\
\hline Totals & 638,5 TJ per year & R 40551224 \\
\hline
\end{tabular}

Table 2 - Average energy consumption and associated costs

A summary of the energy conservation opportunities and their associated savings, implementation costs and payback periods, is shown in Table 3 on the following page. The energy conservation opportunities recommended and described in this report represent a total value of approximately $R 15000000$ per year. The savings as listed for each opportunity are the savings achievable when implementing each opportunity independently. Some of the recommended measures overlap with respect to savings (also ECO $9 \mathrm{a}$ and $9 \mathrm{~b}$ are mutually exclusive), therefore actual cost savings will be less than the total value of R15 000 000 (more likely in the region of R10 000000 ). 


\begin{tabular}{|c|c|c|c|c|c|c|c|c|c|}
\hline & Description & \begin{tabular}{c|} 
Electric \\
energy \\
conserved \\
(kWh/year)
\end{tabular} & $\begin{array}{c}\text { Electrical } \\
\text { demand } \\
\text { reduction } \\
(\mathrm{kVA})\end{array}$ & \begin{tabular}{|c|} 
HFO \\
conserved \\
(litres)
\end{tabular} & $\begin{array}{c}\text { LPG } \\
\text { conserved } \\
\text { (litres) }\end{array}$ & $\begin{array}{c}\text { Paraffin } \\
\text { conserved } \\
\text { (litres) }\end{array}$ & $\begin{array}{c}\text { Potential } \\
\text { savings } \\
\text { (R/year) }\end{array}$ & $\begin{array}{l}\text { Implementat } \\
\text { ion cost }(R)\end{array}$ & \begin{tabular}{|c|} 
Simple \\
payback \\
(years)
\end{tabular} \\
\hline ECO 1 & $\begin{array}{l}\text { Repair compressed air leaks and faulty blow- } \\
\text { down valves to achieve a } 10 \% \text { leakage target }\end{array}$ & 8001500 & 1080 & & & & 1262000 & 60000 & 0,04 \\
\hline ECO 2 & $\begin{array}{l}\text { Avoid and discourage misuse of compressed } \\
\text { air (blowdown valves and paint-mix room) }\end{array}$ & 1292043 & 174 & & & & 263189 & 30000 & 0,1 \\
\hline ECO 3 & $\begin{array}{l}\text { Switch off ER compressors and main cooling } \\
\text { towers during non-production time }\end{array}$ & 1699908 & & $\overline{(8)}$ & & & 268075 & zero & zero \\
\hline $\operatorname{ECO} 4$ & $\begin{array}{l}\text { Isolate areas of the plant or individual } \\
\text { machines that do not require compressed air } \\
\text { during non-production time }\end{array}$ & 1394403 & & & & & 219896 & 40000 & 0,2 \\
\hline ECO 5 & $\begin{array}{l}\text { Install suitable power factor correction } \\
\text { equipment }\end{array}$ & & 1516 & & & & 516690 & 1007500 & 2,0 \\
\hline ECO 6 & Use waste heat to heat phosphate bath & 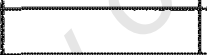 & & 136000 & & & 190000 & 300000 & 1,6 \\
\hline$E \operatorname{Co} 7$ & Install high efficiency lighting & 2110783 & 3072 & & & & 179803 & 628198 & 3,4 \\
\hline ECO 8 & $\begin{array}{l}\text { Turn off bay lights during non-production } \\
\text { hours }\end{array}$ & 2672657 & & & & & 446190 & included & zero \\
\hline ECO 9a & $\begin{array}{l}\text { Install direct acting electric heaters to air } \\
\text { replacement plants serving colour line } 1 .\end{array}$ & & & & \begin{tabular}{|c|} 
tradeoff \\
against \\
electricity
\end{tabular} & & 4355536 & 4000000 & 0,9 \\
\hline ECO $9 b$ & $\begin{array}{l}\text { Extend existing thermic oil/HFO system to } \\
\text { supply the ARP (HFO instead of gas) }\end{array}$ & & & & $\begin{array}{l}\text { tradeoff } \\
\text { against } \\
\text { HFO }\end{array}$ & & 4656666 & 19000000 & 4,1 \\
\hline ECO 10 & $\begin{array}{l}\text { Make use of heat pump heat recovery } \\
\text { between ARP exhaust and supply air streams }\end{array}$ & & & & 1313843 & & 3187385 & 2750000 & 0,9 \\
\hline
\end{tabular}




\subsubsection{Trends in Production and Energy Use}

The following graphs show the trends in production and energy use. Monthly production is compared to total energy costs in Fig 6 below. The dip in production for August 2001 resulted from a weeklong labour strike. The three-week shutdown over December and January also caused a predictable dip

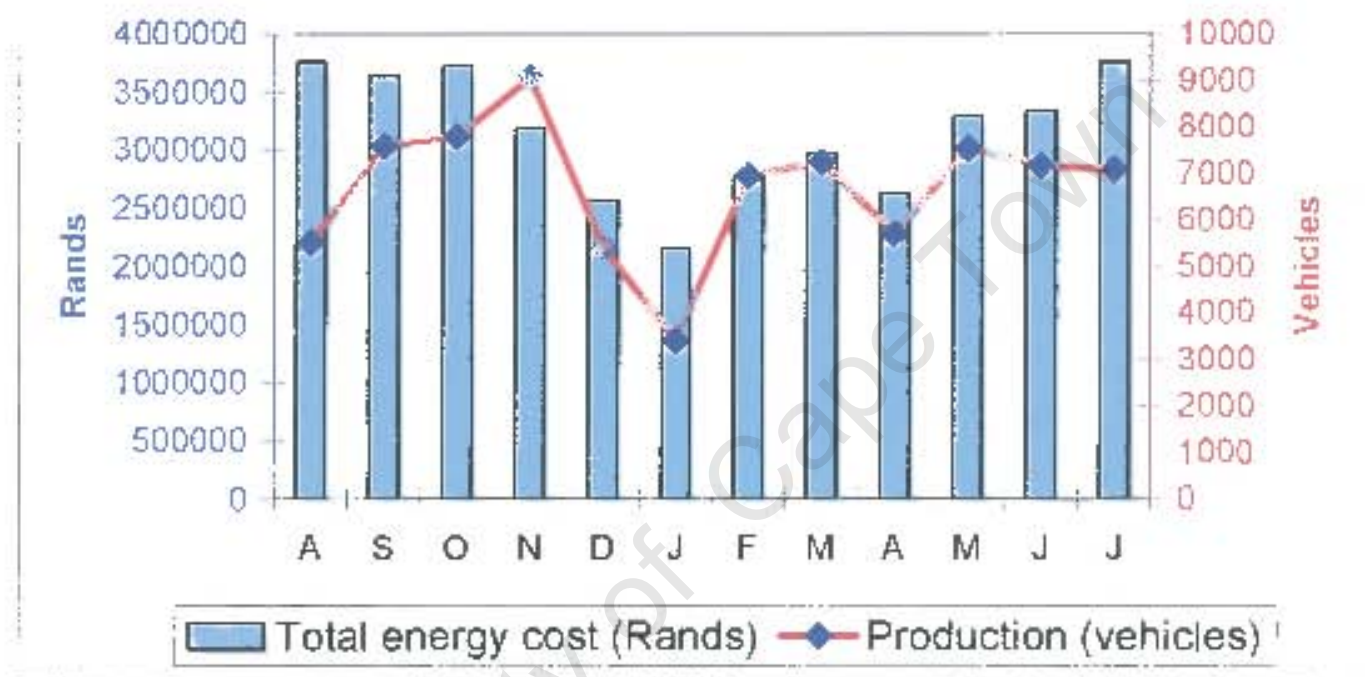

Fig 6 - Production and Total Energy Cost

From Fig 6 above, the ratio of Total energy cost / Production, ranges from $R 680$ / vehicle in August to $R 351$ / vehicle in November. This large difference is due to the impact of seasonal temperature differences on thermal heating requirements of the production process. The effect of seasonal temperatures can be seen in the consumption graphs for HFO and LPG later in this section. The relatively high energy cost /production ratios for December and January are due to two factors. Firstly, the threeweek shutdown over December and January causes lower production during these months. The second factor is that energy is still used through the shutdown period for compressed air, air conditioning, ventilation and lighting 
Monthly electrical energy consumption, maximum demand, and costs for the plant are shown in Figures 7 to 10

Consumption of electrical energy (Fig 8 ) is relatively unaffected by seasonal change (temperature) - possibly because any extra electrical energy used directly or indirectly in heat generation in winter is offset by energy used for air conditioning and process chilling in summer. Also, cooling towers, that run permanently, draw the same amount of energy all the time (whether there is a cooling load or not) The December-january shutdown results in a predictable drop in electrical energy use during these months.

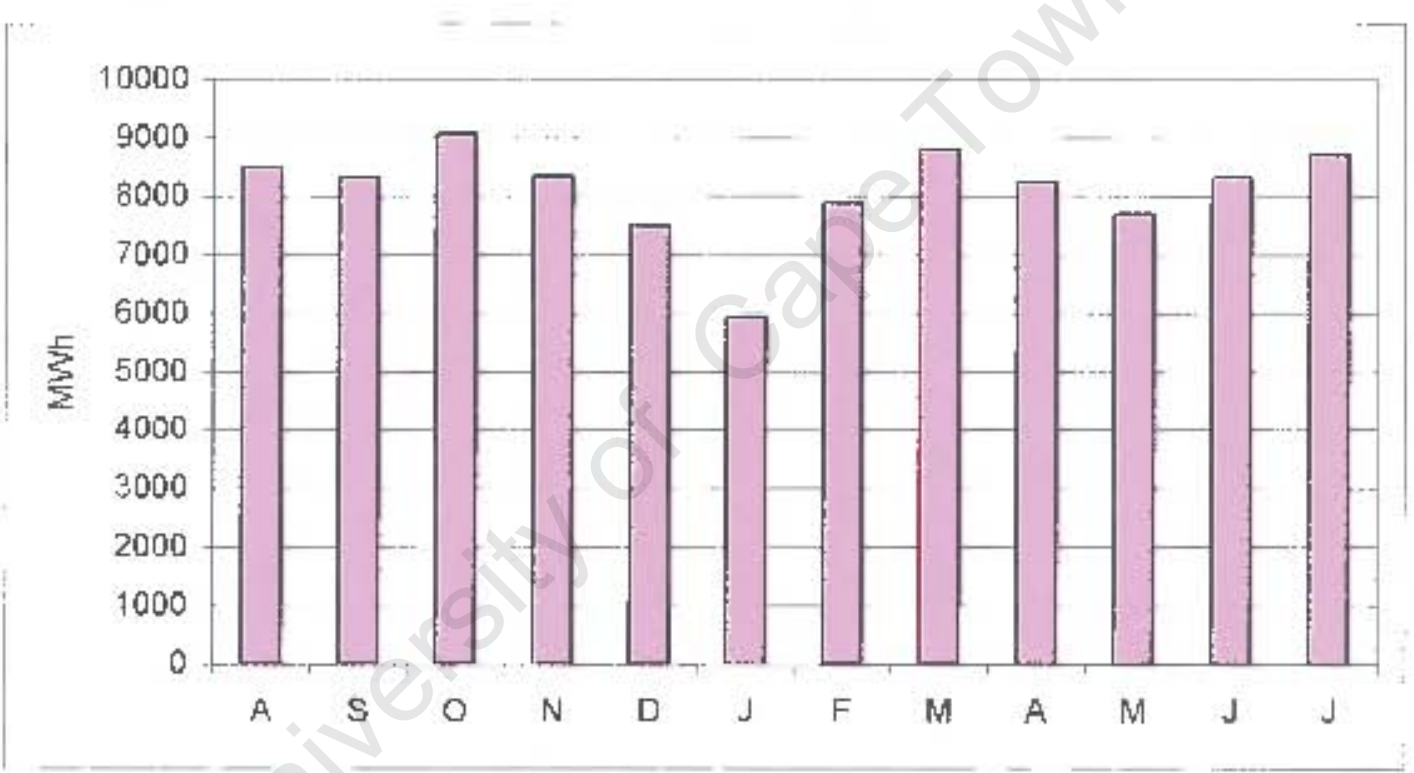

Fig 7 - Electrical Energy Use - Aug 00 to Jul 01

Maximum electrical demand is shown in Fig 8 (following page). 


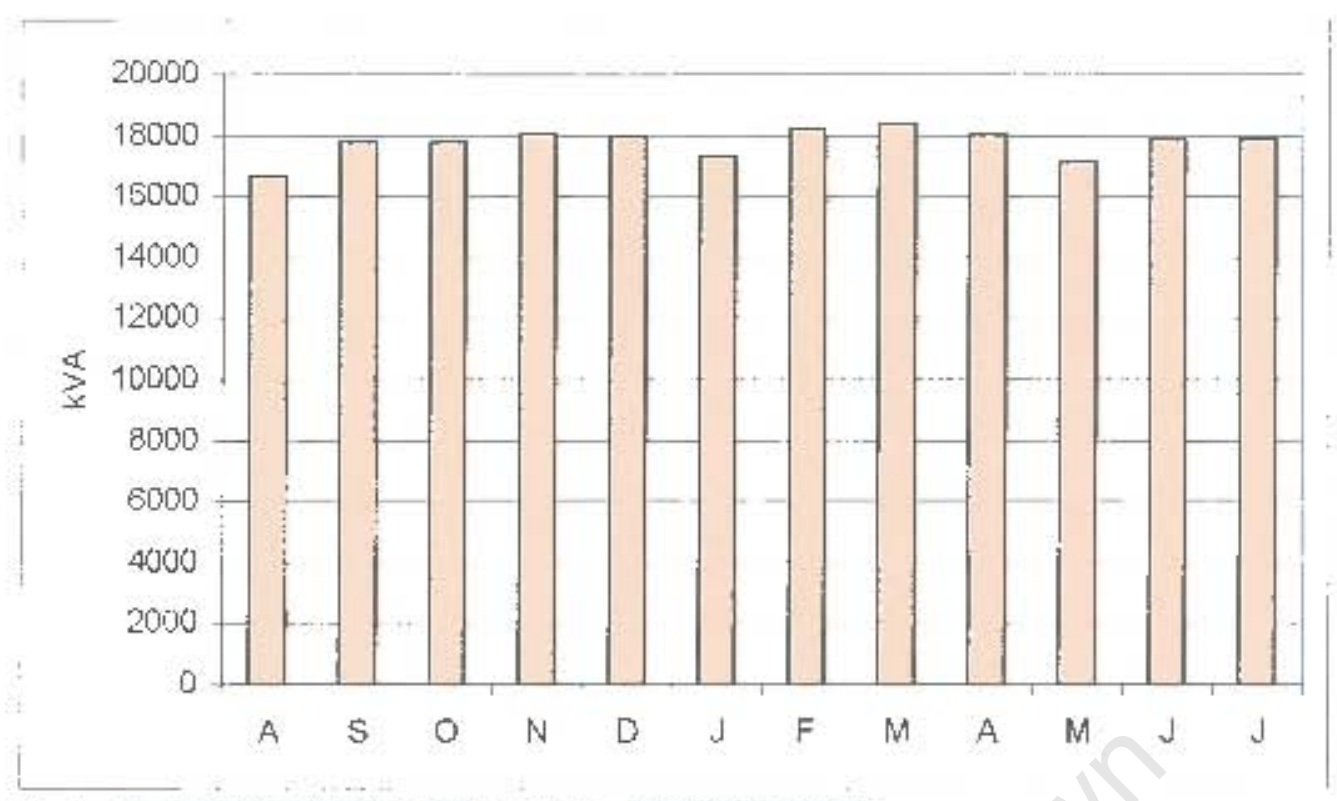

Fig 8 - Maximum Electrical Demand - Aug 00 to Jul 01

Maximum electrical demand is measured as the highest recorded KVA demand in any thirty minute period in a month. A portion of the demand should be related to the maximum intensity of production during that month and a second portion made up of non-production-intensity related kVA demand. There is little seasonal variation in the maximum demand figures.

Plant-wide intensity of production for any hour (or even day) of the month is difficult to quantity. Final production figures are based on vehicles leaving the Final Assembly section and these figures are not necessarily related to the intensity of production in the rest of the plant. Nevertheless there is a small measure of correlation when maximum daily final production is compared to maximum demand for that month (Fig 9 below). 


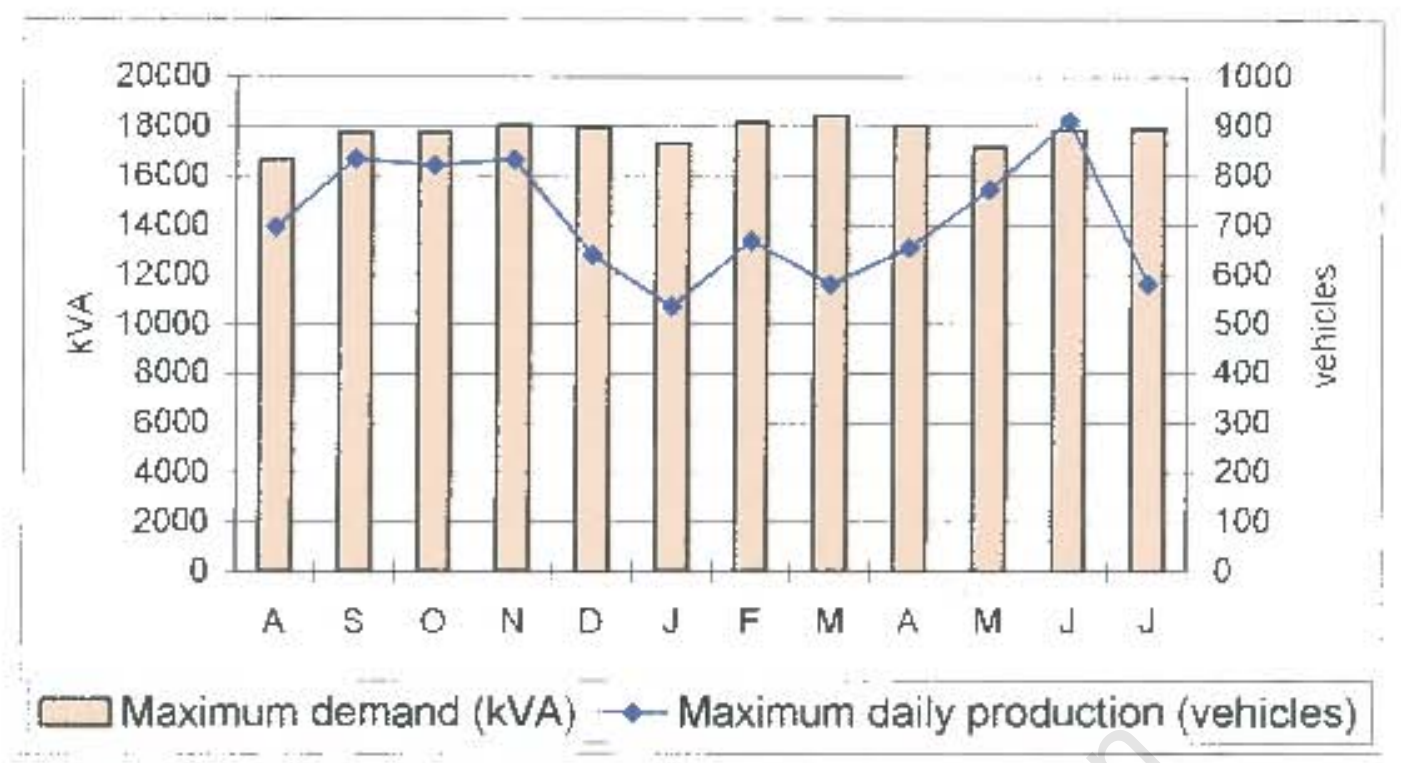

Fig 9 - Maximum Demand vs. maximum daily production

One pattern that stands out fairly clearly is that maximum demand/production intensity ratio is comparatively greater in summer probably due to a larger base load (air-conditioning and ventilation: refrigeration units and water cooling towers).

Electricity costs (Fig 10) echo the kVA and kWh consumption. Maximum demand ( $k$ VA) costs are clearly unrelated to electrical energy ( $k W h$ ) costs in the same way that intensity of production in a particular day is unrelated to the overall production figure for that month. 


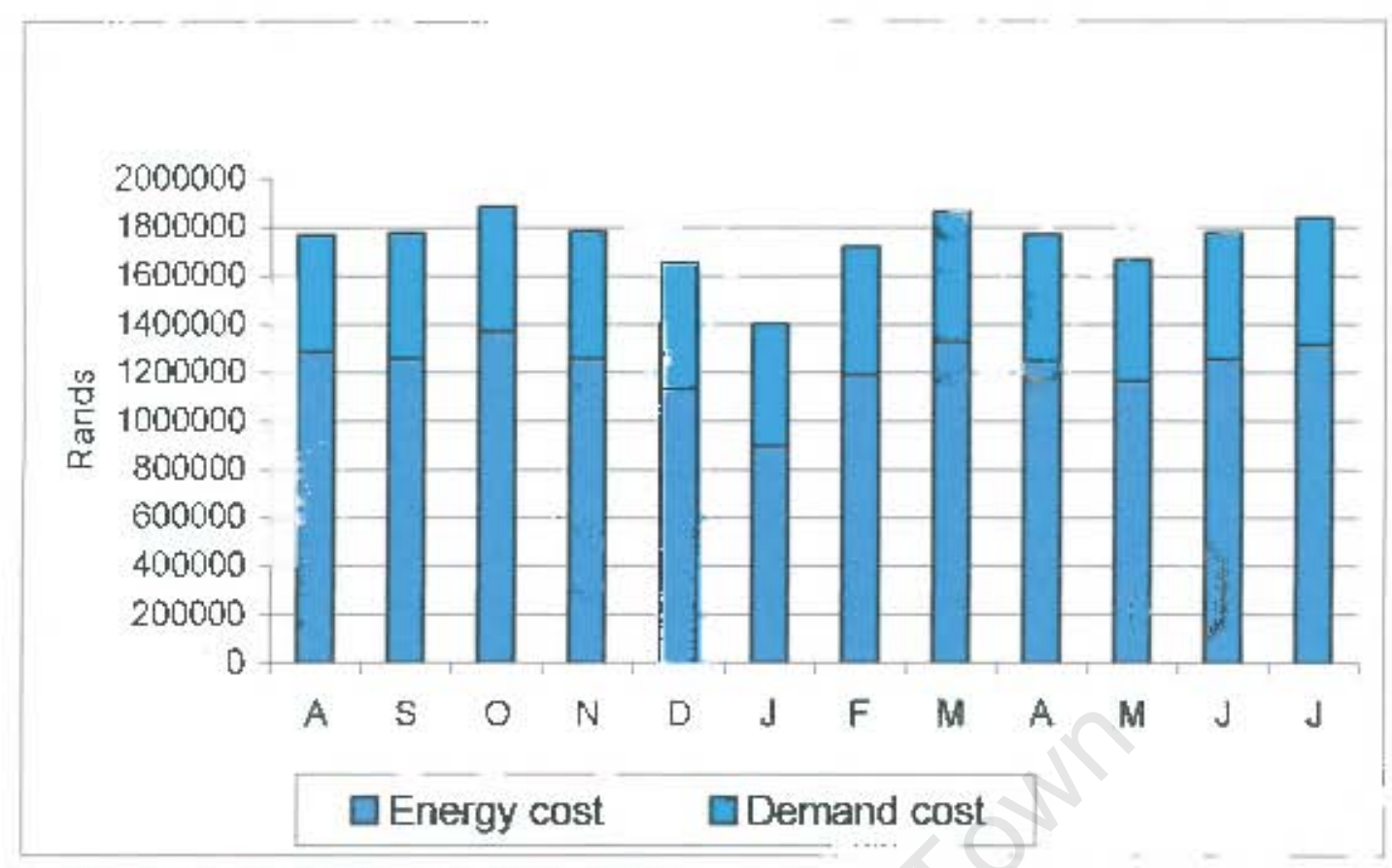

Fig 10 - Electricity Costs - Aug'00 to Jul'01

Figures 11 and 12 show LPG consumption and costs. The use of LPG (entirely for thermal heating) shows large seasonal fluctuation. This close relationship to seasonal temperature fluctuations suggests that there may be opportunities to reduce energy losses through insulation improvement or through conservation and re-use of waste heat. The condition of insulation in the HFO and LPG systems appeared to be acceptable which implies that attention should be given to opportunities for use of waste heat. On average. about 150000 litres are used during the warm summer months and about 400000 litres are used in winter. This means that an extra 250 000 litres per month are required in winter to make up for a seasonal temperature drop of about $15^{\circ} \mathrm{C}$. 


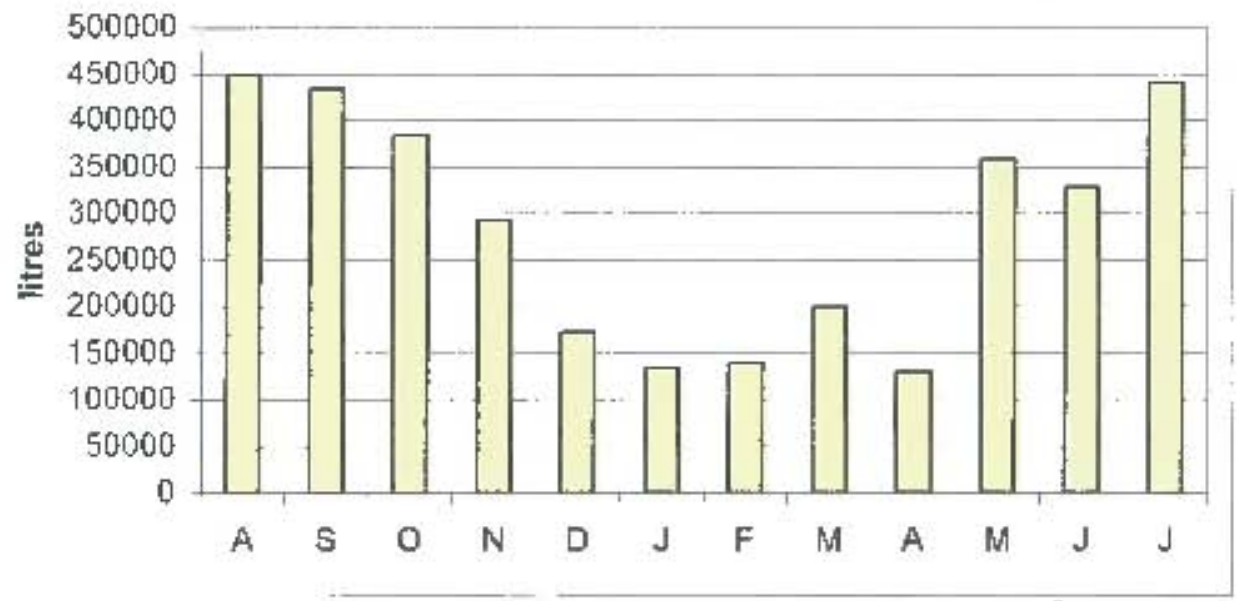

Fig 11 - LPG Consumption - Aug'00 to July'01

Costs have been calculated at a fixed price of $R 2,426$ / litre.

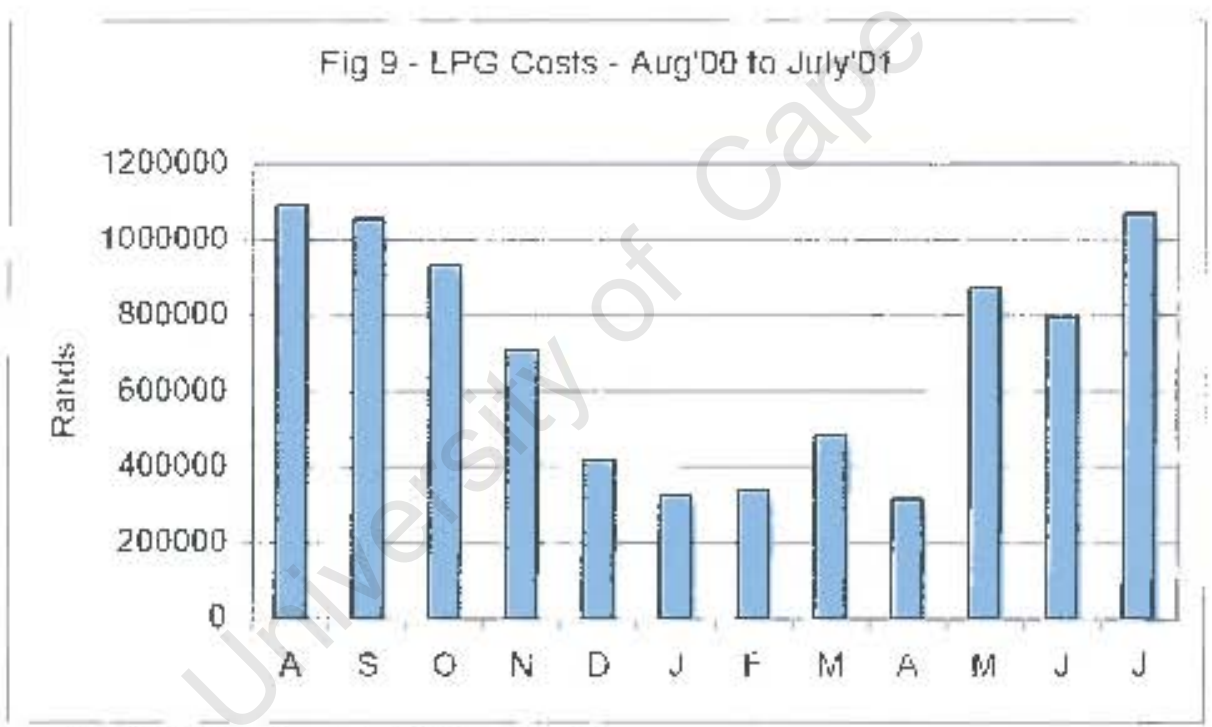

Fig 12 - LPG Costs - Aug'00 to July'01

Figures 13 and 14 show HFO consumption and costs. Again, the seasonal change in the consumption of HFO suggests that there are opportunities for thermal energy conservation (ensuring sufficient insulation and the use of waste heat wherever possible). 


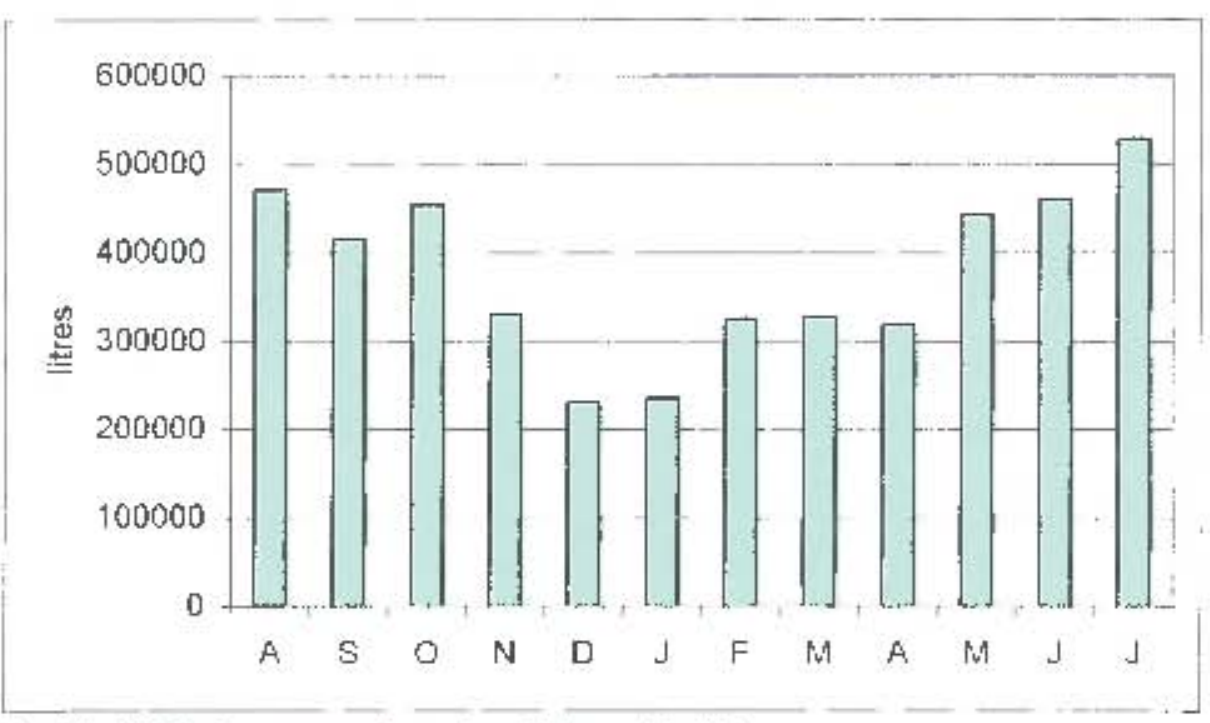

Fig 13 - HFO Consumption - Aug'00 to July'01

Costs for HFO have been calculated at a fixed price of R1,393 / litre.

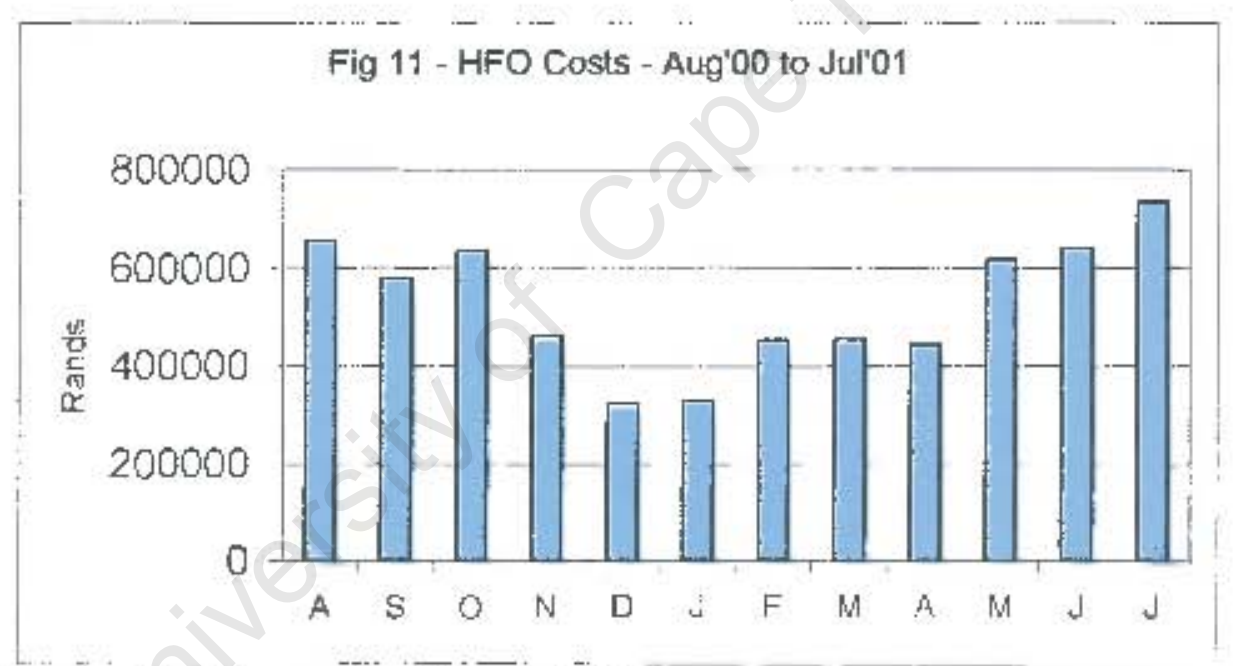

Fig 14 - HFO Costs - Aug'00 to July'01

Figures 15 and 16 show paraffin consumption and cost. Consumption figures for paraffin do not show any meaningful trends. It is likely that the consumption data refers to bulk quantities of paraffin transferred (from one tank to another) and not paraffin used in a particular month. 


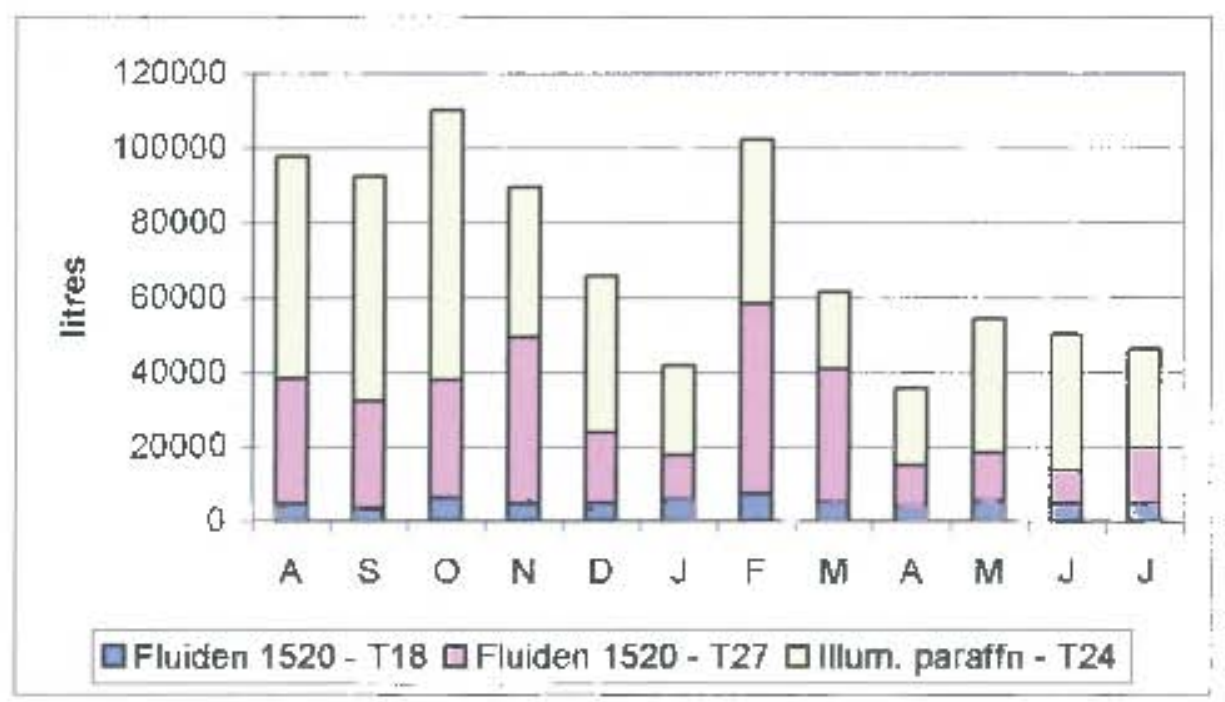

Fig 15 - Paraffin Conșumption - Aug'00 to July'01

Costs for paraffin have been calculated at fixed prices of R2,675 and R2,262 / litre, for Fluiden 1520 and iliuminating paraffin respectively.

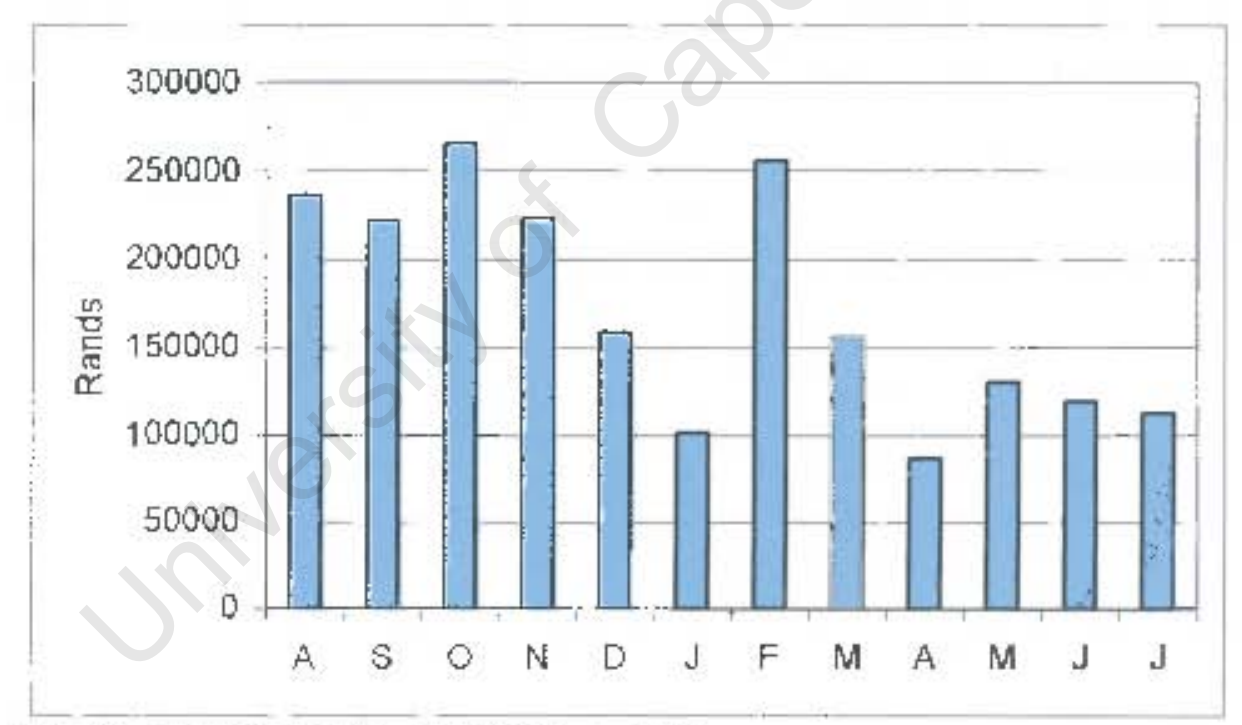

Fig 16 - Paraffin Casts - Aug'00 to July'01

Figure 17 shows the total energy costs for Plant A. Electrical energy is the largest energy cost, closely foliowed by LPG in the winter months. Maximum electrical demand is consistent throughout the year. When taken together (as fuels for thermal heating) LPG and HFO are particularly significant during the winter months, as opposed to the summer months. 


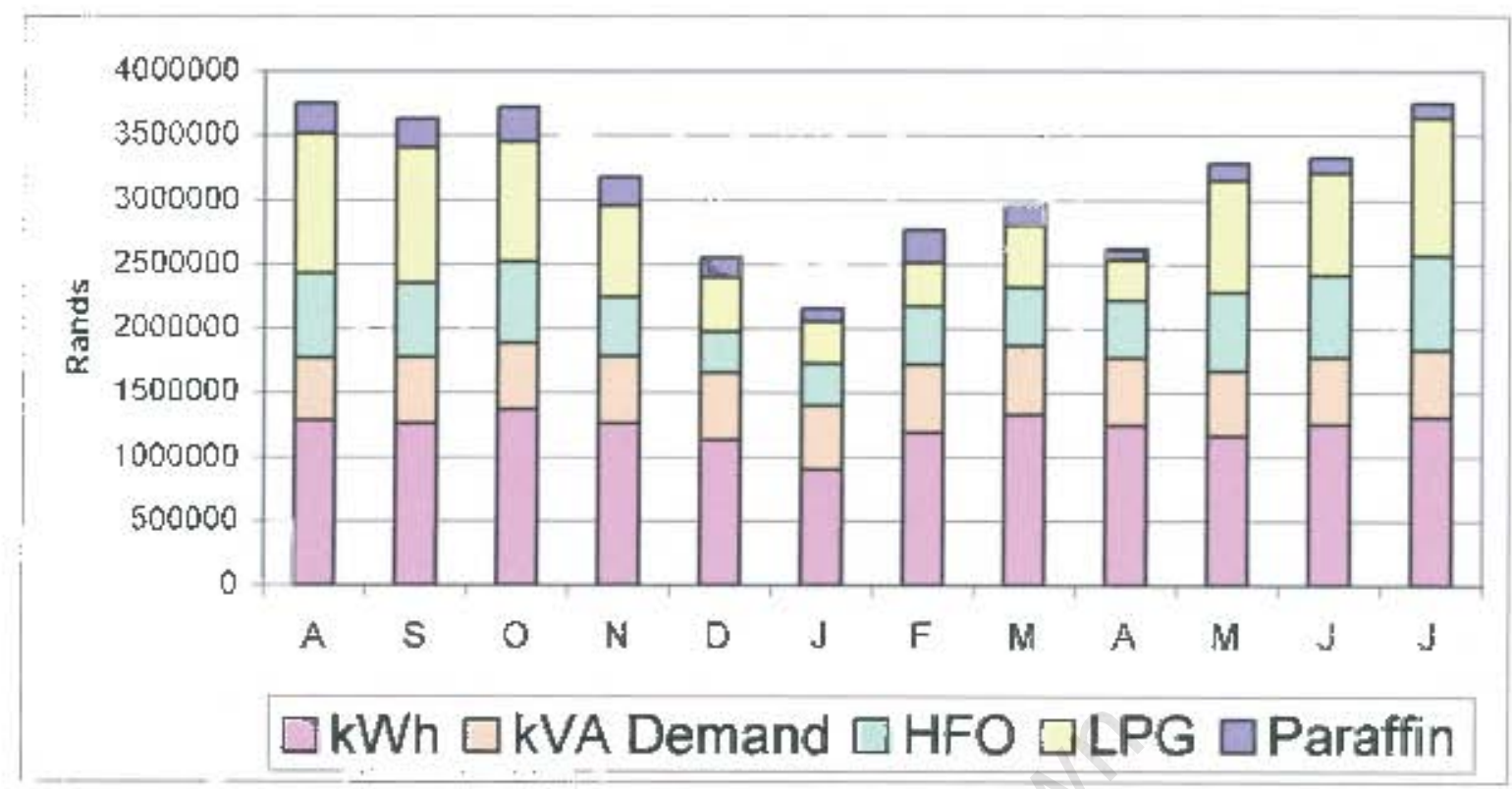

Fig 17 - Energy Costs by fuel type - Aug 100 to July'01 


\subsubsection{Energy Conservation Opportunities}

The following energy conservation opportunities (ECO's) were identified.

The details of these ECO's are presented in this section. Separate recommendations have been prepared for each ECO.

\begin{tabular}{|c|l|}
\hline ECO & \multicolumn{1}{|c|}{ Description } \\
\hline 1 & $\begin{array}{l}\text { Repair compressed air leaks and faulty blow-down valves to achieve a 10\% maximum } \\
\text { leakage target }\end{array}$ \\
\hline 2 & Avoid and discourage misuse of compressed air. \\
\hline 3 & Switch off ER compressors and main cooling towers during non-production time. \\
\hline 4 & $\begin{array}{l}\text { Isolate areas of the plant or individual machines that do not require compressed air } \\
\text { during non-production time. }\end{array}$ \\
\hline 5 & Install suitable power factor correction equipment. \\
\hline 6 & Use waste heat to heat phosphate bath. \\
\hline 7 & Install high-efficiency lighting. \\
\hline 8 & Turn off bay lights during non-production hours. \\
\hline $9 \mathrm{a}$ & Install direct acting electric heaters to air replacement plants serving colour line 1. \\
\hline $9 \mathrm{~b}$ & Extend existing thermic oil/HFO system to supply the ARP (HFO instead of gas) \\
\hline 10 & Make use of heat pump heat recovery between ARP exhaust and supply air streams \\
\hline
\end{tabular}

The following additional items have also received consideration and are presented from Section 3.2.2. Further investigation into these AlC's is recommended.

\begin{tabular}{|c|l|}
\hline AlC & \multicolumn{1}{|c|}{ Description } \\
\hline 1 & Identify and switch off equipment that is not essential during non-production time. \\
\hline 2 & Spread electrical demand to reduce peak kVA costs. \\
\hline 3 & Make use of water from effluent plant to reduce water consumption and effluent costs. \\
\hline 4 & Install skylights and photosensor light controls \\
\hline
\end{tabular}


ECO 1 - Repair compressed air leaks and faulty blow-down valves to achieve a $10 \%$ leakage target

\begin{tabular}{|c|c|}
\hline Estimated electric energy conservation: & $8001500 \mathrm{kWh} / \mathrm{yr}$ \\
\hline Estimated electric energy cost savings: & R $1261836 / y r$ \\
\hline Estimated electric demand reduction: & $1080 \mathrm{kVA} / \mathrm{mo}$ \\
\hline Estimated electric demand cost savings: & R $368064 / y r$ \\
\hline Estimated total cost savings: & R1 $262000 / y r$ \\
\hline Estimated implementation cost: & R 60000 \\
\hline Simple payback: & 2 weeks \\
\hline
\end{tabular}

\section{Recommended Action}

Repair leaks and faulty blow-down valves in compressed air lines on a regular basis with the aim of reaching a $10 \%$ leakage rate.

\section{Background}

Two previous investigations by 'Pascal Projects' have identified the base load (waste) of the main compressed air system as a major cause of wasted energy. During this investigation, base demand (outside production hours) was measured at $6600 \mathrm{~cm}^{1}$ from the three $Z R$ compressors (running at full load) and $625 \mathrm{cfm}$ from one ER compressor (topping up) to give a total base demand (waste) of $7225 \mathrm{cfm}$. This flow rate was required in order to maintain a pressure of 6,7 bar in the line. These investigations also identified the Press Shop (at $3269 \mathrm{cfm}$ ) and the Paint Shop (at $2182 \mathrm{cfm}$ ) as the areas that contributed the most to the high base demand. These investigations reported that the generating cost to meet the base demand was calculated to be greater than $\mathrm{R} 1579000$ per year.

Evidence to support the findings of these two reports was readily available:

- During the assessment week of 6 to 12 August 2001 an extensive list of compressed air leaks (particularly in the press shop) was compiled. This list is presented below.

1. The unit of cubic feet per minute ( $\mathrm{cm}$ ) is not an 150 or 51 unit, however its use is still widespread in South African industry and the world. It was the unit of choice of the engineers and consultants at $W$ and was therefore used for their report. Conversion: $1 \mathrm{cfm}=28,317 \mathrm{~V} / \mathrm{min}$ or $1,699 \mathrm{~m} / \mathrm{hr}$. 
- On Thursday 9 August 2001 (a public holiday) when there was no production, the three $Z R$ compressors ran continuously at full load (6 $600 \mathrm{cfm})$. The cost implications of this will be re-examined.

\section{Compressed air leaks}

The table of 'Leakage in the Compressed Air System', in Appendix B, is intended as a guide for beginning the process of repairing the air leaks. Additional leaks are probable and can be most easily detected and repaired by plant maintenance personnel during non-production periods when the hiss of the air leaks will be easier to detect. Huge and large leaks are bold printed in the table.

\section{The cost of air leaks}

Compressed air manuals set air leakage targets of below $5 \%$ for small engineering works and below $10 \%$ for heavy engineering in harsh conditions. As mentioned already, during a period of no production, three ZR compressors ran continuously at full load (6 $600 \mathrm{cfm})$. Neither of the Centac compressors were running at that time. Owing to the disruption of the labour strikes during the week of the initial site visit it was difficult to be sure of what represented air demand during production time and nonproduction time. For this reason, the findings of the Pascal Projects report will be used as a basis for determining potential savings.

The September 2000 base load was measured at $7225 \mathrm{cfm}$. In order to obtain the amount of air escaping through leaks, the paint mix room requirement (693cfm average) must be subtracted from the base load. This leaves a leakage rate of $6532 \mathrm{~cm}$. The same report states that maximum demand during production is in the region of $13000 \mathrm{cfm}$. From these figures it can be seen that leakage accounts for $50 \%$ of maximum air demand and the amount of air required for useful production is in the region of $6500 \mathrm{cfm}$. 
If we wish to reduce leakage to $10 \%$ of the maximum demand, the 6500 $\mathrm{cfm}$ used constructively in production would represent $90 \%$ of the total air demand and the leakage rate of $10 \%$ can then be calculated at $720 \mathrm{cfm}$. The aim then is to reduce leakage losses from $6530 \mathrm{cfm}$ down to $720 \mathrm{cfm}$ - a difference of $5810 \mathrm{cfm}$ (see diagram below). The target demand would be $7220 \mathrm{~cm}$ ( $6500 \mathrm{cfm}$ plus leakage of $720 \mathrm{cfm}$ ).

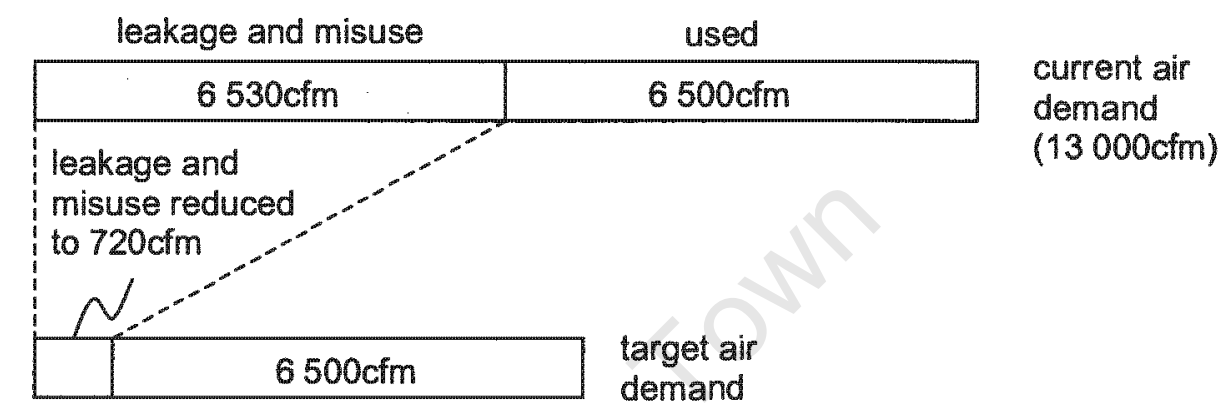

$(7220 \mathrm{cfm})$

A rough energy cost saving can be calculated from the cost that is incurred while running compressors necessary to produce $5810 \mathrm{cfm}$ in the plant.

The costs to run $2 \times$ ER8 compressors at $2200 \mathrm{cfm}$ each as well as approximately 2/3 of a Centac@1333 cfm is the cost of a $5810 \mathrm{cfm}$ leak.

The financial implication of this shown in the table below:

\begin{tabular}{|c|c|c|c|c|c|c|}
\hline \multicolumn{7}{|c|}{ Current alr maximum demand and calculated cost (cooling excluded) } \\
\hline $\begin{array}{l}\text { units } \\
\text { required }\end{array}$ & $\begin{array}{l}\text { compressor } \\
\text { (cfm/unit) }\end{array}$ & $\begin{array}{c}\text { delivered } \\
\text { capacity } \\
\text { (cfm) }\end{array}$ & $\begin{array}{l}\text { total rated } \\
\text { power } \\
\text { (kW) }\end{array}$ & kWh / year * & $\begin{array}{c}\text { energy saving } \\
\text { @ RO, } 1577 \\
/ \mathrm{kWh}\end{array}$ & $\begin{array}{c}\text { demand } \\
\text { saving Q } \\
\text { R28,40/KVA } \\
\begin{array}{c}\text { * } \\
\text { R }\end{array}\end{array}$ \\
\hline 2 & ER8 (2200) & 4400 & 672 & 5531900 & R 872380 & R254464 \\
\hline $2 / 3$ & Centac 2000) & 1330 & $300^{* *}$ & 2469600 & R 389456 & $\mathrm{R} 113600$ \\
\hline & Totais & 5700 & 972 & 8001500 & R1261836 & R 368064 \\
\hline
\end{tabular}

- @ 8232 hours per year (49 weeks/year, 7days/week, 24hours/day)

* $2 / 3$ of $430 \mathrm{~kW}$ is $286 \mathrm{~kW}$, which has been rounded up to $300 \mathrm{~kW}$ to include idling power requirements.

* Total rated power is divided by the overall power factor $(0,9)$, multiplied by 12 (months per year) and multiplied by the demand cost (R32,376/KVA).

The cost of running cooling towers for the above compressors has not been included because the cooling towers of the ER8 compressors are also used for welding tool cooling. Also, the Centac cooling tower would 
need to be on because the Centac would be cycling on and off intermittently during production time. A calculated saving of roughly R1 630000 per year can be expected if the leakage rate is reduced from $50 \%$ down to $10 \%$ (an amount of about $5810 \mathrm{~cm}$ ).

\section{Implementation Cost}

The cost of fixing the leaks is extremely difficult to determine - mainly because it is difficult to be sure of exactly how many leaks there are. Also it must be pointed out that misuse (leaving drain hoses open) will severely hamper any progress towards a lower leakage target. The aspect of misuse is dealt with in the next section.

For the purposes of getting a feel for the advantage of fixing the leaks, if the table of 62 leaks was addressed at a price of R500 per leak the cost would R30 000. Even if double the amount of leaks must be fixed in order to reach the $10 \%$ target, the amount of $R 60000$ required to fix them is small compared to the $\mathrm{R} 1630000$ saving. The simple payback period is 0,4 months ( 2 weeks).

A better way to look at the numbers is to consider what a saving of R1 800000 would justify in terms of long term action. The calculated saving would appear to justify either regular contracted leak detection and repair services or the full-time employment of several people dedicated to monitoring, detecting and repairing compressed air leaks and preventing misuse. 
ECO 2 - Avoid and discourage misuse of compressed air

\begin{tabular}{|c|c|c|}
\hline & Blowdown valves & Paint mix room \\
\hline Estimated electric energy conservation: & $543310 \mathrm{kWh} / \mathrm{yr}$ & $748733 \mathrm{kWh} / \mathrm{yr}$ \\
\hline Estimated electric energy cost savings: & R $85680 / y r$ & $\mathrm{R} 118075 / \mathrm{yr}$ \\
\hline Estimated electric demand reduction: & $73 \mathrm{kVA} / \mathrm{mo}$ & $101 \mathrm{kVA} / \mathrm{mo}$ \\
\hline Estimated electric demand cost savings: & R $24993 / y r$ & $\mathrm{R} 34441 / \mathrm{yr}$ \\
\hline Estimated total cost savings: & $\mathrm{R} 110673 / \mathrm{yr}$ & R $152516 / y r$ \\
\hline Estimated implementation cost: & free & R 30000 \\
\hline $\begin{array}{l}\text { Simple payback: } \\
\text { months) }\end{array}$ & immediate & 0,20 years $(2,4$ \\
\hline
\end{tabular}

\section{Background}

Apart from extensive air leaks, misuse of the compressed air system was evident in some sections of the plant. It must be noted however that the week spent in the plant provided only a snapshot in terms of usual practice in the plant. The engineering and plant personnel are in a better position to determine the level of misuse of compressed air.

In the Press Shop, it was noticed that two blow-down valves were left open for the entire assessment week.

In the Assembly Hall (noticed late Friday night), a valve on a workstation hose (possibly used as a blow-down hose) had been left open. The lever shut-off valve could not be easily reached because it was located about $3 \mathrm{~m}$ above the floor. The end of the hose had been loosely secured to a nearby column to prevent it from making a noise and flailing around.

It is possible that each of these cases were rectified immediately after the weekend - but it is also possible that the three hoses blow freely for most of each year, 24 hours per day. Evidence to support the latter scenario, is the recommendation, in the 'Pascal Projects' compressed air report, that "manual condensate drains should be closed". 
The engineering personnel drew attention to two examples of compressed air misuse in the Paint Shop. Firstly, condensation on the paint mix motors was being removed by blowing the motors with jets of compressed air. We understand that an alternative, low-pressure cooling/drying system has been proposed.

A second example was of compressed air being bubbled into a process tank to agitate the liquid inside. In each case, the compressed air 'does the job' but much energy is wasted in the process.

The process of compressing air takes a large amount of energy because during compression of air, about $90 \%$ of the energy for compression is converted to heat. This heat is usually lost in the cooling towers (unless it can be used constructively, for example for space heating in a cold climate or to provide necessary heat to a production process). In both the cases described in the Paint Shop, compressed air is being used for blowing (a low pressure activity). Low-pressure air can be produced more economically from a fan because no heat of compression is generated and lost.

The cost of compressed air misuse

To get a feel for the magnitudes of wastage, it may be useful to approximate the cost of some of the examples of misuse mentioned above:

\section{Blow-down valves}

For the three manual blow-down valves left open the total cost is in the region of $R 180000$ per annum. These three blow-down pipes have been included in the list of 62 leaks of the previous section. 


\begin{tabular}{|c|c|c|c|c|c|c|}
\hline \multicolumn{2}{|c|}{ Location } & \multirow{2}{*}{$\begin{array}{l}\text { Description } \\
10 \mathrm{~mm} \text { ID drain } \\
\text { hose, } \\
\text { permanently open } \\
\text { (during entire } \\
\text { week), } 6 \text { bar }\end{array}$} & \multirow{2}{*}{$\begin{array}{c}\text { Estimated } \\
\text { loss for an } \\
8 \mathrm{~mm} \text { hole } \\
(\mathrm{cfm})\end{array}$} & \multirow{2}{*}{$\begin{array}{c}\text { Power } \\
\text { loss } \\
(\mathrm{kW})\end{array}$} & \multirow{2}{*}{$\begin{array}{c}\underset{*}{\text { Energy cost }} \\
\text { R } 28560\end{array}$} & \multirow{2}{*}{$\begin{array}{c}\begin{array}{c}\text { Demand } \\
\text { cost * }\end{array} \\
\text { R } 8331\end{array}$} \\
\hline $\begin{array}{l}\text { Press } \\
\text { Shop } \\
\text { ground } \\
\text { level }\end{array}$ & $\begin{array}{l}\text { Electrical } \\
\text { cabinet } \\
\text { (EC) } 7849\end{array}$ & & & & & \\
\hline $\begin{array}{l}\text { Press } \\
\text { Shop } \\
\text { ground } \\
\text { level }\end{array}$ & $\begin{array}{l}\text { Between } \\
\text { EC's TAG- } \\
4628 \text { and } \\
\text { TAG-4888 }\end{array}$ & $\begin{array}{l}10 \mathrm{~mm} \text { ID } \\
\text { blowdown pipe } \\
\text { permanently open } \\
\text { (whole week), } \\
\text { 6bar }\end{array}$ & $150 \mathrm{cfm}$ & 22 & $R 28560$ & R 8331 \\
\hline Assembly & $\begin{array}{l}\text { station } 54 \\
\text { alongside } \\
\text { stairway in } \\
\text { isle F }\end{array}$ & $\begin{array}{l}\text { open } 10 \mathrm{~mm} \\
\text { IDhose (tied to } \\
\text { column to prevent } \\
\text { it from thrashing } \\
\text { around), } 6 \text { bar }\end{array}$ & $150 \mathrm{cfm}$ & 22 & $R 28560$ & R 8331 \\
\hline & & & $450 \mathrm{cfm}$ & 66 & R 85680 & R 24993 \\
\hline & & & \multicolumn{2}{|c|}{ Total } & \multicolumn{2}{|c|}{ R 110673} \\
\hline
\end{tabular}

${ }^{*}$ kilowatts $\times 8232$ hours per year (49 weeks/year, 7 days/week, 24 hours/day) $\times 0,1577$ $\mathrm{R} / \mathrm{kWh}$

* kilowatts divided by overall power factor $\times 12$ months $\times 28,40 \mathrm{R} / \mathrm{kVA}$

\section{Anticipated savings}

From the table above, savings, from ensuring that just three blowdown valves are closed after use, amount to $R 110673$ per year (543 $310 \mathrm{kWh}$; 73 kVA). There is no cost associated with closing valves.

\section{Paint-mix room}

On average, $693 \mathrm{cfm}$ is used in the paint mix room. A small amount of compressed air is used for operating a small hoist and also for some small pneumatic equipment in the room. Most of the compressed air is used in the motor cooling/drying system that consists of:

- 9 motors each cooled by 8 jets of air from a $5 \mathrm{~mm}$ hole in a $25 \mathrm{~mm}$ pipe $(72 \times 5 \mathrm{~mm}$ holes $)$

- 12 motors, each cooled by 3 jets from a $5 \mathrm{~mm}$ hole in a $25 \mathrm{~mm}$ pipe ( $36 \times$ $5 \mathrm{~mm}$ holes)

The $25 \mathrm{~mm}$ pipes have shut off valves installed so air pressure at jet holes is unknown. For this reason, flow rate cannot be easily estimated. If it is 
assumed that about $90 \%$ of air going to the paint mix room is used in the motor drying process, then this means that about $620 \mathrm{cfm}$ is being lost through the motor drying system.

The cost of using compressed air to dry mix motors is:

electrical energy cost $\quad=620 \mathrm{cfm} \times 0,1467 \mathrm{~kW} / \mathrm{cfm} \times 8232 \mathrm{hrs} / \mathrm{yr} \times$ $\mathrm{RO}, 1577 / \mathrm{kWh}$

$$
\begin{aligned}
= & \mathbf{R} 118075 / \mathrm{yr} \\
\text { electrical demand cost } \quad= & 620 \mathrm{cfm} \times 0,1467 \mathrm{~kW} / \mathrm{cfm} \div 0,9 \times 12 \mathrm{months} / \mathrm{yr} \\
& \times \mathrm{R} 28,40 / \mathrm{kVA} \\
= & \mathrm{R} 34441 / \mathrm{yr}
\end{aligned}
$$

Total cost of using compressed air to dry mix motors is $R 152516$ per year.

Implementation Costs

If replacement of the current motor drying system with suitable ducting and a $500 \mathrm{~W}$ fan costs in the region of $\mathrm{R} 30000$, with running costs in the region of R1 000 per year. The simple payback period for this installation is about two months. 
ECO 3 - Switch off ER compressors and main cooling towers during non-production time.

$\begin{array}{ll}\text { Estimated Electric Energy Conservation } & 1699908 \mathrm{kWh} / \mathrm{yr} \\ \text { Estimated Electric Energy Cost Savings } & \mathrm{R} \mathrm{268} \mathrm{075/ \textrm {yr }} \\ \text { Estimated Electric Demand Reduction } & \text { none } \\ \text { Estimated Implementation Cost } & \text { none } \\ \text { Simple Payback } & \text { immediate }\end{array}$

\section{Recommended Action}

Switch off the ER8 compressors and the three main cooling towers outside the main compressor house during non-production time.

\section{Anticipated savings}

The two ER8 compressors use cooled water from the three large packaged cooling towers (Universal Airbrand NCM 8600) outside the main compressor house. This cooled water is also used for welding tool cooling in the body shop during production time. The current base load in the plant is about $6600 \mathrm{cfm}$. This base demand can be supplied by the three ZR compressors and one Centac (The Pascal Projects report recommends that the ER compressors be used as little as possible because they are introducing water and oil into the compressed air system). At the moment, the NCM 8600 cooling towers run continuously, (in case the ER8 compressors are required). Electrical energy savings (see table below) can be achieved if these cooling towers were turned off during non-production time (23:00, Friday to $05: 00$, Monday, and 23:00 to 05:00 of each weekday - a total of 84 hours / week). Maximum demand cost savings will not be achieved since maximum demand does not occur during non-production time. 


\begin{tabular}{|c|c|c|c|c|c|}
\hline Motor & $\begin{array}{c}\text { Shaft } \\
\text { power } \\
\text { rating }(\mathrm{kW})\end{array}$ & $\begin{array}{c}\text { Rated real } \\
\text { power (kW) }\end{array}$ & $\begin{array}{c}\text { Utilized } \\
\text { power } \\
(\mathbf{k W})^{* *}\end{array}$ & $\begin{array}{c}\text { Electrical } \\
\text { energy } \\
(\mathbf{k W h} / \mathbf{l})^{* * * *}\end{array}$ & $\begin{array}{c}\text { Electrical } \\
\text { energy cost } \\
\text { saving } \\
(\mathbf{R} / y)^{*}\end{array}$ \\
\hline pump & 75 & 79 & 71 & 292236 & 46086 \\
\hline pump & 250 & 263 & 237 & 975492 & 153835 \\
\hline fan & 37 & 39 & 35 & 144060 & 22718 \\
\hline fan & 37 & 39 & 35 & 144060 & 22718 \\
\hline fan & 37 & 39 & 35 & 144060 & 22718 \\
\hline Total & 436 & 459 & 413 & 1699908 & 268075 \\
\hline
\end{tabular}

* shaft power divided by 0,95 mechanical efficiency

** rated real power $\times 0,9$ utilisation factor (assumed)

*** utilized power $\times 84$ hours $\times 49$ weeks/yr

**** electrical energy $\times R 0,1577 / \mathrm{kWh}$

An energy cost saving of R 268075 per year can be achieved by switching off the three main packaged cooling towers and circulation pumps alongside the main compressor house for 84 hours per week. No expenditure is required. 
ECO 4 - Isolate areas of the plant or individual machines that do not require compressed air during non-production time

Estimated Electric Energy Conservation

Estimated Electric Energy Cost Savings

Estimated Electric Demand Reduction

Estimated Implementation Cost

Simple Payback

\author{
$1394403 \mathrm{kWh} / \mathrm{yr}$ \\ R219896/ yr \\ none \\ R40 000 \\ 0,18 years ( 2 months)
}

\section{Recommended Action}

Isolate areas of the plant or individual machines that do not require compressed air during non-production time.

\section{Background}

Base demands (see table below) from the Pascal Projects report will be used to calculate possible savings in this regard.

\begin{tabular}{|l|l|l|}
\hline \multicolumn{1}{|c|}{ Area } & $\begin{array}{c}\text { Base demand } \\
\text { (during non- } \\
\text { production) (cfm) }\end{array}$ & Isolation potential \\
\hline Paint Shop & 2182 & $\begin{array}{l}\text { will require action - } \\
\text { see ECO 2 }\end{array}$ \\
\hline Engine Plant & 181 & easily isolated \\
\hline Assembly Hall & 161 & easily isolated \\
\hline Press Shop & 3269 & easily isolated \\
\hline Toolroom & 681 & easily isolated \\
\hline Body Shop & 751 & limited isolation \\
\hline
\end{tabular}

If there were no leaks in the plant, this action would be unnecessary., but owing to the magnitude of the current air losses it is worth consideration until the leaks are repaired. During non-production time, compressed air is essential to the Press Shop (for a limited preparation period) and the Paint Mix Room (693 cfm average - Pascal Projects report). If ECO 2 - is adopted, where the paint mix room is provided with a low-pressure motor drying system then the Paint Shop (base load $2182 \mathrm{cfm}$ (PP report) could, apparently be isolated. If compressed air is essential for any valid 
processes in the paint shop during non-production time then leakage reduction should be the focus and not isolation.

\section{Anticipated savings}

Because the Press Shop draws air from the main line running through the Body Shop it may be difficult to isolate the Body Shop completely (individual feeder lines may need to be isolated).

Since the Paint Shop area will require some engineering work before it can be isolated, and because the impact of isolation will reduce as the leaks are repaired and air ceases to be misused in the Paint Shop, it has been excluded from the calculation of cost saving.

Isolation during weeknights (which should be considered) has not been included in the cost saving calculation in Table 4.

\begin{tabular}{|l|l|l|l|l|l|l|l|}
\hline Area & $\begin{array}{l}\text { Non- } \\
\text { production } \\
\text { demand } \\
\text { (cfm) }\end{array}$ & Isolation & $\begin{array}{l}\text { Non- } \\
\text { production } \\
\text { demand } \\
\text { saved }(\mathrm{cfm})\end{array}$ & $\begin{array}{l}\text { Power } \\
\text { saved } \\
(\mathrm{kW})^{*}\end{array}$ & $\begin{array}{l}\text { Hours } \\
\text { isolated } \\
\text { per week } \\
\text { *** }\end{array}$ & $\begin{array}{l}\text { Electrical } \\
\text { energy } \\
\text { saved } \\
(\mathrm{kWh} / \mathrm{yr})\end{array}$ & $\begin{array}{l}\text { Energy } \\
\text { cost } \\
\text { saving } \\
(\mathrm{R} / \mathrm{yr})\end{array}$ \\
\hline $\begin{array}{l}\text { Engine } \\
\text { Plant }\end{array}$ & 181 & yes & 181 & 30 & 54 & 78512 & 12381 \\
\hline $\begin{array}{l}\text { Assembly } \\
\text { Hall }\end{array}$ & 161 & yes & 161 & 26 & 54 & 69837 & 11013 \\
\hline $\begin{array}{l}\text { Press } \\
\text { Shop }\end{array}$ & 3269 & yes & 3269 & 536 & 30 & 787775 & 124232 \\
\hline Toolroom & 681 & yes & 681 & 112 & 54 & 295398 & 46584 \\
\hline $\begin{array}{l}\text { Body } \\
\text { Shop }\end{array}$ & 751 & half & 376 & 62 & 54 & 162881 & 25686 \\
\hline & & Totals & 4668 & 765 & & 394403 & 219896 \\
\hline
\end{tabular}

"based on the assumption that $1 \mathrm{~kW}$ is required for the compression of $6,1 \mathrm{cfm}$ to 6 bar

* 11 pm Friday to 5 am Monday. (Press Shop less 24 hrs for preparation)

* power saved $x$ isolated hours/week $\times 49$ weeks/yr

* electrical energy saved $\times$ R0, $17978 / \mathrm{kWh}$

Table 4 - Energy cost saving by compressed air isolation (Excluding Paint Shop)

Some engineering work may be required to make isolation of the various areas possible. A few valves may need to be installed or moved (to be more accessible) and some existing valves may need to be serviced. 
Costs for this action may be in the region of R40 000, which gives a simple payback period of about two months.

If the Paint Shop can be isolated, a further saving of about R63 000 per year could be achieved (base on current demand) as shown below. It has been assumed that isolation could only be achieved for 20 hours on the weekend.

\begin{tabular}{|c|c|c|c|c|c|c|c|}
\hline Area & $\begin{array}{c}\text { Non- } \\
\text { productio } \\
\text { ndemand } \\
(\mathrm{cfm})\end{array}$ & Isolation & $\begin{array}{c}\text { Non- } \\
\text { production } \\
\text { demand } \\
\text { saved } \\
\text { (cfm) }\end{array}$ & $\begin{array}{c}\text { Power } \\
\text { saved } \\
(\mathrm{kW})\end{array}$ & $\begin{array}{c}\text { Hours } \\
\text { isolated } \\
\text { per week }\end{array}$ & $\begin{array}{c}\text { Electrical } \\
\text { energy } \\
\text { saved } \\
\text { (kWh/yr) }\end{array}$ & $\begin{array}{c}\text { Energy } \\
\text { cost } \\
\text { saving } \\
\text { (R/yr) }\end{array}$ \\
\hline $\begin{array}{c}\text { Paint } \\
\text { Shop }\end{array}$ & 2182 & yes & 2182 & 358 & 20 & 350840 & $\mathbf{5 5 3 2 7}$ \\
\hline
\end{tabular}


ECO 5 - Install suitable power factor correction equipment

Projected kvar required per incomer; Incomer 1: $3490 \mathrm{kVAR}$

Incomer2: 4 284kVAR

Optimum installation ( $P F=0.991$ )

Total installed kvar recommended $Q=5500 \mathrm{kVAR}$

Estimated Electric Cost Savings $=$ R516 $690 / \mathrm{yr}$

Estimated Implementation Cost $=$ R1 007500

Simple Payback $=24$ months

Maximum installation (PF =1)

Total installed kvar recommended $Q=7700 \mathrm{kVAR}$

Estimated Electric Cost Savings $=$ R566 $320 / \mathrm{yr}$

Estimated Implementation Cost = R1 194500

Simple Payback $=26$ months

\section{Recommended Action}

Locate the source of the $5^{\text {th }}$ and $7^{\text {th }}$ voltage harmonics and filter these harmonics at the source. Potential voltage harmonic sources on site are dc and ac machine's drives and welding machines.

Install the optimum size of capacitor banks to correct for low power factor caused by the inductive loads of the motors and lamp ballasts at the two incoming lines, $11 \mathrm{kV}$ side. To ensure maximum savings, correct the power factor at the metering point, i.e., at the main substation ( $11 \mathrm{kV}$ side).

If there are plans for expansion in the near future then the maximum installation may be more suitable. Over-correction of the power factor is to be avoided.

\section{Background}

Power factor is a way of quantifying the reaction of alternating current (AC) electricity to various types of electrical loads. Inductive loads, such as motors and fluorescent lamp ballasts, cause the voltage and current to shift 
out of phase. The utility company must supply additional power, measured in kilovolt-amps (kVA), to make up for the phase shift. The total power requirement of the load is made up of two components, the resistive, or real, component and the reactive component. The resistive component, measured in kilowatts $(\mathrm{kW})$ by a wattmeter, does the useful work. The reactive component, measured in reactive kilovolt-amps (KVAR), represents the current needed to produce the magnetic field for the operation of a motor or other inductive device. This component does no useful work, is not registered on a power meter, but contributes to the heating of generators, transformers and transmission lines, constituting a loss for the utility company.

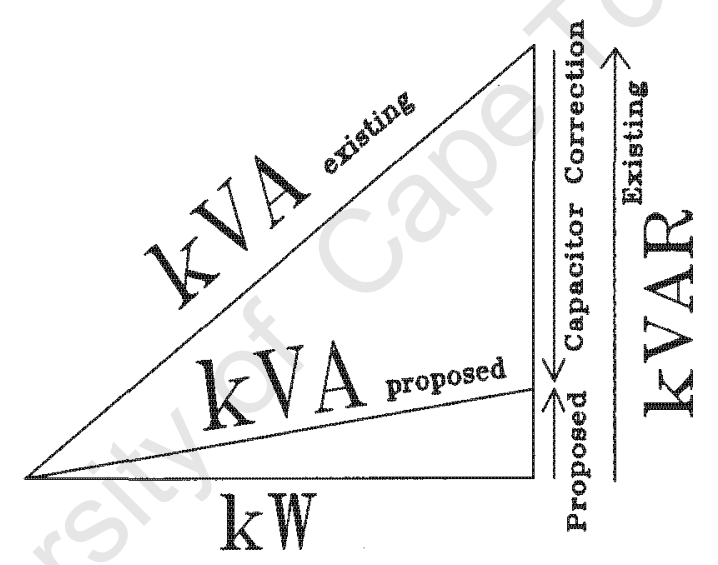

Components of Electrical Power

The ratio of real, useable power ( $k W$ ) to apparent power (kVA) is known as the power factor. To reduce reactive losses, the user should increase the power factor to a value as close to unity $(1.0)$ as is practical for the entire manufacturing plant. For example, assume that a manufacturing plant has an average annual power factor of 0.78 . Power factor of 0.78 means that for every $78 \mathrm{~kW}$ of usable power that the plant requires, the utility must supply $78 \mathrm{~kW} / \mathrm{PF}$ or $100 \mathrm{kVA}$. If the plant's power factor is changed from 0.78 to 0.95 , then for every $78 \mathrm{~kW}$ required by the plant, the utility need only supply $78 \mathrm{~kW} / 0.95$ or $82 \mathrm{kVA}$. 
Capacitor banks can be installed to decrease the reactive power (KVAR) and thus the apparent power. Capacitors draw current, which leads the voltage, while inductive loads draw current, which lags the voltage. The net result is that the current in the supply line is brought more closely in phase with the supply voltage. A power factor of 1,0 indicates that the current and the voltage are exactly in phase. It is not always economical to install PFC equipment with an aim of unity power factor.

Capacitors can be installed at any point in the electrical system and will improve the power factor between the point of application and the power source. Capacitors can be added at each piece of equipment, ahead of groups of small motors, or at main services. The advantages and disadvantages of each type of installation are highlighted in Table 5 below.

\begin{tabular}{|c|c|c|}
\hline $\begin{array}{c}\text { Type of } \\
\text { Capacitor } \\
\text { Installation }\end{array}$ & Advantages & \multicolumn{1}{|c|}{ Disadvantages } \\
\hline $\begin{array}{c}\text { 1. Individual } \\
\text { Equipment } \\
\begin{array}{c}\text { (e.g. individual } \\
\text { induction motors) }\end{array}\end{array}$ & $\begin{array}{c}\text { Increased load } \\
\text { capabilities of } \\
\text { distribution system } \\
\text { Better voltage } \\
\text { regulation }\end{array}$ & $\begin{array}{l}\text { Smaller capacitors cost more per kVAR } \\
\text { than larger units } \\
\text { Heavy on maintenance and monitoring } \\
\text { Possible high failure rate }\end{array}$ \\
\hline $\begin{array}{c}\text { 2. Grouped } \\
\text { Equipment }\end{array}$ & $\begin{array}{c}\text { Increased load } \\
\text { capabilities of the } \\
\text { service }\end{array}$ & $\begin{array}{l}\text { Switching means may be required to control } \\
\text { the amount of capacitance used } \\
\text { Heavy on maintenance and monitoring }\end{array}$ \\
\hline $\begin{array}{l}\text { 3. Main Service } \\
\text { (Main substation, } \\
\text { Incomer 1 and 2) }\end{array}$ & $\begin{array}{c}\text { Low installation costs } \\
\text { Low maintenance costs }\end{array}$ & $\begin{array}{l}\text { Switching means will usually be required to } \\
\text { control the amount of capacitance used } \\
\text { Does not improve load capabilities of } \\
\text { distribution system }\end{array}$ \\
\hline
\end{tabular}

Table 5 - Options for capacitor installation

The primary objective is to reduce the peak demand thereby saving on the electricity bill, although the energy component is not changed. Initial installation ( 3 in table 11), is very costly on the equipment side, but reduced maintenance, installation and monitoring offset this initial cost in the medium to long term. 


\section{Anticipated Savings}

The cost for this analysis are based on the following breakdown:

PFC equipment: $\quad$ R85 000/MVAR

Capacitor bank breakers: R90 000/ breaker

Reactors/ Filters: R100 000/ MVAR

It is assumed that three capacitor banks will be required for each of the two incomers (six breakers in total).

Table 6 (following page) shows the effect that capacitance (KVAR) will have on this plant's power factor, for the maximum and optimum scenarios. The table shows the measured demand, power factor and the cost savings to be expected by adding correction equipment (KVAR). 


\begin{tabular}{|c|c|c|c|c|c|c|}
\hline \multicolumn{5}{|c|}{ Current conditions } & \multicolumn{2}{|c|}{ Proposed power factor } \\
\hline \multirow[b]{3}{*}{ Month } & \multicolumn{3}{|c|}{ Measured Measured Calculated } & \multirow{3}{*}{$\begin{array}{l}\text { Excess } \\
\text { KVAR } \\
\end{array}$} & \multirow{2}{*}{\multicolumn{2}{|c|}{ Proposed kVAR Correction }} \\
\hline & \multirow{2}{*}{$\begin{array}{c}\text { Demand } \\
\text { [kVA] }\end{array}$} & \multirow{2}{*}{$\begin{array}{c}\text { Power } \\
{[\mathrm{kW}]}\end{array}$} & \multirow{2}{*}{$\begin{array}{l}\text { Power } \\
\text { Factor }\end{array}$} & & & \\
\hline & & & & & 5500 & 7700 \\
\hline January & 17568 & 15990 & 0,910 & 7276 & 0,994 & 1,000 \\
\hline February & 18076 & 16298 & 0,902 & 7817 & 0,990 & 1,000 \\
\hline March & 18323 & 16482 & 0,900 & 8004 & 0,989 & 1,000 \\
\hline April & 21632 & 19964 & 0,923 & 8329 & 0,990 & 1,000 \\
\hline May & 17063 & 15526 & 0,910 & 7077 & 0,995 & 0,999 \\
\hline June & -19672 & 17926 & 0,911 & 8102 & 0,990 & 1,000 \\
\hline Wuly & 18098 & 16312 & 0,901 & 7839 & 0,990 & 1,000 \\
\hline August & 17694 & 15908 & 0,899 & 7746 & 0,990 & 1,000 \\
\hline September & 17591 & 15682 & 0,891 & 7969 & 0,988 & 1,000 \\
\hline October & 17212 & 15380 & 0,894 & 7727 & 0,990 & 1,000 \\
\hline November & 16662 & 14891 & 0,894 & 7474 & 0,991 & 1,000 \\
\hline December & 17764 & 16019 & 0,902 & 7677 & 0,991 & 1,000 \\
\hline \multicolumn{7}{|c|}{ Savings projected } \\
\hline & \multicolumn{3}{|c|}{ Measured Measured Calculated } & & \multirow{3}{*}{$\begin{array}{c}\text { Savings per } \\
\text { month } \\
5500\end{array}$} & \multirow{3}{*}{$\begin{array}{c}\text { Savings } \\
\text { per month } \\
7700 \\
\end{array}$} \\
\hline & \multirow{2}{*}{$\begin{array}{c}\text { Demand } \\
{[\mathrm{kVA}]}\end{array}$} & \multirow{2}{*}{$\begin{array}{l}\text { Power } \\
{[\mathrm{kW}]}\end{array}$} & \multirow{2}{*}{$\begin{array}{l}\text { Power } \\
\text { Factor } \\
\end{array}$} & & & \\
\hline & & & & & & \\
\hline January & 17568 & 15990 & 0,910 & & R 40022 & R 42533 \\
\hline February & 18076 & 16298 & 0,902 & & $R 43659$ & $R 48083$ \\
\hline March & 18323 & 16482 & 0,900 & & $R 44680$ & R 49722 \\
\hline April & 21632 & 19964 & 0,923 & & R 39722 & R 44850 \\
\hline May & 17063 & 15526 & 0,910 & & R 39413 & $R 41238$ \\
\hline June & 19672 & 17926 & 0,911 & & $R 42146$ & R 47107 \\
\hline July & 18098 & 16312 & 0,901 & & $R 43796$ & R 48295 \\
\hline August & 17694 & 15908 & 0,899 & & R 44040 & R 48309 \\
\hline September & 17591 & 15682 & 0,891 & & $R 46409$ & R 51575 \\
\hline October & 17212 & 15380 & 0,894 & & $R 45216$ & R49554 \\
\hline November & 16662 & 14891 & 0,894 & & $R 44372$ & $R 47853$ \\
\hline \multirow[t]{3}{*}{ December } & 17764 & 16019 & 0,902 & & R 43211 & R 47195 \\
\hline & & \multirow{2}{*}{\multicolumn{3}{|c|}{$\begin{array}{l}\text { Avarage savings/ month } \\
\text { Total savings/ } \\
\text { year }\end{array}$}} & R 43057 & R 47193 \\
\hline & & & & & R 516691 & R 566320 \\
\hline
\end{tabular}

Table6: Maximum demand savings through power factor correction

\section{Implementation Cost}

As calculated in Table 12, the installation of capacitors rated at 5500 and

7700 kVAR would be required to correct for low power factor, optimally and to unity respectively. The installed cost for capacitors is estimated as R85 000/MVAR, which leads to an implementation cost of R1 007500 and R1 194500 . Thus, the annual cost savings of R516 600/yr and R566 320/yr 
would pay for the implementation cost in 24 and 26 months, respectively. The costs of filter banks that may be needed on sight are excluded in these calculations, because the sources is unknown, Therefore it is difficult to estimate how much filtering is needed. Furthermore, the cost of installation cannot be estimated at this stage, because, civil work and re-cabling may be required on the main substation to accommodate the capacitor banks.

Notes

1. The determination of the optimum power factor correction and the installation of the capacitors may require additional engineering. We recommend that additional professional advice be obtained from a capacitor supplier, electrical contractor, or an engineering firm.

2. Following a site visit, $S$ Khumalo reported that the capacitor banks in 30 out of 32 substations, were not in good working condition. His impression was that many of the capacitor banks were inoperative - possibly damaged from harmonics in the supply voltage or increased load since installation.

3. There are additional benefits from improving power factor. Less total current flows in the plant wiring, motors, and other equipment. Less current means reduced power losses with resulting energy and demand savings. However, energy savings caused by these power losses are typically less than $1 \%$ of plant electricity use.

4. Other benefits from improved power factor are that motors run cooler and that system voltage is higher. Therefore, motor efficiency, capacity, and starting torque will also be slightly higher. Branch circuit capacity also is higher because more real work can be done with the same total current.

5. If automatic controllers are used, the response time is important for rapid power factor variations. 
ECO 6 - Use waste heat to heat phosphate bath

$\begin{array}{ll}\text { Estimated electrical energy saving: } & R 190000 / \text { year } \\ \text { Estimated installation cost: } & \text { R } 300000 \\ \text { Payback period: } & 1,58 \text { years }\end{array}$

Recommended Action

Install liquid-cooled condensers to Electrocoat chillers. The additional condensers are to be installed in parallel with the factory supplied aircooled condensers such that the liquid-cooled units have priority.

\section{Background}

Two large Carrier air-cooled water chillers currently provide cooling to the Electrocoat bath. The energy removed is discarded to atmosphere via the air-cooled condensers. Liquid-cooled condensers can be installed in parallel to the air-cooled ones such that they provide "free heat" to the phosphate bath instead of the cost of the present thermic oil/HFO arrangement. The plate heat exchanger between the thermic oil and the water circuit used to heat the phosphate bath is rated at $1000 \mathrm{~kW}$.

\section{Anticipated Savings}

The cost of heating using HFO on this site is about R0,14/kWh at $100 \%$ efficiency. If we assume that the maximum system efficiency to the point of delivery of heat into the phosphate tank is about $75 \%$, then the cost of "useful" HFO produced energy is about R0,19/kWh.

The cooling requirement of the Electrocoat bath is $420 \mathrm{~kW}$, which makes each chiller capable of rejecting at least $500 \mathrm{~kW}$ ( $420 \mathrm{~kW}$ plus compressor power). Based on a coincident heating/cooling requirement of 3 hours per day for seven day week and 49 weeks in the year, the annual "free energy" would be about $500000 \mathrm{kWh}$. This amounts to an avoided HFO heating cost of at least R 95000 / year per chiller (68 000 litres HFO/year/chiller), provided the heating and cooling needs are coincident. 
The total anticipated energy saving from installing two chillers is R190 000 per year.

Implementation Costs

The cost of the conversion would be about R 150000 for each of the two chillers - giving a total cost for conversion of R300 000. With an anticipated saving of $R 190000$ this results in a payback period of 1,58 years (19 months).

It is recommended that further observation be carried out to determine whether the loads are sufficiently coincidental. 
ECO 7 - Install High-Efficiency Lighting

\begin{tabular}{|c|c|}
\hline Estimated Electric Energy Savings: & $2410244 \mathrm{kWh} / \mathrm{yr}$ \\
\hline Estimated Electric Energy Cost Savings: & R $433314 / y r$ \\
\hline Estimated Electric Demand Savings: & $3301 \mathrm{~kW} / \mathrm{yr}$ \\
\hline Estimated Electric Demand Cost Savings: & $\mathrm{R} 118772 / \mathrm{yr}$ \\
\hline Estimated Total Cost Savings: & R $239473 / y r$ \\
\hline Estimated Implementation Cost: & $R 726936$ \\
\hline Simple Payback Period: & 3,0 years \\
\hline
\end{tabular}

\section{Recommended Action}

The existing mercury vapor (MV) lamps (400W) and a few high pressure sodium (HPS) lamps (400W) should be replaced with metal halide (MH) lamps (250W) including new ballasts and igniters. MH lamps (250W) use less energy than MV (400W) and HPS (400W) with a comparable light output to the 400W MV.

\section{Background}

The focus of this investigation is the bay lighting. The bay lighting mainly consists of MV lamps, however, there are also a few HPS lamps installed. Each lamp has $400 \mathrm{~W}$. The total number of fittings adds up to approximately 1728 (Machining Hall: 265, Assembly Hall: 506, Press Shop: 231, Body Shop: 201, Pressed Part Warehouse: 212 and Container Warehouse: 193, Steel and Heavy Tool Store: 120). Moreover many lights are burned out and have not been replaced.

In general the arrangement of the lights in the separate parts of the plant as well as the measured lux levels are not as recommended by the South Africa Bureau of Standards (SABS). According to the SABS the recommended lighting level of the Body Shop, Press Shop, Steel and Heavy Tool Store, Paint Shop and the Final Assembly is 400 lux and recommended lighting level of the Warehouses is 160 lux. The measured lighting levels are shown in Appendix $C$. 
For calculation purposes, it has been assumed that current lighting levels are acceptable to $\mathrm{VW}$. Thus the methodology was to keep the lux level constant while choosing lamps with the same lumen output and a preferably better Colour Rendering Index (CRI).

Higher efficiency lighting has been a focus for many lighting manufacturers in recent years. New technology has led to innovative lamps that have a longer rated life and require less wattage with a minimal reduction in overall lumen output. Most of these lamps were designed as direct replacements for the old inefficient lamps, so the existing fixtures can be used in most cases. However, this investigation came to the conclusion that the existing fixtures can only be used for the $400 \mathrm{~W} \mathrm{MV}$ and $400 \mathrm{~W}$ HPS and not for the proposed $250 \mathrm{~W}$ MH lamps. Hence the up front cost for a new fitting or the replacement of the existing ballast and the igniter had to be taken into account. Ideally the installed lamps should have been replaced with $400 \mathrm{~W}$ MH lamps because of the increased lumen output and overall improvement of the lighting situation in the plant. However, this would have resulted in a completely new refurnishing including delamping and rewiring which unfortunately exceeds the scope of this ECO.

\section{High Intensity Discharge Lighting (HID)}

The appropriate use of HID lamps, which include metal halide (MH), mercury vapor (MV), and low and high-pressure sodium (HPS), is dependent on several factors. When choosing an HID replacement lamp the application of the lamp will ultimately determine its suitability. For example, in areas where color differentiation is important the use of a HPS lamp may not be feasible due to its low CRI value. In our study we assumed that the CRI is also of greater importance because for most production processes it is important to clearly differentiate colors. The efficacy values of the most common lamp types are shown in Table 7 (following page). The efficacy of a lamp is a measure of the lamp's ability to convert electrical power into visible light. The 
quantity of light emitted (lumen output) is divided by the input power of the lamp to determine the lamp's efficacy and is a measure of energy efficiency expressed in Lumens per Watt or LPW. A listing of efficacies, CRIs, and lamp life for HID lighting is shown in the following table.

\begin{tabular}{|c|c|c|c|c|c|c|c|c|}
\hline & $\begin{array}{c}\text { Standard } \\
\text { incandes- } \\
\text { cent }\end{array}$ & $\begin{array}{l}\text { Tungsten } \\
\text { halogen }\end{array}$ & Flourescent & $\begin{array}{l}\text { Compact } \\
\text { fourescent }\end{array}$ & $\begin{array}{l}\text { Mercury } \\
\text { vapour }\end{array}$ & $\begin{array}{l}\text { Metal } \\
\text { halide }\end{array}$ & $\begin{array}{l}\text { High } \\
\text { pressure } \\
\text { sodium }\end{array}$ & $\begin{array}{l}\text { Low } \\
\text { pressure } \\
\text { sodium }\end{array}$ \\
\hline Watts & $3-1500$ & $10-1500$ & $4-215$ & $4-55$ & $\begin{array}{c}40-1 \\
250\end{array}$ & $\begin{array}{c}32- \\
2000\end{array}$ & $\begin{array}{c}35 \% \\
1000\end{array}$ & $18-180$ \\
\hline $\begin{array}{l}\text { Average system } \\
\text { efficacy }(\mathrm{m} M)\end{array}$ & $4-24$ & $8 \cdot 33$ & $49 \cdot 89$ & $24-68$ & $19-43$ & $53-115$ & $53 \cdot 147$ & $50-150$ \\
\hline $\begin{array}{l}\text { Average rated } \\
\text { life (hours) }\end{array}$ & $750-2000$ & $\begin{array}{c}2000= \\
4000\end{array}$ & $\begin{array}{l}7500 \\
24000\end{array}$ & $\begin{array}{l}7000- \\
20000\end{array}$ & $\begin{array}{l}16000 \\
24000\end{array}$ & $\begin{array}{l}6000- \\
20000\end{array}$ & $\begin{array}{c}16000= \\
24000\end{array}$ & $\begin{array}{l}12000- \\
18000\end{array}$ \\
\hline $\mathrm{CRI}$ & 100 & 100 & $49 \cdot 92$ & $82-86$ & $15-50$ & $65-92$ & $21 \cdot 85$ & $0^{(1)}$ \\
\hline Life cycle cost & high & high & low & $\bmod$ & $\bmod$ & $\bmod$ & low & low \\
\hline Fixture size & compact & compact & extended & compact & compact & compact & compact & extended \\
\hline $\begin{array}{l}\text { Start to full } \\
\text { brightness }\end{array}$ & immed & immed & $5 \mathrm{sec}$ & $0-1 \mathrm{~min}$ & $3.9 \mathrm{~min}$ & $\begin{array}{l}3-5 \\
\min \end{array}$ & $3-4 \min$ & $7-9 \mathrm{~min}$ \\
\hline Restrike tme & immed & immed & inmed & immed & $\begin{array}{c}10-20 \\
\min \end{array}$ & $\begin{array}{c}4-20 \\
\min \\
\end{array}$ & $1 \mathrm{~min}$ & immed \\
\hline $\begin{array}{l}\text { Lumen } \\
\text { maintenance }\end{array}$ & $\begin{array}{c}\text { good/excell } \\
\text { ent }\end{array}$ & excellent & $\begin{array}{c}\text { fair / } \\
\text { excellent }\end{array}$ & $\begin{array}{c}\text { good / } \\
\text { excellent }\end{array}$ & poor / fair & good & $\begin{array}{c}\text { goodl } \\
\text { excellent }\end{array}$ & excellent \\
\hline
\end{tabular}

Table 7: Lamp Characteristics (Source: International Industrial Assessment Centre)

Because use of HID lamps is so common in industry, progress is constantly being made toward higher efficiency. This results in fewer fixtures needed, less energy consumed, and reduced maintenance costs.

Lighting fixture specifications, and costs are given in Table 8 (following page). The prices indicate the retail cost of lamps available in South Afirca. 


\begin{tabular}{|c|c|c|c|}
\hline $\begin{array}{c}\text { Lamp/Ballast/lgniter/ Fixture } \\
\text { Description }\end{array}$ & $\begin{array}{l}\text { Lamp } \\
\text { Code }\end{array}$ & $\begin{array}{c}\text { Cost of new } \\
\text { equipment } \\
R \text { (incl. VAT) }\end{array}$ & $\begin{array}{l}\text { Lamp } \\
\text { Type }\end{array}$ \\
\hline $\begin{array}{c}\text { Lamp } \\
\text { Ballast } \\
\text { Igniter } \\
\text { Fixture + Lamp }\end{array}$ & $\begin{array}{l}400 \mathrm{~W} \\
400 \mathrm{~W} \\
400 \mathrm{~W} \\
400 \mathrm{~W}\end{array}$ & $\begin{array}{r}88 \\
133 \\
98 \\
444 \\
\end{array}$ & $\begin{array}{l}\text { Mercury Vapor } \\
\text { Mercury Vapor } \\
\text { Mercury Vapor } \\
\text { Mercury Vapor }\end{array}$ \\
\hline $\begin{array}{c}\text { Lamp } \\
\text { Ballast } \\
\text { Igniter } \\
\text { Fixture + Lamp }\end{array}$ & $\begin{array}{l}250 \mathrm{~W} \\
250 \mathrm{~W} \\
250 \mathrm{~W} \\
250 \mathrm{~W}\end{array}$ & $\begin{array}{r}99 \\
150 \\
98 \\
747\end{array}$ & $\begin{array}{l}\text { High Pressure } \\
\text { Sodium } \\
\text { High Pressure } \\
\text { Sodium } \\
\text { High Pressure } \\
\text { Sodium } \\
\text { High Pressure } \\
\text { Sodium }\end{array}$ \\
\hline $\begin{array}{c}\text { Lamp } \\
\text { Ballast } \\
\text { Igniter } \\
\text { Fixture + Lamp }\end{array}$ & $\begin{array}{l}400 \mathrm{~W} \\
400 \mathrm{~W} \\
400 \mathrm{~W} \\
400 \mathrm{~W}\end{array}$ & $\begin{array}{r}114 \\
184 \\
98 \\
762 \\
\end{array}$ & $\begin{array}{c}\text { High Pressure } \\
\text { Sodium } \\
\text { High Pressure } \\
\text { Sodium } \\
\text { High Pressure } \\
\text { Sodium } \\
\text { High Pressure } \\
\text { Sodium } \\
\end{array}$ \\
\hline $\begin{array}{c}\text { Lamp } \\
\text { Ballast } \\
\text { Igniter } \\
\text { Fixture + Lamp }\end{array}$ & $\begin{array}{l}250 \mathrm{~W} \\
250 \mathrm{~W} \\
250 \mathrm{~W} \\
250 \mathrm{~W}\end{array}$ & $\begin{array}{r}244 \\
126 \\
98 \\
935 \\
\end{array}$ & $\begin{array}{l}\text { Metal Halide } \\
\text { Metal Halide } \\
\text { Metal Halide } \\
\text { Metal Halide }\end{array}$ \\
\hline $\begin{array}{c}\text { Lamp } \\
\text { Ballast } \\
\text { Igniter } \\
\text { Fixture + Lamp }\end{array}$ & $\begin{array}{l}400 \mathrm{~W} \\
400 \mathrm{~W} \\
400 \mathrm{~W} \\
400 \mathrm{~W}\end{array}$ & $\begin{array}{r}249 \\
149 \\
98 \\
941\end{array}$ & $\begin{array}{l}\text { Metal Halide } \\
\text { Metal Halide } \\
\text { Metal Halide } \\
\text { Metal Halide }\end{array}$ \\
\hline
\end{tabular}

Table 8 - Lighting fixture specifications, and costs 


\section{Anticipated Savings}

Tables 9, 10 and 11, supported by calculations in Appendix D, provide the existing and proposed lighting scenario as determined from the lighting survey conducted during the facility visit, and the energy conservation, demand reduction, and cost savings for lamp/ballast combinations in the other plant areas.

\begin{tabular}{|c|c|c|c|c|c|c|c|c|c|}
\hline Building Area & $\begin{array}{c}\text { Existing } \\
\text { ballast } \\
\text { llamp } \\
\text { Code }\end{array}$ & $\begin{array}{l}\text { Avg. } \\
\text { light } \\
\text { level } \\
\text { fc }\end{array}$ & $\begin{array}{c}\text { Existing } \\
\text { ballast /amp } \\
\text { Description }\end{array}$ & $\begin{array}{l}\text { No. of } \\
\text { fixtures }\end{array}$ & $\begin{array}{c}\text { Fixture } \\
\text { power } \\
W\end{array}$ & $\begin{array}{c}\text { Total power } \\
W\end{array}$ & $\begin{array}{l}\text { Annual } \\
\text { average } \\
\text { demand } \\
\text { kW/yr }\end{array}$ & $\begin{array}{l}\text { Usage } \\
\text { time } \\
h / y r\end{array}$ & $\begin{array}{c}\text { Total Energy } \\
\text { Usage } \\
k W h / y r\end{array}$ \\
\hline $\begin{array}{l}\text { Machining } \\
\text { Hall } \\
\text { Machining }\end{array}$ & 73 & 20 & $400 \mathrm{~W}$ MV & 260 & 454 & 118040 & 1416,5 & 8760 & 1034030 \\
\hline $\begin{array}{l}\text { Hall } \\
\text { Pressed Part }\end{array}$ & 85 & 20 & 400W HPS & 5 & 457 & 2285 & 27,4 & 8760 & 20017 \\
\hline & 73 & 30 & 400W MV & 184 & 454 & 83536 & 1002,4 & 8760 & 731775 \\
\hline $\begin{array}{l}\text { Warehouse } \\
\text { Container }\end{array}$ & 85 & 30 & 400W HPS & 28 & 457 & 12796 & 153,6 & 8760 & 112093 \\
\hline $\begin{array}{l}\text { Warehouse } \\
\text { Container }\end{array}$ & 73 & 26 & $400 \mathrm{~W} M$ & 134 & 454 & 60836 & 730,0 & 8760 & 532923 \\
\hline Warehouse & 85 & 26 & 400W HPS & 59 & 457 & 26963 & 323,6 & 8760 & 236196 \\
\hline Press Shop & 73 & 69 & 400W MV & 231 & 454 & 104874 & 1258,5 & 8760 & 918696 \\
\hline Body Shop & 73 & 23 & 400W MV & 190 & 454 & 86260 & 1035,1 & 8760 & 755638 \\
\hline Body Shop & 85 & 23 & 400W HPS & 11 & 457 & 5027 & 60,3 & 8760 & 44037 \\
\hline Assembly Hall & 73 & 27 & 400W MV & 479 & 454 & 217466 & 2609,6 & 8760 & 1905002 \\
\hline $\begin{array}{l}\text { Assembly Hall } \\
\text { Steel and } \\
\text { Heavy Tool } \\
\text { Store }\end{array}$ & 73 & 35 & $\begin{array}{l}\text { 400W HPS } \\
\text { 400W MV }\end{array}$ & 120 & 454 & 12339 & 148,1 & 8760 & 108090 \\
\hline Total & & 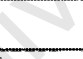 & & 1728 & & 784902 & 9418,8 & & 6875742 \\
\hline
\end{tabular}

$100 \%$ coincidence factor was used in this table

Table 9 - Existing Lamp Situation: 


\begin{tabular}{|c|c|c|c|c|c|c|c|c|}
\hline Building Area & $\begin{array}{c}\text { Existng } \\
\text { ballast } \\
\text { lamp } \\
\text { code }\end{array}$ & \begin{tabular}{|c|} 
Existing \\
ballast/lamp \\
description
\end{tabular} & $\begin{array}{l}\text { Percent } \\
\text { existing } \\
\text { lumen } \\
\text { output }\end{array}$ & $\begin{array}{c}\text { No. } \\
\text { of } \\
\text { fixtures }\end{array}$ & $\begin{array}{c}\text { Fixture } \\
\text { power } \\
W\end{array}$ & $\begin{array}{c}\text { Total } \\
\text { power } \\
W\end{array}$ & $\begin{array}{c}\text { Annual } \\
\text { average } \\
\text { demand } \\
k W / y r\end{array}$ & $\begin{array}{l}\text { Total energy } \\
\text { usage } k W h / y r\end{array}$ \\
\hline $\begin{array}{l}\text { Machining } \\
\text { Hall } \\
\text { Machining }\end{array}$ & 93 & $250 \mathrm{WMH}$ & 96 & 260 & 295 & 76700 & 920,4 & 671892 \\
\hline $\begin{array}{l}\text { Hall } \\
\text { Pressed Part }\end{array}$ & 93 & $250 \mathrm{WMH}$ & 42 & 5 & 295 & 1475 & 17,7 & 12921 \\
\hline $\begin{array}{l}\text { Warehouse } \\
\text { Pressed Part }\end{array}$ & 93 & $250 \mathrm{WMH}$ & 96 & 184 & 295 & 54280 & 651,4 & 475493 \\
\hline $\begin{array}{l}\text { Warehouse } \\
\text { Container }\end{array}$ & 93 & $250 \mathrm{WMH}$ & 42 & 28 & 295 & 8260 & 99,1 & 72358 \\
\hline $\begin{array}{l}\text { Warehouse } \\
\text { Container }\end{array}$ & 93 & $250 \mathrm{WMH}$ & 96 & 134 & 295 & 39530 & 474,4 & 346283 \\
\hline Warehouse & 93 & $250 \mathrm{WMH}$ & 42 & 59 & 295 & 17405 & 208,9 & 152468 \\
\hline Press Shop & 93 & 250W MH & 96 & 231 & 295 & 68145 & 817,7 & 596950 \\
\hline Body Shop & 93 & 250W MH & 96 & 190 & 295 & 56050 & 672,6 & 490998 \\
\hline $\begin{array}{l}\text { Body Shop } \\
\text { Assembly }\end{array}$ & 93 & $250 \mathrm{WMH}$ & 42 & 11 & 295 & 3245 & 38,9 & 28426 \\
\hline $\begin{array}{l}\text { Hall } \\
\text { Assembly }\end{array}$ & 93 & $250 \mathrm{WMH}$ & 96 & 479 & 295 & 141305 & 1695,7 & 1237832 \\
\hline $\begin{array}{l}\text { Hall } \\
\text { Steel and }\end{array}$ & 93 & 250W MH & 42 & 27 & 295 & 7965 & 95,6 & 69773 \\
\hline $\begin{array}{l}\text { Heavy Tool } \\
\text { Store }\end{array}$ & 93 & 250W MH & 96 & 120 & 295 & 35400 & 424,8 & 310104 \\
\hline TOTALS & 93 & & & 1728 & & 509760 & 6117,1 & 4465498 \\
\hline
\end{tabular}

Table 10 - Proposed lamp situation

\begin{tabular}{|c|c|c|c|c|c|c|}
\hline Building Area & $\begin{array}{c}\text { Energy } \\
\text { Conservation } \\
k W h / y r\end{array}$ & $\begin{array}{c}\text { Demand } \\
\text { Reduction } \\
k W / y r\end{array}$ & $\begin{array}{c}\text { Energy } \\
\text { Cost } \\
\text { Savings } \\
\text { Ryr }\end{array}$ & $\begin{array}{c}\text { Demand } \\
\text { Cost } \\
\text { Savings } \\
\text { R/yr }\end{array}$ & $\begin{array}{c}\text { Lamp } \\
\text { Replacement } \\
\text { Cost } \\
\text { Savings } \\
\text { R/yr }\end{array}$ & $\begin{array}{c}\text { Total Cosi } \\
\text { Savings } \\
\text { Ryyr }\end{array}$ \\
\hline Machining Hall & 362138 & 496,1 & 65105 & 17845 & -47222 & 35728 \\
\hline Machining Hall & 7096 & 9,7 & 1276 & 350 & -861 & 765 \\
\hline Pressed Part Warehouse & 256283 & 351,1 & 46074 & 12629 & -33419 & 25285 \\
\hline Pressed Part Warehouse & 39735 & 54,4 & 7144 & 1958 & -4829 & 4282 \\
\hline Container Warehouse & 186641 & 255,7 & 33554 & 9197 & -24338 & 18414 \\
\hline Conte & 83728 & 114,7 & 15053 & 4126 & -10156 & 9023 \\
\hline Press Shop & 321746 & 440,7 & 57844 & 15855 & -41955 & 31743 \\
\hline Body Shop & 264640 & 362,5 & 47577 & 13041 & -34509 & 26109 \\
\hline Body Shop & 15610 & 21,4 & 2806 & 769 & -1893 & 1682 \\
\hline Assembly Hall & 667170 & 913,9 & 119944 & 32877 & -86998 & 65823 \\
\hline Assembly Hall & 38316 & 52,5 & 6888 & 1888 & -4648 & 4129 \\
\hline $\begin{array}{l}\text { Steel and Heavy Tool } \\
\text { Store }\end{array}$ & 167141 & 229,0 & 30049 & 8236 & -21795 & 16490 \\
\hline TOTALS & 2410244 & 3301,7 & 433314 & 118772 & -312613 & 239473 \\
\hline
\end{tabular}

Table 11 - Annual Savings through high efficiency lighting 
From the previous tables, the total estimated energy savings is 2410244

$\mathrm{kWh} / \mathrm{yr}$, and the estimated demand savings are $3301 \mathrm{~kW} / \mathrm{yr}$. Total cost savings are R 239 473/yr.

Implementation Costs:

The implementation cost for this recommendation includes the equipment and labor costs required for the new lamps, ballasts and igniters. Labor costs are estimated as $R 50$ per fixture. Table 12 below, again supported by calculations in Appendix D, summarizes the total cost savings, estimated implementation cost, and simple payback period for each area of the facility.

\begin{tabular}{|c|c|c|c|c|c|c|c|}
\hline Building Area & $\begin{array}{c}\text { Total cost } \\
\text { savings } \\
\text { per year } \\
\mathrm{R}\end{array}$ & $\begin{array}{c}\text { Total lamp } \\
\text { cosis } \\
R\end{array}$ & $\begin{array}{c}\text { Total } \\
\text { ballast } \\
\text { costs } \\
R\end{array}$ & $\begin{array}{c}\text { Total } \\
\text { igniter } \\
\text { costs } \\
R \\
\end{array}$ & $\begin{array}{c}\text { Total } \\
\text { labour } \\
\text { costs } \\
\mathrm{R}\end{array}$ & $\begin{array}{c}\text { Total } \\
\text { implemen } \\
\text {-tation costs } \\
\mathrm{R}\end{array}$ & $\begin{array}{c}\text { Simple } \\
\text { payback } \\
\text { (years) }\end{array}$ \\
\hline Machining Hall & 35728 & 63440 & 32760 & 98 & 13000 & 109298 & 3,1 \\
\hline $\begin{array}{l}\text { Machining Hall } \\
\text { Pressed Part }\end{array}$ & 765 & 1220 & 630 & 98 & 250 & 2198 & 2,9 \\
\hline $\begin{array}{l}\text { Warehouse } \\
\text { Pressed Part }\end{array}$ & 25285 & 44896 & 23184 & 98 & 9200 & 77378 & 3,1 \\
\hline $\begin{array}{l}\text { Warehouse } \\
\text { Container }\end{array}$ & 4282 & 6832 & 3528 & 98 & 1400 & 11858 & 2,8 \\
\hline $\begin{array}{l}\text { Warehouse } \\
\text { Container }\end{array}$ & 18414 & 32696 & 16884 & 98 & 6700 & 56378 & 3,1 \\
\hline Warehouse & 9023 & 14396 & 7434 & 98 & 2950 & 24878 & 2,8 \\
\hline Press Shop & 31743 & 56364 & 29106 & 98 & 11550 & 97118 & 3,1 \\
\hline Body Shop & 26109 & 46360 & 23940 & 98 & 9500 & 79898 & 3,1 \\
\hline Body Shop & 1682 & 2684 & 1386 & 98 & 550 & 4718 & 2,8 \\
\hline Assembly Hall & 65823 & 116876 & 60354 & 98 & 23950 & 201278 & 3,1 \\
\hline $\begin{array}{l}\text { Assembly Hall } \\
\text { Steel and Heavy }\end{array}$ & 4129 & 6588 & 3402 & 98 & 1350 & 11438 & 2,8 \\
\hline Tool Store & 16490 & 29280 & 15120 & 98 & 6000 & 50498 & 3,1 \\
\hline TOTALS & 239473 & 421632 & 217728 & 1176 & 86400 & 726936 & 3,0 \\
\hline
\end{tabular}

Table 12 - Costs and savings for high efficiency lighting

From the table, the total estimated implementation cost is $R 726936$. The cost savings of R 239473 / year would pay for the implementation cost in 3,0 years. 
The energy savings, cost savings and implementation costs presented in this analysis are based upon total replacement of all applicable fixtures in the facility at once. This would be the case if a facility has sufficient capital, loans or other funding available for implementation. This method would result in a large and immediate energy savings, but would require a large initial investment. Several options are available to spread out this investment, including spot relamping and group re-lamping. An analysis of spot relamping and group relamping options with incremental costs and savings is in APPENDIXE. 
ECO 8 - Turn off bay lights during non-production hours

\author{
Estimated Electric Energy Savings: $\quad 2672657 \mathrm{kWh} /$ year \\ Estimated Electric Energy Cost Savings: R 480490 /year \\ Estimated Total Cost Savings: $\quad$ R 446190 / year \\ Payback Period: No capital costs. Labour costs included in \\ estimated
}

total cost savings.

\title{
Recommended Action:
}

The bay lights can be turned off during non-production hours such as during the Christmas break and especially during the night.

\section{Background:}

The bay lighting mainly consists of Mercury Vapor (MV) lamps, however, there are also a few High Pressure Sodium (HPS) lamps installed. Each lamp is rated at $400 \mathrm{~W}$. The total number of fittings adds up to approximately 1728 (Machining Hall: 265, Assembly Hall: 506, Press Shop: 231, Body Shop: 201, Pressed Part Warehouse: 212, Container Warehouse: 193, and the Steel and Heavy Tool Store: 120). These lamps are unnecessarily left on during non-production hours including nighttime and during the Christmas break. The production hours are tabulated on the following page. 


\begin{tabular}{|c|c|c|c|c|}
\hline Building & Production time & $\begin{array}{l}\text { Days/ } \\
\text { week }\end{array}$ & $\begin{array}{l}\text { Time the lights could } \\
\text { potentially be tumed off }\end{array}$ & $\begin{array}{c}\text { Total } \\
\text { nrweek }\end{array}$ \\
\hline $\begin{array}{c}\text { Press Shop, Steel } \\
\text { Store and Heavy } \\
\text { Tool Room }\end{array}$ & $\begin{array}{c}6: 00-14: 30+14: 00-22: 30+ \\
\text { weekend preparation }(6: 00 \\
-14: 00)\end{array}$ & $5+2$ & $\begin{array}{c}23: 00-5: 00 \text { (during the } \\
\text { week)+15:00-5:00 (during } \\
\text { the weekend) }\end{array}$ & $30+28=58$ \\
\hline Body Shop & $\begin{array}{c}6: 00-14: 30+14: 00-22: 30+ \\
\text { weekend }(6: 00-14: 00)\end{array}$ & $5+2$ & $\begin{array}{c}23: 00-5: 00 \text { (during the } \\
\text { week)+15:00-5:00 (during } \\
\text { the weekend) }\end{array}$ & $30+28=58$ \\
\hline Assembly Hall & $6: 00-14: 30+14: 00-22: 30$ & 5 & $\begin{array}{c}23: 00-5: 00 \text { (during the } \\
\text { week)+0:00-24:00 (during } \\
\text { the weekend) }\end{array}$ & $30+48=78$ \\
\hline $\begin{array}{l}\text { Pressed Part } \\
\text { Warehouse }\end{array}$ & $6: 00-14: 30+14: 00-22: 30$ & 5 & $\begin{array}{c}23: 00-5: 00 \text { (during the } \\
\text { week) }+0: 00-24: 00 \text { (during } \\
\text { the weekend) }\end{array}$ & $30+48=78$ \\
\hline Machining Hall & $6: 00-14: 30+14: 00-22: 30$ & 5 & $\begin{array}{c}23: 00-5: 00 \text { (during the } \\
\text { week)+0:00-24:00 (during } \\
\text { the weekend) }\end{array}$ & $30+48=78$ \\
\hline $\begin{array}{l}\text { Container and } \\
\text { Receiving } \\
\text { Warehouse }\end{array}$ & 3 shifts (24hrs/day) & 5 & 8 & 0 \\
\hline
\end{tabular}

Table 13 - Production hours by area

Thus the total time the lights can be turned off adds up to the following:

\begin{tabular}{|c|c|c|c|c|c|}
\hline Building & $\begin{array}{l}\text { Weeks of } \\
\text { production }\end{array}$ & $\begin{array}{l}\text { Hour lights } \\
\text { can be } \\
\text { turned off }\end{array}$ & $\begin{array}{c}\text { Weeks without } \\
\text { production }\end{array}$ & $\begin{array}{c}\text { Hours lights } \\
\text { can be } \\
\text { turned off }\end{array}$ & $\begin{array}{l}\text { Total hours } \\
\text { lights can } \\
\text { be turned } \\
\text { off hrlyr }\end{array}$ \\
\hline $\begin{array}{l}\text { Press Shop, } \\
\text { Steel Store } \\
\text { and Heavy } \\
\text { Tool Room }\end{array}$ & 53 & 58 & 3 & 24 & 3146 \\
\hline Body Shop & 53 & 58 & 3 & 24 & 3146 \\
\hline Assembly Hall & 53 & 78 & 3 & 24 & 4206 \\
\hline $\begin{array}{l}\text { Pressed Part } \\
\text { Warehouse }\end{array}$ & 53 & 78 & 3 & 24 & 4206 \\
\hline Machining Hall & 53 & 78 & 3 & 24 & 4206 \\
\hline $\begin{array}{l}\text { Container and } \\
\text { Receiving } \\
\text { Warehouse }\end{array}$ & 53 & 0 & 3 & 24 & 72 \\
\hline
\end{tabular}

Table 14 - Total time that lights can be turned off by area 


\section{Anticipated Savings:}

The estimated energy conservation, $E C$, for replacing lamps in a specific area is given by the following relation:

$$
E C=\frac{N \times C F W \times H}{C_{1}}
$$

where,

$$
\begin{aligned}
N & =\text { number of fixtures in area, no units } \\
\text { CFW } & =\text { power rating of current fixtures in area, } \mathrm{W} \\
H & =\text { non operating hours of lamp in area, } \mathrm{h} / \mathrm{yr} \\
\mathrm{C}_{1} & =\text { conversion constant, } 1,000 \mathrm{~W} / \mathrm{kW}
\end{aligned}
$$

The demand reduction, $D R$, associated in a specific area is given by the following relation:

$$
D R=\frac{N \times C F W \times C F}{C_{1}}
$$

where,

$$
\begin{aligned}
C F= & \text { coincidence factor }- \text { probability that the equipment contributes } \\
& \text { to the facility peak demand, per month }
\end{aligned}
$$

Therefore, the total annual cost savings, TCS, can be estimated as follows:

$T C S=(E C \times$ energy rate $)+\left(D R \times\right.$ demand rate $\left.\left.^{1}\right) \times 12 \mathrm{mo} / \mathrm{yr}\right)$

Total annual cost savings for each area are shown in the table below: 


\begin{tabular}{|c|c|c|c|c|c|c|c|}
\hline Building Area & $\begin{array}{c}\text { Existing } \\
\text { Ballast/Lamp } \\
\text { Description }\end{array}$ & $\begin{array}{c}\text { Number } \\
\text { of } \\
\text { Fixtures }\end{array}$ & $\begin{array}{c}\text { Fixture } \\
\text { Power } \\
W\end{array}$ & $\begin{array}{c}\text { Total } \\
\text { Power } \\
W\end{array}$ & $\begin{array}{l}\text { Usage } \\
\text { Time } \\
\text { hlyr }\end{array}$ & $\begin{array}{c}\text { EC (Total } \\
\text { Energy } \\
\text { Saving) } \\
\text { kWh/yr }\end{array}$ & $\begin{array}{c}\text { TCS (Total } \\
\text { Annual Cost } \\
\text { Savings) } \\
\text { Ryr } \\
\end{array}$ \\
\hline Machining Hall & 400W MV & 260 & 454 & 118040 & 4206 & 496476 & 89256 \\
\hline $\begin{array}{l}\text { Machining Hall } \\
\text { Container }\end{array}$ & 400W HPS & 5 & 457 & 2285 & 4206 & 9610 & 1727 \\
\hline $\begin{array}{l}\text { Warehouse } \\
\text { Container } \\
\text { Warehouse }\end{array}$ & $\begin{array}{l}\text { 400W MV } \\
\text { 400W HPS }\end{array}$ & 134 & 454 & 60836 & 72 & 4380 & 349 \\
\hline $\begin{array}{l}\text { Press Shop } \\
\text { Steel and Heaw }\end{array}$ & $400 \mathrm{~W} \mathrm{MV}$ & 231 & 454 & 104874 & 3146 & 329933 & 59315 \\
\hline $\begin{array}{l}\text { Tool Store } \\
\text { Pressed Part }\end{array}$ & 400W MV & 120 & 454 & 54480 & 3146 & 171394 & 30813 \\
\hline $\begin{array}{l}\text { Warehouse } \\
\text { Pressed Part }\end{array}$ & $400 \mathrm{WMV}$ & 184 & 454 & 83536 & 4206 & 351352 & 66 \\
\hline Warehouse & 400W HPS & 28 & 457 & 12796 & 4206 & 53819 & 75 \\
\hline Body Shop & $400 \mathrm{~W}$ MV & 190 & 454 & 86260 & 3146 & 271374 & 48787 \\
\hline Body Shop & 400W HPS & 11 & 457 & 5027 & 3146 & 15814 & 2843 \\
\hline Assembly Hall & 400W MV & 479 & 454 & 217466 & 4206 & 914662 & $16443 \pi$ \\
\hline Assembly Hall & 400W HPS & 27 & 457 & 12339 & 4206 & 51897 & 9330 \\
\hline TOTALS & & 1728 & & 784902 & & 2672657 & 480490 \\
\hline
\end{tabular}

Table 15 - Total annual cost savings by area

Avoided Electric Cost: R $0,17978 / \mathrm{kWh}$ (values in this table include VAT)

From the table above it can be seen that turning the bay lights off in each area during non-production time will result in an electrical energy saving of 2 $672657 \mathrm{kWh}$ / year and a total cost saving of R 480490 / year (including VAT). Maximum demand occurs during production time and will not be reduced by this action.

\section{Anticipated Costs:}

The easiest way this saving can be implemented is by somebody going around the whole plant and turn the lights off. Considering a labour cost of $\mathrm{R} 50 /$ hour and a time consumption of 30 minutes to turn the lights off, the costs add up to the following: 


\begin{tabular}{|c|c|c|c|}
\hline Building & $\begin{array}{c}\text { Production: } \\
\text { days/ week }\end{array}$ & $\begin{array}{c}\text { Production: } \\
\text { weeks/year }^{(1)}\end{array}$ & $\begin{array}{c}\text { Total } \\
\text { Days }\end{array}$ \\
\hline $\begin{array}{c}\text { Press Shop, Steel } \\
\text { Store and Heavy Tool } \\
\text { Room }\end{array}$ & $5+2$ & 49 & $7 \times 49=343$ \\
$\begin{array}{c}\text { Body Shop } \\
\text { Assembly Hall }\end{array}$ & $5+2$ & 49 & $7 \times 49=343$ \\
$\begin{array}{c}\text { Pressed Part } \\
\text { Warehouse }\end{array}$ & 5 & 49 & $5 \times 49=245$ \\
$\begin{array}{c}\text { Machining Hall } \\
\text { Container and }\end{array}$ & 5 & 49 & $5 \times 49=245$ \\
Receiving Warehouse & 5 & 49 & $5 \times 49=245$ \\
\hline
\end{tabular}

Table 16 - Production days/year by area

Using the maximum of 343 days where lights are to be turned on and off, costs add up to:

343 days / year $\times R 100 /$ day $=R 34300$ / year

Hence the Total Annual Savings are:

$R 480490 /$ year $-R 34300 /$ year $=R 446190 /$ year

(1) 52 weeks / year minus 3 weeks of vacation 
ECO 9a - Install direct acting electric heaters to air replacement plants serving colour line 1

Estimated Electric Demand Increase:

8925 kVA

Estimated Total Cost Savings:

R 4 355536/yr

Estimated Implementation Cost:

R 4000000

Simple Payback:

$<1$ year

\section{Recommended Action}

Investigate the practicality of installing direct acting electric heater elements ahead of the gas burners, together with the necessary temperature controls and maximum demand control.

\section{Background}

The paint tunnel receives heated and humidified air from five Air

Replacement Plants (ARPs). The total supply air volume is about $200 \mathrm{~m}^{3} / \mathrm{s}$ and all of it is exhausted to atmosphere. The supply air is heated by direct gas burners in the ARPs and humidified by water sprays. The exhaust air passes through a water bath before being discharged to atmosphere.

Eskom (Industrelek) have produced a report (for VW SA) showing that direct acting electric heating is cheaper to use than the presently installed Liquid Petroleurn Gas (LPG) heating. We have verified their calculations and can agree with the basic figures leading up to total energy consumption and corresponding cost of gas fuel.

The average enthalpy for the year is $33,14 \mathrm{~kJ} / \mathrm{kg}$ of dry air with the enthalpy of the air at the design condition around $58 \mathrm{~kJ} / \mathrm{kg}$ of dry air [CSIR Research Report 300]. The specific mass of the air at this condition is approximately $0,825 \mathrm{~m}^{3} / \mathrm{kg}$. 
The energy consumption for an eleven-month year at 557 hours per month is then given by:

$$
(200 / 0,825)^{*}(58-33.14) * 557 * 11=36925387 \mathrm{kWh}
$$

This is close to the Industrelek figure of $34881485 \mathrm{kWh}$ for a relatively warm year. (Note that the supply air condition rather than the design air condition should be used in both calculations. However, the difference is not significant in the context of imprecise knowledge of operating hours)

In addition, their claim that electric heating at about $70 \%$ of the design (worst case) load will cover about $80 \%$ of the energy requirements is what one would normally expect.

Anticipated savings

Please see the Industrelek report for full details.

Note! These calculations are extremely sensitive to average annual weather loads and, more particularly, hours of operation. It can be seen from the invoices that the total annual bill for LPG during the year of investigation was only R8 393800 , about $25 \%$ lower than the calculated value. 
ECO 9b - Extend existing thermic oil/HFO system to supply the ARP (HFO instead of gas)

Estimated energy cost saving:

Estimated installation cost:

Estimated payback:
R 4656666

R 19000000

4,1 years

\section{Recommended action}

Install an additional HFO heater to supply heated thermic oil to the ARP (to replace the gas fired system completely)

\section{Background}

The costs of the various fuel options on site are

Gas: $\quad \mathrm{RO}, 32 / \mathrm{kWh}$ at $100 \%$ efficiency

HFO: $\quad R 0,14 / k W h$ at $100 \%$ efficiency

Electricity: $\quad \mathrm{R} 0,15771 / \mathrm{kWh}$ (or $\mathrm{R} 0,21 / \mathrm{kWh}$ average including present demand charges)

The cost of HFO makes it attractive when compared with gas and electricity and an additional thermic oil heater should be considered to replace the gas-fired system completely. The heat recovery option (ECO 11) would still be valid.

\section{Anticipated Savings}

The cost of useful heat from the HFO/thermic oil system is about $\mathrm{R} 0,187 / \mathrm{kWh}$, assuming an overall system efficiency of $75 \%$. The cost of the $34881485 \mathrm{kWh}$ ARP energy consumption then becomes R6 511210 (at 75\% system efficiency), which represents a saving of R4 656666 per year against the R11 167877 gas bill.

\section{Implementation Cost}

The estimated cost of an extension to the HFO/thermic oil system is about $R 19000000$, which gives a payback period of 4,1 years. (Cost estimate acquired from Mr Jorg Steinbach, Oilco Engineering, Port Elizabeth who 
did the original HFO heater installation at the plant. They are also agents for Konus Kessel and have recently priced a similar conversion)

Note! These calculations are extremely sensitive to average annual weather loads and, more particularly, hours of operation. It can be seen from the invoices that the total annual bill for $L P G$ during the year of investigation was only R8 393800 , about $25 \%$ lower than the calculated value. 
ECO 10 - Make use of heat pump heat recovery between ARP exhaust and supply air streams

Estimated energy saving:

Estimated energy cost saving:

Estimated installation cost:

Estimated payback:
1313843 litres of gas

R 3187385

$R 2750000$

0,87 years

\section{Recommended Action}

Install a heat pump heat-recovery unit between the ARP exhaust and supply air streams.

\section{Background}

Air leaves the water baths below the paint tunnels at $23^{\circ} \mathrm{C}$ and $70 \% \mathrm{RH} . \mathrm{A}$ good deal of energy can be extracted from this air by cooling it to about $10^{\circ} \mathrm{C}$ and $90 \% \mathrm{RH}$. The actual potential rate of heat extraction is given by

$$
200 \mathrm{~m}^{3} / \mathrm{s} \times 1 / 0,83 \mathrm{~m}^{3} / \mathrm{kg} \times(54-27) \mathrm{kJ} / \mathrm{kg}=6400 \mathrm{~kW} \text { approximately }
$$

Typically this would result in a heat pump heat output of $8000 \mathrm{~kW}$, based on a cooling coefficient of performance of 4 . That is, the compressor input power would be about $1600 \mathrm{~kW}$.

It is clear from the (Idustrelek) profile of monthly energy consumption that a machine delivering about $1000 \mathrm{MWh}$ heating per month would run throughout the year. This is because the month of smallest need is February at about 963 MWh. Bigger capacity and or additional machines would be increasingly less cost effective since the number of over-capacity hours increases as a proportion of the available hours. 


\section{Anticipated Savings}

Using the nominal monthly run figure of 557 hours gives a machine requirement of about $1700 \mathrm{~kW}$ heat output. Typically, such a machine would have a compressor input of about $360 \mathrm{~kW}$, effectively reducing the cost of heating to about $\mathrm{R} 0,04 / \mathrm{kWh}$ (including the increase in demand charges).

The cost of providing recovered heat all year round would then be $1700 \mathrm{~kW} \times 557$ hours/month $\times 12$ months $\times 0,04 \mathrm{R} / \mathrm{kWh}=\mathrm{R} 454512$

The remaining energy (gas) cost would be $(34881485-(1700 \times 557 \times 12)) \mathrm{kWh} \times \mathrm{R} 0,32 / \mathrm{kWh}=\mathrm{R} 7525979$ where $34881485 \mathrm{kWh}$ is the total annual energy consumed in a design year at a cost of $R 11167877$ and $R 0,32 / \mathrm{kWh}$ is the cost of gas.

The annual fuel cost has been reduced to $R 7980491$, which results in a cost saving of $R 3187385$ (1 313843 litres of gas)

The installed cost of the heat pump heat recovery system is estimated at R 2750000 , based on an industry guideline of about R 2000 per $\mathrm{kW}$ of cooling capacity: $(1700-360) \mathrm{kW} \times \mathrm{R} 2000 / \mathrm{kW}=\mathrm{R} 2680000$, rounded up to cover possible contingencies. This results in a payback period of 0,87 years (about 10 months).

Note: Mr Des Smith at Improvair, East London provided advice for estimates of cost and capacity of heat pumps. He knew of the plant situation and has done related work for Daimler-Chrysler. 


\subsubsection{Additional items considered}

AIC 1 - Identify and switch off equipment that is not essential during non-production time.

\section{Recommended action}

Identify and visibly mark or signpost equipment that should be running during non-production time. Switch off all other equipment at the end of the production period.

\section{Background}

Electrical power demand during zero-production time is more than a third of the power demand during peak production time. It is likely that electrical energy wastage is occurring because of electrical equipment left running unnecessarily. There is a need to identify the essential equipment (which is presumably less than the non-essential equipment) and take steps to ensure that only that equipment is left running during non-production time.

Recorded graphs of kVA in July 2001 show the electrical demand for Plant A peaking at about 17 MVA. During zero-production time the 20 hour period from Saturday 10:00 to Sunday 6:00) the total electrical demand was measured at 6 MVA (6 000kVA). Electrical demand is recorded at three of the four substations (Sub 12, Sub 17A and Sub 17B) that are fed directly from the Main Substation. Assuming that the fourth substation (13B) accounts for the remaining demand, then the demand is split in the following ways. 


\begin{tabular}{|c|c|c|c|}
\hline & & Sub & Area \\
\hline & & 12 & engine shop \\
\hline & Rino main & 15 & offices \\
\hline & through: & 22 & computer room and offices \\
\hline & Sub 12 & 1 & $\begin{array}{l}\text { Intermediate store, sub-assembly, } \\
\text { offices and workshops }\end{array}$ \\
\hline & (1600 kVA) & 9 & offices and warehouse \\
\hline & [measured] & 4 & press shop and body shop \\
\hline & & 3 & body shop \\
\hline & and Sub 13B & 26 & body shop (roof) \\
\hline & (1 $200 \mathrm{kVA})$ & 25 & body shop (roof) \\
\hline & [remainder] & 24 & body shop (roof) \\
\hline & & 14 & press shop \\
\hline & Total & 10 & press shop, general and body shop \\
\hline Main incoming & & 16 & quality asurance offices \\
\hline Sult & & 11 & warehousing (CKD) \\
\hline & & $13 \mathrm{~B}$ & - \\
\hline$(6000 \mathrm{kVA})$ & & 27 & Engine Shop \\
\hline [measured] & Supply through & 18 & $\begin{array}{l}\text { Paint Shop, General and Electro- } \\
\text { coating Plant }\end{array}$ \\
\hline & Sub 17A & 28 & First Colour Line - Paint Shop \\
\hline & & 19 & Prime Paint Line - Paint Shop \\
\hline & $(1600 \mathrm{kVA})$ & 23 & First Colour Line - Paint Shop \\
\hline & [measured] & 20 & $\begin{array}{l}\text { Paint Shop, General and Electro- } \\
\text { coating Plant }\end{array}$ \\
\hline & & 21 & Boiler House - Electro-coating Plant \\
\hline & & 8 & EC Plant, Power Rails - Paint Shop \\
\hline & Supply through & $13 \mathrm{~A}$ & 350 kVA to Assembly Hall \\
\hline & Sub 17B & 7 & Paint Shop General \\
\hline & & 6 & Third Colour Line \&General Paint Shop \\
\hline & $(1600 \mathrm{kVA})$ & 5 & Offices \& Paint Shop \\
\hline & [measured] & 2 & $\begin{array}{l}\text { Compressor House, Pilot Hall, } \\
\text { Ablutions \& Fire Station }\end{array}$ \\
\hline
\end{tabular}

Table 17 - Electrical demand during zero-production time

Table 17 is the first step in identifying where the energy is going during zero-production. The next step will be to monitor the individual substations during the zero-production period. Once the essential processes have been identified, the proportion of the $6000 \mathrm{kVA}$ that is justifiable will be known and can be targeted.

Anticipated Savings

Savings can only be known once further investigation has been completed. An indicator of the extent of possible savings is the cost of the 
current $6000 \mathrm{kVA}$ load. Over a year of weekly 20 hour periods, $6000 \mathrm{~kW}$ (ignoring power factor) will cost:

$6000 \mathrm{~kW} \times 20 \mathrm{hr} /$ week $\times 49$ weeks/year $\times \mathrm{R} 0,17978 / \mathrm{kWh}=\mathrm{R} 1057106 /$ year

If demand can be reduced by just a quarter during this 20 hour period ( $1500 \mathrm{kVA}$ - a couple of air conditioners and chiller units) a saving of about R 250000 /year will be achieved.

AIC 2 - Spread electrical demand to reduce peak kVA costs Recommended Action

Turn off non-essential electrical equipment at times that correspond to peaks of maximum electrical demand. Run processes that could be operated at off-peak times only, only at off-peak times.

\section{Background}

Savings through spreading electrical demand will not be easy to achieve. The maximum demand curve (see over the page) is relatively flat each side of lunchtime. There is a fairly regular morning undulation from peak to trough of between 500 and $1000 \mathrm{kVA}$, peaking at about 08:30 and 11:30. If this undulation were perfectly flattened out, peak reduction of 250 to 500 kVA would be achieved representing a saving of R8 000 to R16 000 per month (@R32,38/kVA).

Turning off equipment like air-conditioners is not feasible because the maximum load occurs over an extended period during the day. The most headway will be made by identifying which processes can be run at offpeak times. 
AlC 3 - Make use of water from effluent plant to reduce water consumption and effluent costs.

\section{Recommended Action}

If economically beneficial, install equipment and pipe work to further treat effluent so that it can be re-used in place of freshwater for certain processes in the plant.

\section{Anticipated savings}

To determine the economic effectiveness of this action, the quantity of water that could be re-used will need to be established. For each kilolitre of fresh water saved, the cost of effluent corresponding to that kilolitre of fresh water will also be saved.

On the negative side would be the cost of treatment per kilolitre.

Engineering personnel have indicated that an investigation into effluent treatment and re-use has already been performed, and a detailed report has been produced but was not available during the time of the assessment. 
AlC 4 - Install Skylights and photosensor light controls

Estimated Electric Energy Savings: $\quad 804776 \mathrm{kWh} / \mathrm{yr}$

Estimated Electric Energy Cost Savings: R 303 314/yr

Estimated Total Cost Savings: $\quad$ R $303314 / \mathrm{yr}$

Estimated Implementation Cost: $\quad$ R 2844900

Simple Payback $=9$ years

\section{Recommended Action}

Install skylights and use photo sensors to control artificial (electrical) lighting. Photo sensor devices allow control of lighting during periods when natural sunlight from exterior windows and skylights is adequate. Savings are due to reduced operating hours from the photosensor controlled light fixtures.

\section{Background}

The reasoning behind this ECO was that clean skylights transmit enough sunlight in a building for ambient light purposes during a clear day hence the bay lights could be turned off. Energy savings would accrue from reduced electrical costs. Dirty/old skylights need to be replaced.

\section{Skylights}

The use of skylights will result in energy savings by reducing the number of lights that have to be turned on during the day. The table below shows how clean polycarbonate skylights transmit sunlight as opposed to dirty fiberglass skylights. All values are measured at ground level during a partly cloudy day.

\begin{tabular}{|c|c|c|c|}
\hline \multicolumn{2}{|c|}{ Assembly Hall } & \multicolumn{2}{c|}{ Container Warehouse } \\
\hline Clean Skylights & Dirty Skylights & Clean Skylights & Dirty Skylights \\
\hline 751 lux & 98 lux & 595 lux & 158 lux \\
\hline
\end{tabular}

The methodology of the measured values is as follows: In the Assembly Hall and the Container Warehouse, two measurements of luminous intensity 
were taken below clean and dirty skylights in turn. The first measurement was taken during the day with lights on and the second measurement was taken during the night with the lights on. The difference between the two measurements (the contribution from the skylights) is shown in the table above. The impact of skylight cleanliness is clearly shown.

The lowest measured clean skylight value is 595 lux and highest measured dirty skylight value is 158 lux. The difference of those values, 437 lux, gives an idea of how much the lighting level in the plant increases if all dity skylights are replaced with clean skylights. It moreover indicates that if the bay lights are turned off it is easily compensated by the increase of lux from clean polycarbonate skylights.

\section{Photosensor (Photocell) Controls}

Photocells are light-sensitive switches that are available in various sensitivities. During daylight hours the lamp is off and it turns on when the light level drops below the light level set-point of the control. It is best to use controls that are designed to turn the light on when the control fails; this is particularly important for security lights.

The installation of skylights will allow natural light to illuminate the plant during days without heavy fog or thunderstorms. A mixture of 400 watt high pressure sodium and 400 watt mercury vapor lamps provides the existing lighting in the area. The area of the pertaining rooms was estimated to be $59000 \mathrm{~m}^{2}$. The ceiling height is approximately eight to eleven metres (except for the steel store and the press shop with an approximate ceiling height of 17 metres). It was assumed for the calculations that the skylights could provide sufficient lighting 7,8 hours per day each of days the area is used. The number of days when the skylights would not provide sufficient light due to thunderstorms or heavy fog was also be taken into account when calculating the hours per year the lights will be left off. 


\section{Area of investigation}

The comparison of present lighting levels during daytimes with the condition of skylights makes it possible to get a clear impression where the replacement of the skylights and at the same time tuming off bay lights is feasible. In the Machining Hall, the Press Shop, the Steel Store and the Container Warehouse sufficient correlations are found. Those parts of the plant are the focus of the calculations involved in this ECO. However, the Assembly Hall, the Body Shop and the Pressed Part Warehouse appeared to be a more complex issue. In the Assembly Hall conveyor belts and production lines obscure the light transmitted through the skylights especially in the middle of the building. Inside the Body Shop highly positioned conveyor belt and production lines as well as high rooms also decrease the amount of light from the skylights. Furthermore the skylights in the Body Shop are mainly glass skylights which transmit sunlight much better than polycarbonate and are easier to clean. Therefore the skylights in the Body Shop are not considered as a possible replacement. In the Pressed Part Warehouse highly stockpiled boxes obscure the lighting level, too. Thus further investigation for the ideal solution is necessary in those parts of the plant.

Number of skylights needed:

The number of skylights needed depends on the condition of the skylights. Fiberglass deteriorates with age, exposing fibres that collect dust and render them almost opaque. Some of the fibreglass skylights have been replaced by polycarbonate, a smooth (therefore does not attract dust), long-lasting polymer. From an inspection of the plant, the skylights have been subdivided into clean (mostly polycarbonate), fairly clean (mostly fiberglass) and dirty (all fiberglass) as indicated in the Figures below. Cleaning of the skylights is a temporary option to increase the amount of light penetrating the skylight but this is labour intensive and would require ongoing attention. However, because of the long lasting (about 10 to 15 years) clean condition of the 
polycarbonate the cleaning cost is not included in the cost calculations. In calculations in this section, fairly clean skylights (generally old fiberglass) have been grouped with dirty (fiberglass) skylights because they need to be replaced by polycarbonate. Drawings showing the condition of skylights are presented in APPENDIX F

\section{Anticipated savings}

The cost savings are due to switching off lights during daytime when sufficient light is transmitted through the skylights. The estimated energy conservation, $E C$, for replacing lamps in a specific area is given by the following relation:

$$
E C=\frac{N \times C F W \times H}{C_{1}}
$$

$N=$ number of fixtures in area that could be turned off, no units

CFW = power rating of current fixtures in area, $W$

$H=$ non operating hours of lamp in area, $h / y r$

$\mathrm{C}_{1}=$ conversion constant, $1000 \mathrm{~W} / \mathrm{kW}$

The demand reduction, $D R$, associated in a specific area is given by the following relation:

$$
D R=\frac{N \times C F W \times C F}{C_{1}}
$$

$C F=$ coincidence factor - probability that the equipment contributes to the facility peak demand, per month

Therefore, the total annual cost savings, TCS, can be estimated as follows:

$$
\text { TCS }=(E C \times \text { energy rate })+\left(D R \times \text { demand rate }{ }^{1)} \times 12 \mathrm{mo} / \mathrm{yr}\right)
$$

The following table is a summary of the anticipated savings from switching off lights during the day, and shows the anticipated savings per year for each area of the plant. 


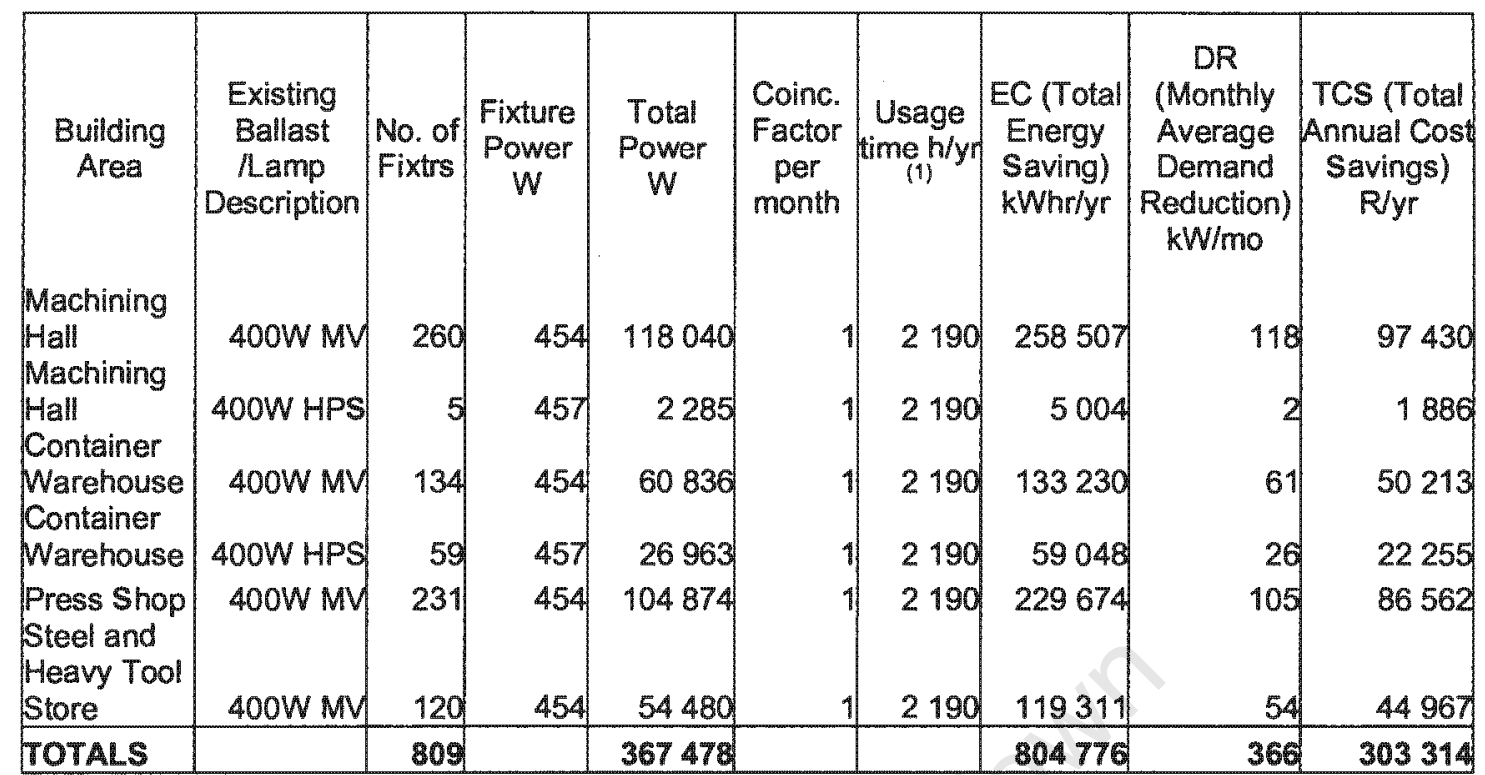

Average Power Factor October 1999 - July 2000 assumed to be 0,9

Avoided Electric Cost: R 0,17978 / kWh

Avoided Demand Cost: $R 35,973 / \mathrm{kW}$

(1) South African Weather Service: Thunderstorms 14 days per year, Fog 24 days per year, Average of 7,8 hours of sunshine per day

Table 18 - Anticipated savings from switching off bay lights during the day

\section{Total Costs of Skylights}

Estimates for replacement of the dirty skylights were obtained from two independent roofing contractors.

\section{Estimate 1:}

One $24 \mathrm{~m}$ section was quoted to cost $\mathrm{R} 20000$. A total of 61 sections are required for the machining hall, see APENDIX $F$, hence the total price is $R$ 1220000 .

\section{Estimate 2:}

The cost for the whole recommended replacements was estimated at R 2832900 . 


\section{Cost of photo sensors:}

Costs are shown in the table below.

\begin{tabular}{|l|c|c|c|}
\hline \multicolumn{1}{|c|}{ Building Area } & $\begin{array}{c}\text { Number } \\
\text { of Photo } \\
\text { sensors } \\
\text { needed }\end{array}$ & $\begin{array}{c}\text { Total } \\
\text { installation } \\
\text { Cost }^{(1)}\end{array}$ & $\begin{array}{c}\text { Total } \\
\text { implementation } \\
\text { Costs }\end{array}$ \\
\hline Machining Hall & 4 & R1 000 & R4 000 \\
Container Warehouse & 4 & R1 000 & R4 000 \\
Press Shop & 4 & R1 000 & R4 000 \\
Steel and Heavy Tool Store & 4 & R1000 & R4000 \\
\hline TOTALS & 16 & & R16000 \\
\hline
\end{tabular}

Table 19 - Cost of photo sensors

Payback period:

The calculation of payback period is shown below.

\begin{tabular}{|l|c|c|c|c|}
\cline { 2 - 5 } \multicolumn{1}{c|}{} & $\begin{array}{c}\text { Total annual } \\
\text { cost saving } \\
(\mathrm{R} / \mathrm{yr})\end{array}$ & $\begin{array}{c}\text { Total cost of } \\
\text { skylights }(\mathrm{R})\end{array}$ & $\begin{array}{c}\text { Total cost of } \\
(\mathrm{R})\end{array}$ & $\begin{array}{c}\text { Pay back } \\
\text { period }(\mathrm{yr})\end{array}$ \\
\hline $\begin{array}{l}\text { Estimation 1 } \\
\text { (Only Machining hall) }\end{array}$ & 97430 & 1220000 & 4000 & 13 \\
\hline $\begin{array}{l}\text { Estimation 2 } \\
\text { (Total replacements considered) }\end{array}$ & 303314 & 2832900 & 12000 & 9 \\
\hline
\end{tabular}

Table 20 - Calculation of payback period

The payback period of at least 9 years is very high. Moreover, after this period, the maintenance of the skylights also has to be considered. Based on the two quotes obtained (which varied significantly), retums from energy cost savings through skylights and photo sensors do not justify implementation. It is recommended that more quotes for skylight replacement be obtained - which may prove to be low enough to make this action economically viable.

\footnotetext{
(1) Number of circuits is unknown. Nominal allowance is estimated to be four sensors per hall under the assumption that it will be practical to install the sensors. The installation cost includes sensors, wiring, labour, and conduit (Rewiring may be needed).
} 


\subsubsection{Outcomes of the assessment presentation to}

management

Top management (directors) did not attend the presentation. The Engineering Manager had arranged that managers from the Finance, Human Resources and Procurement departments were present, along with several engineers from his Engineering department. Before the meeting began, the Engineering Manager informed the group that compressed air consumption had already been reduced by $40 \%$.

The following staff ratios were recorded:

- Total managers $= \pm 120$

- Manager/staff level (1/200)

- Supervisor/staff level (1/35)

The following points on the importance of energy efficiency were made:

- The Plant Finance Manager confirmed that expenditure on energy is roughly $5 \%$ of total overheads (excluding manpower) and represents approximately $10 \%$ of controllable costs. Agreed potential energy cost savings (as shown in the assessment report) are in the region of $R 11$ 000000 per annum.

- If energy is included as a key performance indicator for personnel evaluation (Section Managers) then energy consumption for each section would need to be monitored.

The following issues arose when the suggestion was made to create separate departmental energy budgets:

- This would be a sound policy if and only if monitoring of each department is achieved. Measurement and records of energy used by each department would be required.

- There was concern that agreement over energy budget allocations might not be achievable. 
- There was a concern that the administrative burden might impact negatively on the flexibility of the plant.

- The cost estimate for all necessary monitoring equipment is approximately R300 000 (estimate from the 'Monitoring and Verification' document produced by D Van Es and Siboniso Khumalo, ERI, UCT)

- It was pointed out that different products would use different amounts of energy and that energy reticulation systems (electrical circuits, compressed air ...) overlap geographical section boundaries

- A suggestion was made to include a particular utility (compressed air, electricity ...) within a particular manager's area of responsibility (create a 'compressed air manager' and an 'electricity manager'). It was put forward that this would generate a higher level of awareness of the different utilities.

The last point led on to the concept of appointing an Energy Manager. The Engineering Manager currently dealt with energy issues within his portfolio. Discussion produced the following responses:

- The energy manager may become the scapegoat for all energy issues and possibly would not promote the culture that energy is everyone's responsibility.

- The Engineering Manager emphasised that the job description would need to include time and resources for investigating ideas for energy saving - not just for ensuring energy delivery.

- The point was made that $\mathrm{VW}$ is an international company with the goal of reducing headcount to a set target headcount. The Human Resources department would need to determine whether an energy manager could be appointed within the target headcount.

Two issues were identified as crucial to successful energy management. 
- Firstly, the culture of irresponsibility towards energy use needs to be changed, but this is difficult to quantify.

- Secondly, energy-saving projects need to be prioritised and then require action.

When the obstacles to successful energy management were considered, all were related to financial systems and budgets. The following points arose.

- A budget for project investigation (a salary) would be required for successful energy management.

- Current budgets limit capital expenditure (CAPEX) and expenditure on overheads.

- Current budgets are based on expected return on investment (ROI) for the following year.

- CAPEX approval is focussed on car sales predictions - not energy cost savings. (Producing more cars is seen to be more worthwhile than saving costs.)

- Highest priority projects are those that will ensure uninterrupted production (Again, protection of the top line).

- Funding for energy related projects would currently come out of the planning budget. The planning budget is approximately $45 \%$ of the total budget.

- To create a separate budget for energy management, the General Manager of Planning (who was not present at the presentation) would need to approach the Board of Directors and motivate for an energy budget to be created (which would necessitate reductions in other budgets).

The following responses relate to the question of what suitable forum could be used for conveying information about energy efficiency.

- Awareness campaigns could be run. 
- Energy efficiency could be included within the existing 'Ideas Management' system - which encourages employees to contribute ideas for technical and system improvements.

- Energy efficiency could be introduced as a feature in quarterly general staff meetings.

The possibility of including energy efficiency within the existing Quality Assurance (QA) system produced the following responses.

- The duties of the existing 'Process Quality Engineers' (PQE's) can be adjusted/changed. Current duties are based on the core functions of accountability, responsibility and knowledge.

- A concern was raised that adding additional duties to PQE's would interfere with their core functions.

Money is apparently not available for plant-wide improvement projects (such as energy efficiency projects) even if they can be shown to produce a reasonable return on investment. Comments related to this were:

- A change in mindset is needed, starting at Board level.

- Segregation of budgets shifts the focus away from corporate performance. The result is a narrow focus on departmental performance (individual budgets being carefully guarded without any vision of overall corporate performance).

- The change process needs to be elevated. Projects (such as energy efficiency projects) that have a reasonable ROI need to be presented at Board level to receive acceptance, support and funding.

- Resistance is expected from other budget holders because expenditure on plant-wide projects would reduce the size of departmental budgets.

- In order to get acceptance as a corporate project, integrity of information must be unquestionable.

- Projects that need to be dealt with on a corporate level will need to be identified. 
The financing of energy projects was discussed:

- The benefit of ESKOM's possible involvement (using demand-sidemanagement (DSM) funding) needs to be considered against selffunding.

- A link between cost savings and future CAPEX budgets does not currently exist. (The concept of a CAPEX 'reward' for energy projects, because of increased profits from energy cost savings, would not be entertained within the present system).

\section{Education and training:}

- The training centre has the capacity to present functional and leadership courses and can develop courses if there is an accepted need/demand.

- Energy would need to be part of the KPI's in order for energy training to be important or necessary.

- The decision to include energy efficiency as part of a training programme would need approval from the Board of Directors.

The following comments were made on the subject of changing the culture or attitude towards energy:

- Energy-related KPI's must be set up and cascaded downwards.

- An incentive system is already established in "Ideas Management".

- The use of an incentive system to encourage better housekeeping is not a good idea because it would be rewarding people for doing what they should be doing in the first place. People need to rather be held accountable for housekeeping.

- Awareness needs to be raised (possibly as a campaign). Previous success in environmental control was mentioned. Some possible routes for this are:

- A competition through 'Ideas Management'. 
- Raise awareness through the house newsletter and electronic notice board.

- Include energy within the quarterly union feedback meeting.

- Use industrial theatre to get messages concerning energy efficiency across.

- A reward system for supervisors has recently been initiated. The aim of the system is to achieve a higher level of ownership and engagement. The reward is two tiered - being based on KPI's as well as corporate profits.

- Energy could be included in the KPI tier but performance would need to be measurable (monitoring required). Current KPI's are based on productivity, quality and throughput.

\subsubsection{Monitoring and Verification Plan}

Based on the findings of the energy assessment, a monitoring and verification document was produced by $S$ Khumalo and D Van Es of the ERI, UCT. The document covered:

- Data requirements

- Monitoring periods (pre and post-implementation of ECO's)

- Monitoring equipment

- Energy consumption baseline characterisation and adjustment

- Savings (energy, costs and emissions) calculation methodology

The report estimates the total cost of monitoring at $R 270000$, including a R10 000 allowance for commissioning and training. The estimated total cost of all the energy cost saving measures is R12 825098 which makes the $M \& V$ approximately $2 \%$ of this value. In addition, an Energy Manager would cost the company a further R150 000 per year. 
The M\&V report presented the following recommendations:

- Appoint a Project Manager with the sole responsibility of setting up and delivering all the requirements up to and including post-intervention monitoring and data collection

- Make a preliminary inspection of the plant under consideration, taking spot measurements and performing rough calculations to identify the most likely (feasible) opportunities for energy conservation.

- Note that non-electrical loads do not present an opportunity for Demand Side Management and that fuel substitution, while reducing energy costs, may not reduce the energy requirement to a process.

- Decide which energy (cost) saving opportunities are worth pursuing and consider how the existing (pre-intervention) and post-intervention energy consumption and costs can be simply, yet, reliably, assessed and monitored.

Note! Do not implement energy conservation measures before the existing energy consumption and costs have been accepted and agreed by all intended parties to the energy cost reduction programme. This is extremely important where Contract Energy Management companies may be involved.

- A (pre-intervention) baseline must be agreed between all involved parties, noting any possibilities for variations in production due to operational requirements.

- Determine and allow for the impact of changes in one variable on another, e.g., reduction in lighting power reduces the air conditioning load.

- Install measurement devices and connect to data loggers for those loads whose baseline values cannot be agreed in any other way. 
- Loads may be cyclic in nature (e.g. seasonal) and it is necessary to analyse the collected data over a period long enough to establish reasonable repeatability.

- Energy conservation measures are introduced once all involved parties reach agreement on the baseline data.

- Ensure that additional metering and data-logging equipment is introduced as may be required by implementation of the conservation measure.

- Appoint an Energy Manager whose sole function is the analysis and interpretation of the data. The Energy manager must be part of the Finance Department.

\subsubsection{Implementation}

At the time of final editing of this thesis (October 2003) there had been an encouraging turnaround in the status of energy efficiency. The German WW head office was now including requiring energy and environment as a performance indicator. A manager with the portfolio of energy and environment had been appointed. An energy management system was starting to be put in place with the formation of "work circles" and "technical teams" for dealing with energy issues. Progress was reported in the monthly plant magazine and reported to the German head office quarterly. Monitoring of $90 \%$ of electrical substations was in place. Plantwide monitoring of compressed air consumption was to be completed within two months.

ECO 1 (fixing air leaks) was beginning to be addressed. An air-leak tagging system was in place and the plant had reduced its compressed air consumption by $16 \%$. ECO 3 (switching off compressors) had been implemented. ECO 4 (isolating compressed air lines during nonproduction hours) was being made possible by the installation of a ringmain compressed air line. ECO 5 (install power factor correction equipment) would be completed by the end of October. ECO 6 (using 
waste heat to heat phosphate bath) was put on hold after consultants found the payback period would be too long ( 4 years as opposed to the initial 1,6 years predicted by this assessment). ECO 7 (install high efficiency lighting) was being addressed. Sixteen automatic voltage reduction devices had been installed on all major lighting circuits and 4000 lamps (2,4m magnetic ballast) had been replaced with $1,5 \mathrm{~m}$ electronic ballasts). ECO 8 (turning off high bay lights) had been addressed by the installation of automatic time switches and the replacement of many of the high-bay lights with low level lighting. ECO 9 (using electricity or HFO for additional air heating in the ARP) was being investigated further, with the HFO option looking promising (after ESKOM increased electricity prices significantly). ECO 10 (heat recovery in ARP) was going to be implemented but suffered a setback when the heat pump acquisition fell through. An additional item that had received attention was the replacement of old skylights (the exact number of replacements was not available at the time of writing). 


\section{Discussion of Results}

The findings of the literature survey and the results of the case study have revealed the following:

Strong incentives exist for energy efficiency improvement in SA industry. South Africa, with its economic dependence on coal for electrical generation, produces significant quantities of GHG's - SA is the worst GHG offender in Africa. SA's GHG's are produced mainly through electricity generation from coal. In the near future, SA will be required to achieve greenhouse gas emissions targets.

SA uses roughly twice as much energy as the world average in its production. Our inefficient production is currently offset by our cheap and abundant coal. If we are forced to install cleaner coal-burning technology or reduce our coal combustion (or even pay for the externalities of coal combustion), the price of electricity will rise.

At the same time, Eskom is attempting to delay the capital cost required for more electrical peak-load generation capacity. Energy efficiency improvement, particularly in SA industry, is an effective way of achieving these three objectives.

Evidence suggests that there is much opportunity for energy cost saving through energy efficiency improvement in SA industry

The subject of the case study in this thesis is a leader in motor vehicle manufacturing in SA. Their attention to the manufacturing of an extremely high quality product did not extend to using energy efficiently.

The annual energy bill for this company was R40 000000 . Energy conservation opportunities worth R11 192000 were identified (overlapping ECO's $2 \& 4$ and optional ECO 10b not included). If the nine main ECO's were implemented, energy savings of at least R10 000000 would be 
realised (a reduction of the annual energy bill by $25 \%$ ). Seven of the nine ECO's have a payback within two years.

The results from three other energy assessments by the ERI at UCT have shown that other leaders in SA industry have also found room for improvement. Energy cost savings for South African Brewery's Prospecton plant were R1 370000 per year ( $8 \%$ of annual energy costs) with a required investment of R1 180000 and giving a payback of ten months. Energy cost savings for Anglogold's Elandsrand gold mine were R1 990000 per year with a required investment of R1 293000 and a payback of eight months. Sappi's Mandini plant was able to save R5 550000 per year in energy costs ( $5 \%$ of annual energy costs) from an investment of R3 220 000, giving an overall payback of seven months.

These case studies strongly suggest that there is significant potential for energy cost saving through efficiency improvement in SA industry.

Barriers to the implementation of energy efficiency projects exist and need to be identified, anticipated, avoided and/or addressed by policy makers and energy efficiency practitioners. The case study revealed a number of barriers to the implementation of the ECO's.

An ECO that fell within an existing budget would be implemented if the budget holder was aware of the opportunity and felt that it was part of their responsibility anyway. For example, the air leaks were fixed immediately because a budget existed that was supposed to be used for fixing air leaks. However, financing for 'improvement' projects (which is what many ECO's are) required an application for funds at a higher management level than the Engineering Manager had personal access to. Representation on this 'board' would be required. 
The Engineering Manager was the initiator of the energy assessment. The meeting after the assessment revealed that his having the answers was only the first small step towards implementing the ECO's. Also, energy in this company was being treated as an overhead. Section managers had not been held accountable for energy consumption. An energy management system was not in place (although overall energy inputs were recorded).

Most of the obstacles to implementation that were being identified in the feedback meeting were the requirements for an energy management programme. If the interest and support of top management could have been obtained early on in the project, (as is emphasised in the energy management principles in Section 2.5) the budgetary and organisational obstacles that were identified in the feedback meeting might have been easily by-passed.

A high level of trust (and creative diplomacy) is necessary between energy consultant and management in order to dispel concerns that the assessment results may show middle management to be 'at fault'.

The turnaround that occurred after the German head office became involved was exciting and encouraging and reinforced the fact that informed leadership by top management is essential for the successful implementation of energy efficiency projects in SA industry. 


\section{Conclusions}

Strong incentives exist for energy efficiency improvement in SA industry. Reduction of GHG emissions, the need to maintain economic competitiveness and the need to delay the cost of a new peak-load electrical generation plant are three objectives that can be achieved through improved energy efficiency in SA and particularly in SA industry.

Results from energy projects in industry in the USA and UK show that there is significant opportunity for energy cost saving through energy efficiency improvements. Case study assessments of industry leaders in SA suggest that SA industry is no different.

Organisation structure, financial controls and culture can be barriers to the implementation of energy projects. This can be avoided by ensuring the support of top management, and by the initiation of an energy management programme early on. The results and recommendations from the first energy assessment can then feed into an existing receptive energy management system.

Further investigation into the extent of energy management in SA industry may help in estimating the impact of energy efficiency programmes on energy consumption and energy intensity in South African industry. 
Bibliography

Bennett, K. 2001. Energy efficiency in Africa for sustainable development: A South African perspective, UNESCO Workshop on Sustainable Development, Nairobi, November 2001.

Caffall C., 1995, Learning from experiences with Energy Management in Industry, CADDET Analyses Series No. 17, CADDET, Sittard.

Cameron, J., International Carbon Markets, Electric Perspectives, March/ April 2000.

Chalmers, R. "SA needs to invest in the generation of its electricity", Business Day, 17 July 2001.

Clark, W. and Birkmire, L.K. 1999. 'Best practices in energy management: Experience with IAC assessments in the metals fabrication industry", Proceedings of the 1999 American Council for an Energy-Efficient Economy Summer Study on Energy Efficiency in Industry. ACEEE, Washington, DC

Clark, W., et al. 2000, Model report of an industrial assessment, University City Science Centre - Industrial Technology and Energy Management Division, Philadelphia.

DETR Good Practice Case Study 376, A strategic approach to energy management - The Rover Group, Department of the Environment, Transport and Regions' Energy Efficiency Best Practice Programme (DETR), Crown (UK), 1999.

Dick-Larkam, R. 1977, Cutting energy costs, Gower Press, Westmead. 
Flavin, C. 1998, Last tango in Buenos Aires, Worldwatch, pp 10-18, Nov/Dec.

Grobler, L..J., and Den Heijer, W.I.R. 2001, 'The potential needs and barriers to emission trading, joint implementation and the clean development mechanism in South Africa', Journal of Energy in South Africa, vol. 12 no. 2, pp. 377-387.

How to save energy and money, Guidebook 1 - The 3E strategy, Energy Research Institute, University of Cape Town.

How to save energy and money, Guidebook 2 - Boilers and furnaces, Energy Research Institute, University of Cape Town.

How to save energy and money, Guidebook 3 - Compressed air systems, Energy Research Institute, University of Cape Town.

How to save energy and money, Guidebook 4 - Refrigeration, Energy Research Institute, University of Cape Town.

How to save energy and money, Guidebook 5 - Steam systems, Energy Research Institute, University of Cape Town.

How to save energy and money, Guidebook 6 - Insulation, Energy Research Institute, University of Cape Town.

How to save energy and money, Guidebook 7 - Electrical use, Energy Research Institute, University of Cape Town.

Howells, M.I., and Solomon, M. 2002, 'An optimal energy and greenhouse gas mitigation path for South Africa in the short to medium term', Journal of Energy in South Africa, vol. 13 no. 4, pp. 123-129. 
Howells, M.I., and Solomon, M. 2000, 'South African greenhouse gas emissions inventory for the year 1994', Journal of Energy in South Africa, vol. 11 no. 1, pp. 273-278.

International Institute for Energy Conservation 1996. Opportunity knocks: The export market for the energy efficiency and renewable energy industry. Report for the U.S. Initiative on Joint Implementation, IIEC Publications, Washington D.C., p10.

Kirsch, F.W., Martineau, R.A., and Clark, W.J. 1996, Energy efficiency in action - A 10-year history of manufacturers' implementation and rejection of energy-conserving and cost-saving opportunities, University City Science Centre, Philadelphia.

Lennon, S.J. 1999, 'Technology transfer and its role in optimising development whilst contributing to achieving the objectives of the United Nations Framework Convention on Climate Change', Journal of Energy in South Africa, May 1999, pp. 48-51.

Mashburn, W.H. 2000, Planning for an effective energy management programme, Energy User News, www, energyusernews.com

Sorrel, S. et at. 2000 , Reducing barriers to energy efficiency in public and private organisations, [http://www.sussex.ac.uk/spru/ ] (April 2003)

Spalding-Fecher, R., Simmonds, G., and Matibe, K. 1999, 'The clean development mechanism and energy development in Africa: Climate change funding for sustainable energy', Journal of Energy in South Africa, May 1999 , pp. 34-42.

Stender, E.J, 2000, Report into a compressed air investigation, Unpublished industrial report, Edenvale. 
Winkler, H., and Mavhungu, J. 2002, 'Potential impacts of electricity industry restructuring on renewable energy and energy efficiency, Journal of Energy in South Africa, vol. 13 no. 2, pp. 43-49.

Websites

www.eia.doe.gov

www.iea.org

www.helio-international.org

www, energyusernews.com 
Appendix A - Pre-assessment data form

Primary Contact:

Phone:

Other Contact:

Phone:

Address (street and mailing):

Directions:

Principal Products: Passenger cars and light commercials

Product Distribution Area: __ Local + abroad

Annual Production (units, lbs, etc): $\pm 80000$

Annual Sales: \pm 80000 No of Employees:_ \pm 6000

In-house Energy Management Engineer;

\section{BUILDING LOCATION INFORMATION}

Number of buildings to be considered:

Refer attached document

Major Areas (i.e. processing, warehouse, office, etc.):

Area Size

Notes

Refer attached document

Building leased or owned: owned

Building Construction Date: refer attached

Wall Construction (insulation, construction materials, etc):

Refer attached

Ceilings (insulation, height, construction): 
Operating Schedules (office, production, major equipment, lights):

Production: Have hard copy available on Monday

Warehouse:

Offices:

\section{HVAC EQUIPMENT}

Heating (type, size, areas served):

Hard copy on Monday

Air Conditioning (type, size, areas served):

Controls (setbacks, EMS, etc.):

Energy Management System -

obsolete / non functional

Water Heaters (size, use, fuel): \pm 101 geysers $(2 \mathrm{kM})$ not incl. Engine plant and paintshop)

Urns - not controlled

Kettles - not controlled

\section{PROCESS EQUIPMENT}

Boilers (size, type, purpose):

Electric-2 $2 \times 36 \mathrm{~kW}$

Showers B/S \& Ass.

Thermic Oil $\times 2$

Paintshop 
Air Compressors (size, type, purpose):

$2 \times$ ingersoll Rand Centac $2 \times$ Atlas Copco ER 8 reciprocating

$3 \times$ Atlas Copco oilfree Rotary Screw Various smaller compressors throughout plant - total:2835 kW power consumption approx

Ovens/Kilns: Central ovens are heated through Parafin. Thermic Oil and LPG

Refrigeration/Process Coolers and Equipment: Cooling at Electrocoat, compressed air paintshop. lasers and colour 1 oven exit

Chillers at colour 1 prep deck, touch up deck

Painting/Plating: $1100 \mathrm{~kW}$ Air Replacement Plant at colour 1 line, 2 and 3

Other Process Equipment: _Resistance welding, laser welding, machining. phosphating and electrocoating

Rollerbeds $-0.37 \mathrm{~kW}$ each Water test area

Lighting (types, size, controls, etc.): 5 ft flurescent

$8 f t$ magnetic/elec balast

$4 f t$ flurescent

400W highbay mercury vapour

$400 \mathrm{~W}$ canopy mercury vapour

Flurescent - prep decks + touch-up decks ( $\pm 41 \mathrm{~kW}$ per deck)

\section{DATA \& SITE REQUESTS}

Yes No

$x \quad \square$ Is a conference/meeting room available?

$\square \quad \mathrm{x}$ is safety equipment required? (Please list...)

$\square \quad \square$ Are demand plots available?

$\times \quad \square$ Are facility diagrams avallable? 
$\square \quad x \quad$ is an equipment list available (with motor size and heating ratings)?

$x \quad \square$ Have copies of the site's utility bills for the last 12 months been assembled? (electric, gas, sewer \& water, as applicable)

\section{ENERGY CONSERVATION OPPORTUNITIES}

Previous Energy Conservation Assessments (state, consulting, utility, etc.): consulting

Existing Energy Conservation Measures (lighting, motors, etc.):

Energy Management Svstem - non functional

Current Areas of Concern (Energy or otherwise...): General

Potential Assessment Recommendation Opportunities:

Thank you for taking the time to complete this form. 


\section{APPENDIX B - Leakage in the compressed air system}

The following air leaks were found during the assessment week. Leaks have been roughly classified into small $(0-29 \mathrm{~cm})$, medium $(30-100 \mathrm{cfm})$, large $(100-300 \mathrm{cfm})$ and huge $(>300 \mathrm{ctm})$. Where leaks could be measured (msrd), they were. Where the hole size and pressure were known, leaks were calculated (calcd). In some cases a rough comparative estimate (estd) could be made. Unfortunately the huge leaks were indeterminable because the extreme air velocities and volume flowrates.

This table is intended as a guide for beginning the process of repairing the air leaks. Additional leaks are probable and can be most easily detected and repaired by plant maintenance personnel during non-production periods when the hiss of the air leaks will be easier to detect. Huge and large leaks are bold printed.

\begin{tabular}{|c|c|c|c|c|}
\hline No. & $\begin{array}{l}\text { Location: Press Shop, } \\
\text { Upper level, Presses }\end{array}$ & Description & Size category & $\begin{array}{c}\text { Waste } \\
\text { estimate } \\
\text { (cfm) }\end{array}$ \\
\hline 1 & F37848 & leak above beam of press & medium & \\
\hline 2 & F37848 & $\begin{array}{l}9 \mathrm{~mm} \text { ID hose blowing freely. No end } \\
\text { connector. }\end{array}$ & medium & $30 \mathrm{cfm}, \mathrm{msrd}$ \\
\hline 3 & B15696 & pressed part lifter mechanism & large & \\
\hline 4 & B1 5697 & central connector & medium & \\
\hline 5 & A2 4659 & piston area, both sides & medium & \\
\hline 6 & A1 4628 & 4 - way valve & large & \\
\hline 7 & D2 4890 & above press beam & medium & \\
\hline 8 & D2 4890 & leaks at pressure control valves & small & \\
\hline 9 & D5 4893 & leak at die & small & \\
\hline 10 & D5 4893 & $\begin{array}{l}\text { table cushion control valve } 7 \text { bar } \\
\text { through } 4,2 \mathrm{~mm} \text { hole }\end{array}$ & medium & $50 \mathrm{cfm}$, calcd \\
\hline 11 & E67851 & connector for hose on die & large & \\
\hline 12 & E6 7851 & hole in orange hose & large & \\
\hline 13 & E6 7851 & $\begin{array}{l}\text { connector to blue hose on south side } \\
\text { of press }\end{array}$ & small & \\
\hline 14 & E5 5483 & leaking $T$ (blue pipe on wall side) & small & \\
\hline 15 & E5 5483 & $\begin{array}{l}\text { connector to blue hose on south side } \\
\text { of press }\end{array}$ & medium & $40 \mathrm{cfm}$, estd \\
\hline 16 & E5 5483 & inside post (side) of press & indet. & \\
\hline 17 & C48604 & above press beam & small & \\
\hline 18 & F5 6262 & above press beam & small & \\
\hline 19 & B3 5697 & upper press & large & \\
\hline 20 & B2 5698 & press sides & small & \\
\hline 21 & C38603 & flexible hose to tool car (C5) & small & \\
\hline 22 & C5 10292 & connector of tool car flexible hose & small & \\
\hline 23 & F17850 & die manifold fed by green hose & large & $\begin{array}{l}130 \mathrm{cfm}, \\
\text { msrd }\end{array}$ \\
\hline 24 & F2 5486 & $\begin{array}{l}\text { connector to blue hose on south side } \\
\text { of press }\end{array}$ & medium & $30 \mathrm{cfm}$, estd \\
\hline 25 & E35485 & above press beam & medium & $80 \mathrm{cfm}$, estd \\
\hline 26 & D3 4891 & leaks at pressure control valves & small & \\
\hline
\end{tabular}




\begin{tabular}{|c|c|c|c|c|}
\hline 27 & D1 4894 & black hoses above press beam & medium & \\
\hline No. & $\begin{array}{l}\text { Location: Press Shop, } \\
\text { Lower level below } \\
\text { presses, South side }\end{array}$ & Description & Size & $\begin{array}{l}\text { Waste } \\
\text { estimate } \\
\text { (cfm) }\end{array}$ \\
\hline 28 & $\begin{array}{l}\text { Electrical cabinet } \\
\text { (EC) } 7849\end{array}$ & $\begin{array}{l}10 \mathrm{~mm} \text { iD drain hose, permanently } \\
\text { open (during entire week), (8mm @ } \\
6 \text { bar) }\end{array}$ & large & $\begin{array}{l}220 \mathrm{cfm} \\
\text { calcd }\end{array}$ \\
\hline 29 & $\begin{array}{l}\text { opposite EC no.4 } \\
(14 / 800 / 115)\end{array}$ & leaking valve & small & $30 \mathrm{cfm}$ estd \\
\hline No. & $\begin{array}{l}\text { Location: Press Shop, } \\
\text { Lower level below } \\
\text { presses, North side }\end{array}$ & Description & Size & $\begin{array}{l}\text { Waste } \\
\text { estimate } \\
\text { (cfm) }\end{array}$ \\
\hline 30 & $\begin{array}{l}\text { Between EC's TAG- } \\
4628 \text { and TAG-4888 }\end{array}$ & $\begin{array}{l}10 \mathrm{~mm} \text { ID blowdown pipe } \\
\text { permanently open (whole week), } \\
\text { (8m @ 6bar) }\end{array}$ & large & $\begin{array}{l}220 \mathrm{cfm} \\
\text { calcd }\end{array}$ \\
\hline 31 & $\begin{array}{l}\text { opposite EC TAG- } \\
48888\end{array}$ & leaking oil separator & small & \\
\hline 32 & $\begin{array}{l}\text { 6th receiver from East } \\
\text { end }\end{array}$ & leaking union & small & $40 \mathrm{cfm}$, estd \\
\hline 33 & $\begin{array}{l}\text { 3rd receiver from East } \\
\text { end }\end{array}$ & hole in valve $(2 \mathrm{~mm}), 6$ bar & small & $16 \mathrm{cfm}$, calcd \\
\hline 34 & $\begin{array}{l}\text { green cylinder closest } \\
\text { to EC TAG } 5698\end{array}$ & air leak & small & \\
\hline 35 & $\begin{array}{l}\text { 4th receiver from East } \\
\text { end }\end{array}$ & leak in pipework & medium & \\
\hline 36 & above EC 7851 & leaking coupling on $12 \mathrm{~mm}$ pipe & small & \\
\hline No. & $\begin{array}{l}\text { Location: Paint Shop, } \\
\text { Ground floor }\end{array}$ & Description & Size category & $\begin{array}{l}\text { Waste } \\
\text { estimate } \\
\text { (cfm) }\end{array}$ \\
\hline 37 & Station 26 & air leak on hose coupling & small & \\
\hline 38 & Group 8 & air leak on hose coupling & small & \\
\hline 39 & $\begin{array}{l}\text { Station } 10, \text { Graco } \\
\text { spray machine }\end{array}$ & air leak on hose coupling & medium & \\
\hline 40 & $\begin{array}{l}\text { Station 5, Graco spray } \\
\text { machine }\end{array}$ & leak & small & \\
\hline 41 & $\begin{array}{l}\text { directly above EC } \\
\text { marked "Main switch" }\end{array}$ & leak at hose feeder & medium & \\
\hline 42 & $\begin{array}{l}\text { stations } 1 \text { to } 10 \\
\text { directly after 'blowing' } \\
\text { oven }\end{array}$ & a number of leaks & small & \\
\hline 43 & $\begin{array}{l}\text { self etching spray } \\
\text { booth }\end{array}$ & leak in hose & small & \\
\hline 44 & primer bay $\sin 7$ and 8 & leak in hose coupling & medium & \\
\hline 45 & $\begin{array}{l}\text { wet on wel and } \\
\text { blackout booth }\end{array}$ & leak in hose & small & \\
\hline 46 & paint mix room & leaking crane & small & \\
\hline 47 & paint mix room & open ended 5,5mm hose @6,6 bar & medium & $60 \mathrm{cfm}$ calcd \\
\hline No. & $\begin{array}{c}\text { Location: Assembly } \\
\text { Hall }\end{array}$ & Description & Size category & $\begin{array}{l}\text { Waste } \\
\text { estimate } \\
\text { (cfm) }\end{array}$ \\
\hline 48 & $\begin{array}{l}\text { vehicle lift crane, citi- } \\
\text { golf line }\end{array}$ & airleak on Haden vehicle lift & medium & \\
\hline 49 & $\begin{array}{l}\text { at main road entrance, } \\
\text { AR } 45\end{array}$ & auto-blowdown valve stuck open & huge & \\
\hline 50 & $\begin{array}{l}\text { where cars cross isle J } \\
\text { overhead }\end{array}$ & air leak & medium & \\
\hline
\end{tabular}




\begin{tabular}{|c|c|c|c|c|}
\hline 51 & $\begin{array}{l}\text { station 56, opposite } \\
\text { BH54 }\end{array}$ & leaking air filter & small & \\
\hline 52 & $\begin{array}{l}\text { between stations } 39 \\
\text { and } 40\end{array}$ & leaking hose on air filter & small & \\
\hline 53 & $\begin{array}{l}\text { just below roof, above } \\
\text { sign "B5 Audi Fine } \\
\text { Finishing Line" }\end{array}$ & air leak & medium & \\
\hline 54 & collumn next to AV58 & leaking air filter & small & \\
\hline 55 & $\begin{array}{l}\text { station } 54 \text { alongside } \\
\text { stairway in isle F }\end{array}$ & $\begin{array}{l}\text { open } 10 \mathrm{~mm} \text { hose (tied to collumn } \\
\text { to prevent it from thrashing } \\
\text { around),(8mm @ } 6 \text { bar) }\end{array}$ & large & $\begin{array}{l}150 \mathrm{ctm} \\
\text { calcd }\end{array}$ \\
\hline 56 & $\begin{array}{l}\text { Ist level, station } 8 \\
\text { above isle E }\end{array}$ & greasing tool, $4 \mathrm{~mm}$ hole, 6 bar & medium & $50 \mathrm{cfm}$ calcd \\
\hline 57 & $\begin{array}{l}\text { station } 16 \text { zone } 4 \text { on } \\
\text { Golf line }\end{array}$ & leak in hose & small & \\
\hline 58 & $\begin{array}{l}\text { on roof, } 2 \times 8 \mathrm{~mm} \\
\text { copper pneumatic } \\
\text { tubing }\end{array}$ & tubing not closed off properly & medium & \\
\hline No. & Location: Body Shop & Description & Size category & $\begin{array}{l}\text { Waste } \\
\text { estimate } \\
\text { (cfm) }\end{array}$ \\
\hline 59 & $\begin{array}{l}\text { right-hand side of } \\
\text { main road entrance, } \\
\text { AL44 }\end{array}$ & $\begin{array}{l}\text { auto-blowd own stuck open, outlet } \\
\text { feeds into NE downpipe, very } \\
\text { noisy }\end{array}$ & huge & Indet. \\
\hline 60 & $\begin{array}{l}\text { North side of two } \\
\text { Atlas Copco LT } \\
\text { compressors }\end{array}$ & $\begin{array}{l}\text { leaking main line flange or } \\
\text { blowdown stuck open }\end{array}$ & large & Indet \\
\hline No. & $\begin{array}{c}\text { Location: Pressed Part } \\
\text { Warehouse }\end{array}$ & Description & Size category & $\begin{array}{l}\text { Waste } \\
\text { estimate } \\
\text { (cfm) }\end{array}$ \\
\hline 61 & Blue oiler plant & leak in hose & small & \\
\hline 62 & $\begin{array}{l}\text { halfway between Eng. } \\
\text { Workshop and West } \\
\text { wall }\end{array}$ & leak in main $5 "$ airline & medium & \\
\hline
\end{tabular}


APPENDIX C - Lighting levels in the plant

The following colours have been used to indicate light levels (in lux) in each part of the plant: Building outlines are not to scale.

\begin{tabular}{|c|c|c|c|c|c|c|c|}
\hline light level (lux) & & & $120-$ & $240-$ & $280-$ & $600-$ & \\
& $0-40$ & $40-120$ & 240 & 280 & 600 & 2000 & $>2000$ \\
\hline colour & & & & & & & \\
\hline
\end{tabular}

Machining Hall: Date: 07.08.2001 Time: 15:00-16:00

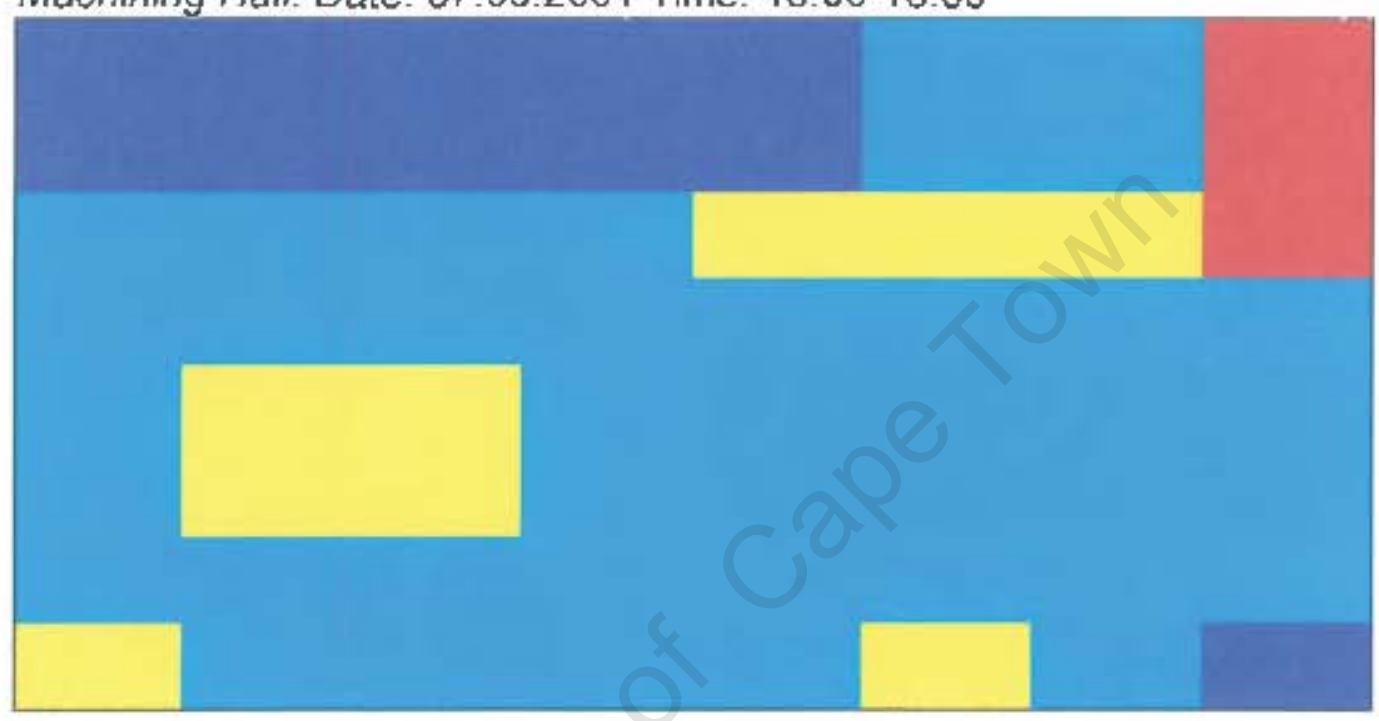

Assembly Hall: Date: 08.08.2001 Time: 16:00-17:00

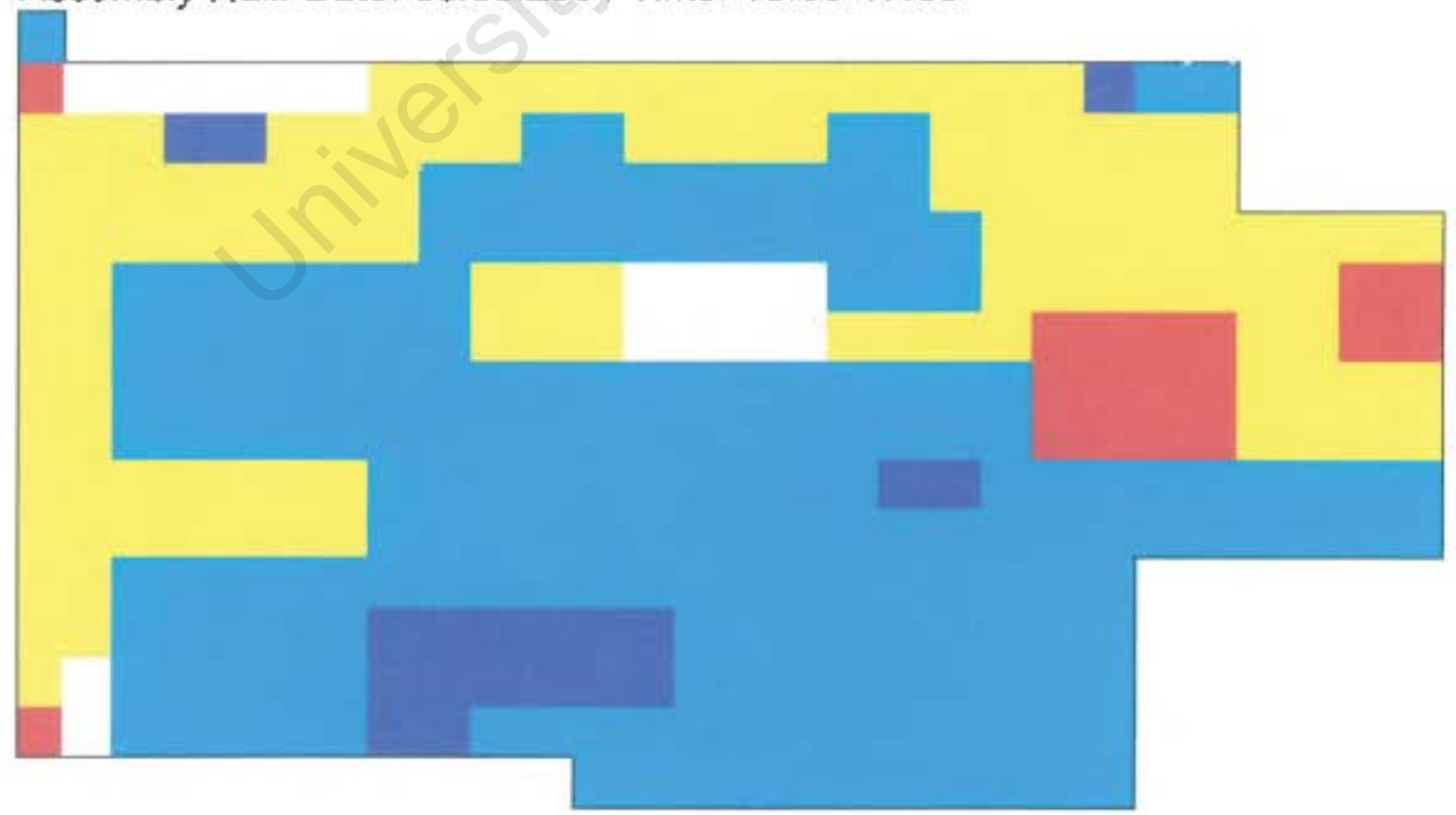


Body Shop: Date: 09 08.2001 Time: 13:00-15:00 and Press Shop: Date: 11.08.2001 Time: 14:45-15:30 and

Steel and Heavy Tool Store: Date: 22/10/2001 Time: 13:30 - 14:00

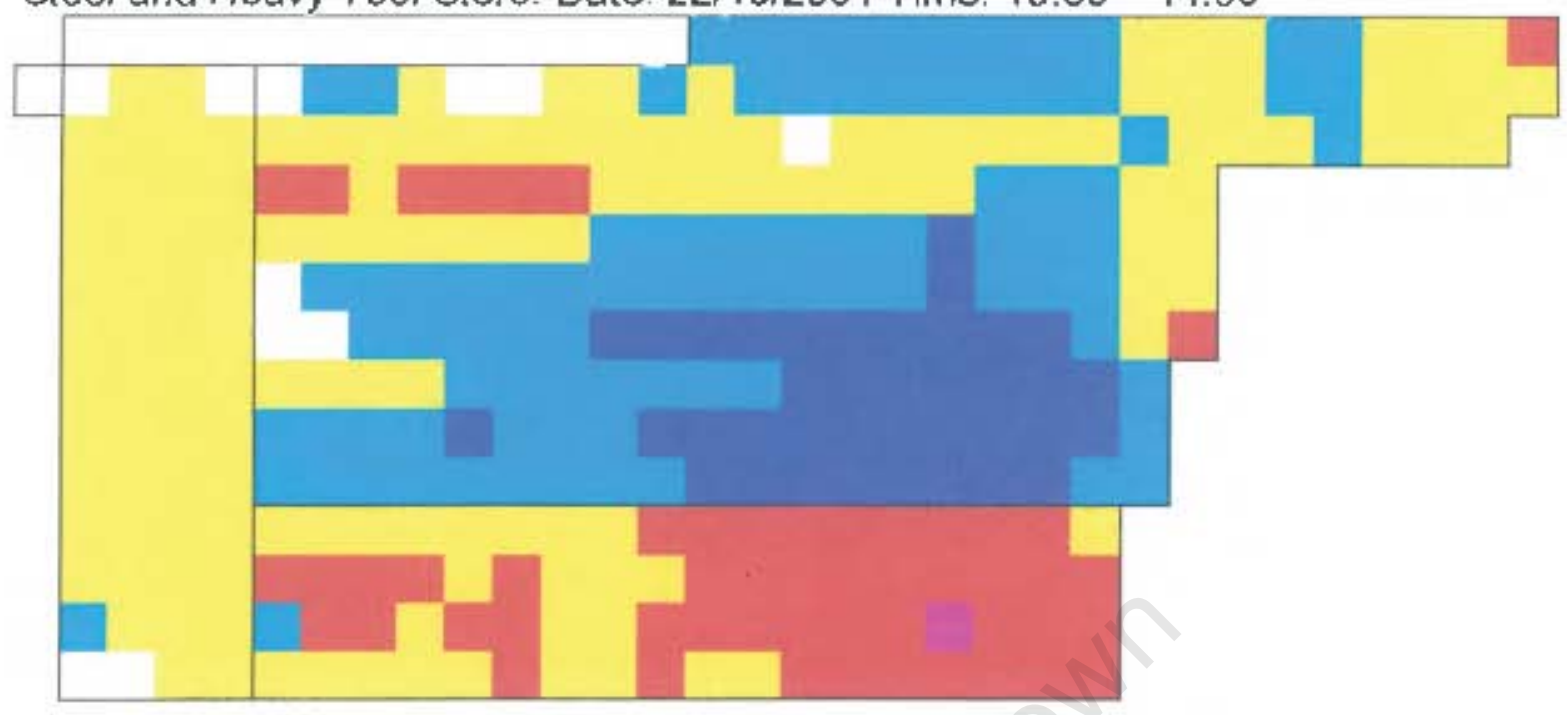

Pressed Part Warehouse: Date: 11/08/2001 Time: 14:00 - 14:45

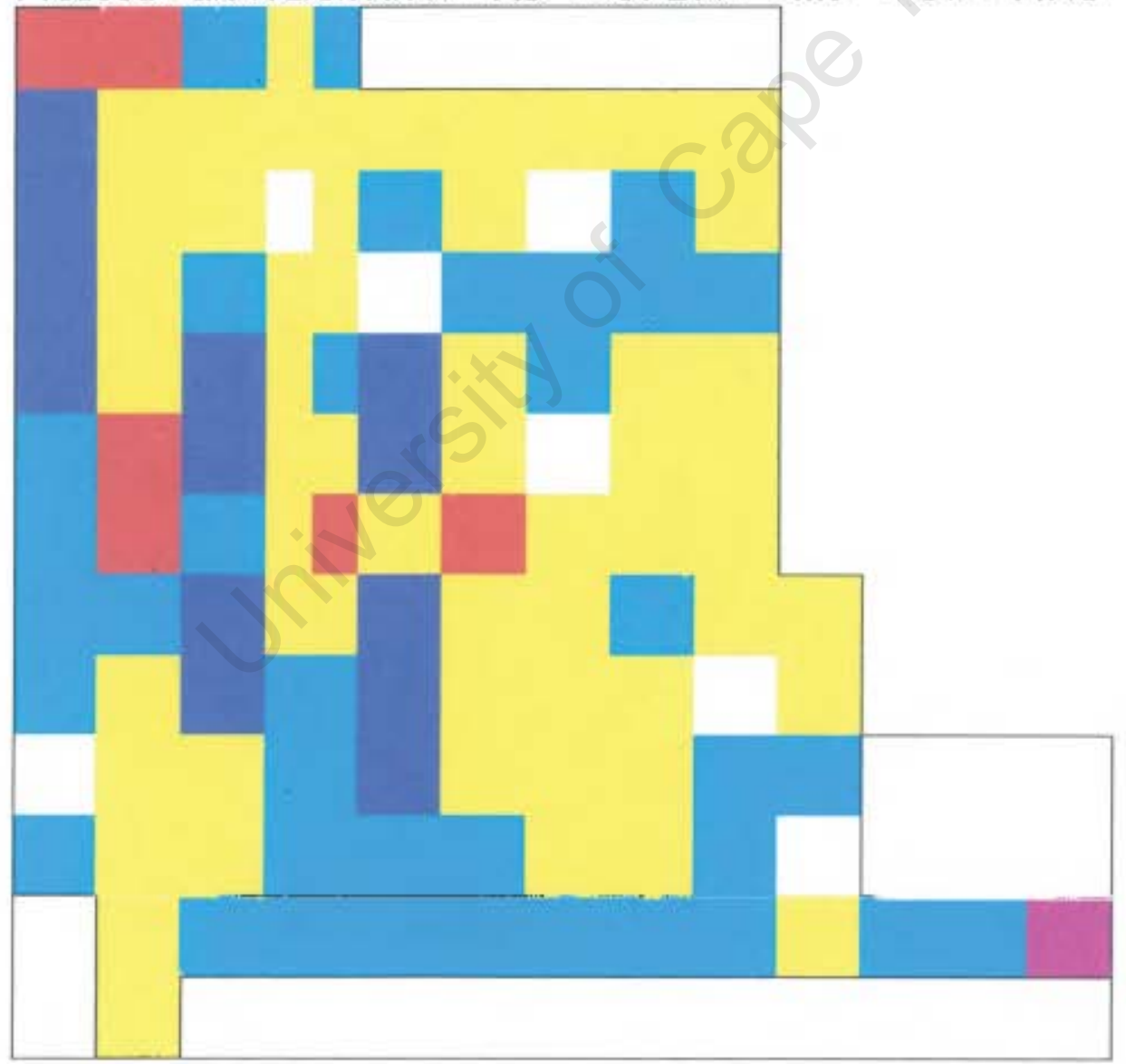


Container Warehouse: Date: 11/08/2001 Time: 10:00 -11:00

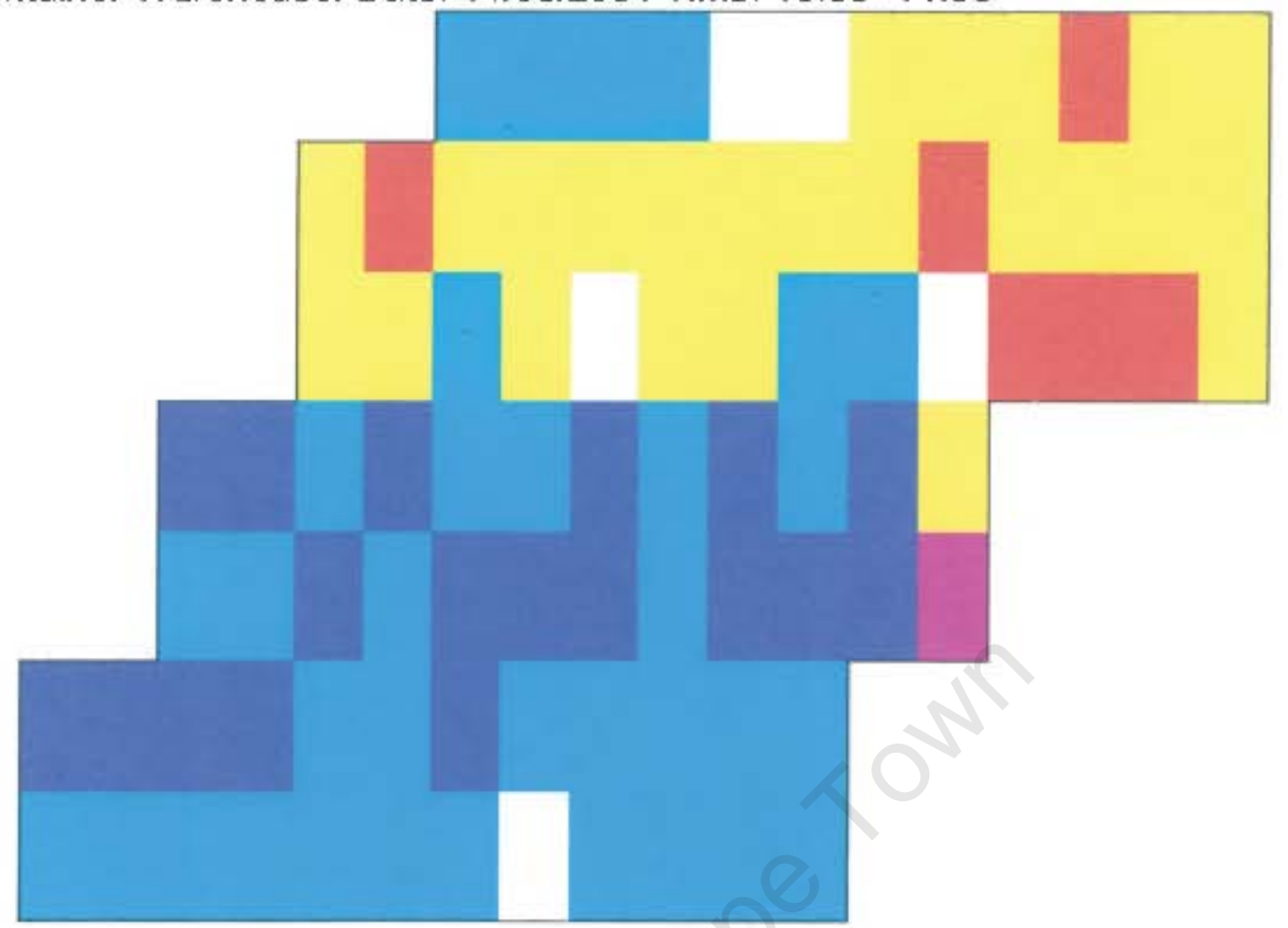




\section{APPENDIX D - Lamp replacement calculations}

The estimated energy conservation, $E C$, for replacing lamps in a specific area is given by:

$$
E C=\left[N \times(C F W-P F W \times H] / C_{1}\right.
$$

where,

$N=$ number of fixtures in area, no units

$C F W=$ power rating of current fixtures in area, $W$

$P F W=$ power rating of proposed fixtures in area, $W$

$H=$ operating hours of lamp in area, $\mathrm{h} / \mathrm{yr}$

$C_{1}=$ conversion constant, $1,000 \mathrm{~W} / \mathrm{kW}$

The demand reduction (DR) associated with replacing lamps in a specific area is given by:

$D R=\left[N \times\left(C F W-P F W \times C F / C_{1}\right.\right.$

where

$$
\begin{aligned}
& C F= \text { coincidence factor - probability that the equipment contributes } \\
& \text { to the facility peak demand, per month }
\end{aligned}
$$

The change in annual lamp replacement cost ( $L R C$ - which may be positive or negative)for a specific area is given by:

$L R C=[(N E L \times E L C / E L L)-(N P L \times P L C / P L L)] \times H$

where

$N E L=$ number of existing lamps

$E L C=$ existing lamp cost, ZAR

$E L L=$ existing average lamp life, hours

$N P L=$ number of proposed lamps

$P L C=$ proposed lamp cost, ZAR

$P L=$ proposed average lamp life, hours

Therefore, the total annual cost savings, TCS, can be estimated as follows:

$\mathrm{TCS}=(E C \times$ energy rate $)+\left(\mathrm{DR} \times\right.$ demand rate $\left.^{(1)} \times 12 \mathrm{mo} / \mathrm{yr}\right)+\mathrm{LRC}$

(1) Assumption: Maximum chargeable demand 
Avoided Electric Cost: R 0,17978/kWh

Avoided Demand Cost: R 35,973/kW

The total implementation cost is:

$T I C=R 63440+R 32760+R 98+R 13000=R 109298$

The simple payback period is:

Simple payback $=109298 / 35728=3,1$ years 


\section{APPENDIX E - Incremental relamping (spot and group \\ relamping)}

A common practice for many facilities is to relamp on a spot basis as the lamps burn out or group relamp a fraction of the fixtures in an area of the plant at periodic time intervals depending upon the rated life of the lamps and the annual usage hours of the lamps. These methods of relamping spread the total implementation cost over several years, as lamps are replaced only as the existing lamps burn out. The purpose of this section is to present estimates of the annual cost savings and implementation costs that are expected for the first two years if these methods of relamping are followed.

The annual savings due to replacing burned out conventional lamps with energy efficient lamps will depend on the life of the old lamps. Assuming an even distribution of lamp life throughout the areas considered, the current annual lamp replacement fraction, $f$, is estimated as follows:

$$
f=H / C L L
$$

where $H$ is the number of hours that the lamp operates per year and $C L L$ is current lamp life in hours. As an example, the lamp replacement fraction $(f)$ for the Machining Hall, where lamps are turned on for $8760 \mathrm{~h} / \mathrm{yr}$ with lamps that have an average life of 24000 hours (only looking at $400 \mathrm{~W}$ MV), is calculated as follows:

$$
f=8760 / 24000=0,365
$$

This value can be used to estimate the number of lamps of a specific type that will burn out each year. All lamps in a fixture are assumed to be of equal age, thus the lamp replacement fraction also represents the fixture replacement fraction for each area of the facility. The energy savings for an area after the first year would be the fraction of fixtures that burn out in that area in a given year multiplied by the difference in the total projected and total current electrical energy usage for all fixtures in that area. Each succeeding year more of the original lamps, ballasts and igniters are replaced with energy efficient lamps, ballasts and igniters. Thus, the incremental energy conservation in the $n^{\text {th }}$ year, $I E S_{n}$, can be estimated as follows:

$I E S_{n}=n \times f \times E S$

The incremental savings cannot be greater than the total savings when all the lamps, ballasts and igniters have been replaced (i.e., if $f \times n>1$, then $f \times$ 
$n=1)$. As an example, the incremental energy conservation that can be realized in the first year $(n=1)$ for the Machining Hall, IES $S_{1}$, is as follows:

$I E S_{1}=(1)(0,365)(362,14)=132,18 \mathrm{kWh} / \mathrm{yr}$

Similarly, the incremental cost savings after the $n^{\text {th }}$ year, $I C S_{n}$, can be estimated as follows:

$I C S_{n}=n \times f \times C S$

As an example, the incremental cost savings that can be realized in the first year for the Machining Hall are, $I C S_{1}$, are calculated as follows:

$I C S_{1}=(1)(0,365)(29649)=\mathrm{R} 10822$

The incremental implementation cost for an area is equal to the fraction of fixtures in that area requiring replacement in a given year multiplied by the sum of the differential lamp costs, ballast and igniter costs for that area and labor costs (because ballasts and igniters are being installed). Except for the final year of lamp and ballast and igniter replacement, each year will have the same fraction of fixture replacement and thus equal incremental implementation costs. Each successive year will also have increasing cost savings. The final year will usually have a smaller fraction of fixtures to replace and thus a lower incremental implementation cost. The annual incremental implementation cost, $/ I C$, can be calculated as follows:

For years 1 to $(n-1)$ :

$\| C_{n}=f \times[$ differential lamp cost + ballast cost + igniter cost + labour cost $]$

For year $\mathrm{n}$ :

$\| C_{n}=[1-((n-1) \times f] \times[$ differential lamp cost + ballast cost + igniter cost + labour cosf]

The incremental cost savings and implementation costs for the remaining lamps in the facility are listed in the following tables. 


\begin{tabular}{|c|c|c|c|c|c|c|c|c|c|c|c|c|c|}
\hline Building Area & $\begin{array}{c}\text { Annual } \\
\text { Usage } \\
\text { Time } \\
h / y r\end{array}$ & $\begin{array}{l}\text { Rated } \\
\text { Lamp } \\
\text { Life } \\
\text { hours }\end{array}$ & $\begin{array}{c}\text { Annual } \\
\text { Replacement } \\
\text { Fraction }\end{array}$ & $\begin{array}{c}\text { 1st Year } \\
\text { Energy } \\
\text { Savings } \\
k W h\end{array}$ & $\begin{array}{c}\text { 1st Year } \\
\text { Demand } \\
\text { Savings } \\
\mathrm{kW}\end{array}$ & $\begin{array}{c}\text { 1st Year } \\
\text { Energy } \\
\text { Cost } \\
\text { Savings }\end{array}$ & $\begin{array}{c}\text { Ist Year } \\
\text { Demand } \\
\text { Cost } \\
\text { Savings }\end{array}$ & $\begin{array}{c}1 \text { st Year } \\
\text { Cost } \\
\text { Savings }\end{array}$ & $\begin{array}{c}\text { 2nd Year } \\
\text { Energy } \\
\text { Savings } \\
\text { kWh }\end{array}$ & $\begin{array}{c}\text { 2nd Year } \\
\text { Demand } \\
\text { Savings } \\
\mathrm{kW}\end{array}$ & $\begin{array}{c}\text { 2nd Year } \\
\text { Energy } \\
\text { Cost } \\
\text { Savings }\end{array}$ & $\begin{array}{c}\text { 2nd Year } \\
\text { Demand } \\
\text { Cost } \\
\text { Savings }\end{array}$ & $\begin{array}{c}\text { 2nd Year } \\
\text { Cost } \\
\text { Savings }\end{array}$ \\
\hline Machining Hall & 60 & 000 & $36,5 \%$ & 32181 & 181,1 & 3763 & 6514 & 30277 & 264361 & 362,1 & 7527 & 13027 & 55 \\
\hline Machining Hall & 60 & 24000 & $5 \%$ & 2590 & 3,5 & 466 & 128 & 593 & 5180 & 7,1 & 931 & 255 & 118 \\
\hline & 760 & 24000 & $36,5 \%$ & 93543 & 128,1 & 16817 & 4610 & 21427 & 187086 & 256,3 & 33634 & 9219 & 4285 \\
\hline art & 760 & 24000 & $36,5 \%$ & 503 & 19,9 & 07 & 715 & 3322 & 07 & 39,7 & 5215 & 1429 & 64 \\
\hline & 8760 & 24000 & $36,5 \%$ & $\begin{array}{ll}68 & 124\end{array}$ & 93,3 & 12247 & 3357 & 15604 & 136248 & 186,6 & 24495 & 6714 & 3120 \\
\hline e & 760 & 24000 & $36,5 \%$ & 30561 & 41,9 & 5494 & 1506 & 7000 & 61121 & 83,7 & 10988 & 3012 & 1400 \\
\hline Press Shop & 8760 & 24000 & $36,5 \%$ & 117437 & 160,9 & 21113 & 5787 & 26900 & 234875 & 321,7 & 42226 & 11574 & 5380 \\
\hline Body Shop & 760 & 24000 & $36,5 \%$ & 96593 & 132,3 & 17366 & 4760 & 22126 & 193187 & 264,6 & 34731 & 9520 & 4425 \\
\hline Body Shop & 760 & 24000 & $\%$ & 5698 & $78,8-3>$ & 1024 & 281 & 1305 & 396 & 15,6 & 049 & 562 & 61 \\
\hline Assembly Hall & 8760 & 24000 & $36,5 \%$ & 243517 & 333,6 & 43780 & 12009 & 55780 & 487034 & 667,2 & 87559 & 24000 & 11155 \\
\hline & 8760 & 24000 & $36,5 \%$ & 13985 & 19,2 & 2514 & 689 & 3203 & 27971 & 38,3 & 5029 & 1378 & 640 \\
\hline $\begin{array}{l}\text { Steel a } \\
\text { Store }\end{array}$ & 8760 & 24000 & $36,5 \%$ & 006 & 83,6 & 10968 & 3006 & 13974 & 122013 & 167,1 & 21935 & 013 & 27948 \\
\hline TALS & & & & 9 & 5,1 & 59 & 2 & I & 8 & 2 & 9 & 04 & FUS VL2 \\
\hline
\end{tabular}

Incremental Saving: 


\begin{tabular}{|c|c|c|c|c|c|c|c|c|c|c|c|c|c|}
\hline Building Area & $\begin{array}{c}\text { Annual } \\
\text { Usage } \\
\text { Time } h / y r \\
\end{array}$ & $\begin{array}{l}\text { Rated } \\
\text { Lamp } \\
\text { Life } \\
\text { hours } \\
\end{array}$ & \begin{tabular}{|c|} 
Annual \\
Replacem \\
ent \\
Fraction \\
\end{tabular} & \begin{tabular}{|c|} 
1st Year \\
Lamp \\
Cost \\
$R$ \\
\end{tabular} & $\begin{array}{c}\text { 1st Year } \\
\text { Ballast } \\
\text { Cost } \\
R \\
\end{array}$ & $\begin{array}{c}\text { 1st Year } \\
\text { Igniter } \\
\text { Cost } \\
\mathrm{R}\end{array}$ & $\begin{array}{c}\text { 1st Year } \\
\text { Labor } \\
\text { cost } \\
R \\
\end{array}$ & $\begin{array}{c}\text { Ist Year } \\
\text { Impleme } \\
\text { nt. Cost } \\
\mathrm{R}\end{array}$ & $\begin{array}{c}\text { 2nd Year } \\
\text { Lamp } \\
\text { Cost } \\
R\end{array}$ & $\begin{array}{c}\text { 2nd Year } \\
\text { Ballast Cost } \\
R\end{array}$ & $\begin{array}{c}\text { 2nd Year } \\
\text { Igniter } \\
\text { Cost } \\
R\end{array}$ & $\begin{array}{c}\text { 2nd Year } \\
\text { Labor cost } \\
R\end{array}$ & $\begin{array}{c}\text { 2nd Year } \\
\text { Implement } \\
\text { Cost } \\
R\end{array}$ \\
\hline $\begin{array}{l}\text { Machining } \\
\text { Hall }\end{array}$ & 8760 & 24000 & $36,5 \%$ & 23156 & 11957 & 36 & 4745 & 39894 & 46311 & 23915 & 72 & 9490 & 79788 \\
\hline $\begin{array}{l}\text { Machining } \\
\text { Hall }\end{array}$ & 8760 & 24000 & $36,5 \%$ & 445 & 230 & 36 & 91 & 802 & 891 & 460 & 72 & 183 & 1605 \\
\hline $\begin{array}{l}\text { Pressed Part } \\
\text { Warehouse }\end{array}$ & 8760 & 24000 & $36,5 \%$ & 16387 & 8462 & 36 & 3358 & 28243 & 32774 & 16924 & 72 & 6716 & 56486 \\
\hline $\begin{array}{l}\text { Pressed Part } \\
\text { Warehouse }\end{array}$ & 8760 & 24000 & $36,5 \%$ & 2494 & 1288 & 36 & 511 & 4328 & 4987 & 2575 & 72 & 1022 & 8656 \\
\hline $\begin{array}{l}\text { Container } \\
\text { Warehouse }\end{array}$ & 8760 & 24000 & $36,5 \%$ & 11934 & 6163 & 36 & 2446 & 20578 & 23868 & 12325 & 72 & 4891 & 41156 \\
\hline $\begin{array}{l}\text { Container } \\
\text { Warehouse }\end{array}$ & 8760 & 24000 & $36,5 \%$ & 5255 & 2713 & 36 & 1077 & 9080 & 10509 & 5427 & 72 & 2154 & 18161 \\
\hline Press Shop & 8760 & 24000 & $36,5 \%$ & 20573 & 10624 & 36 & 4216 & 35448 & 41146 & 21247 & 72 & 8432 & 70896 \\
\hline Body Shop & 8760 & 24000 & $36,5 \%$ & 16921 & 8738 & 36 & 3468 & 29163 & 33843 & 17476 & 72 & 6935 & 58326 \\
\hline Body Shop & 8769 & 24000 & $36,5 \%$ & 980 & 506 & 36 & 201 & 1722 & 1959 & 1012 & 72 & 402 & 3444 \\
\hline $\begin{array}{l}\text { Assembly } \\
\text { Hall }\end{array}$ & 8760 & 24000 & $36,5 \%$ & 42660 & 22029 & 36 & 8742 & 73466 & 85319 & 44058 & 72 & 17484 & 146933 \\
\hline $\begin{array}{l}\text { Assembly } \\
\text { Hall } \\
\text { Steel and }\end{array}$ & 8760 & 24000 & $36,5 \%$ & 2405 & 1242 & 36 & 493 & 4175 & 4809 & 2483 & 72 & 986 & 8350 \\
\hline $\begin{array}{l}\text { Heavy Tool } \\
\text { Store }\end{array}$ & 8760 & 24000 & $36,5 \%$ & 10687 & 5519 & 36 & 2190 & 18432 & 21374 & 11038 & 72 & 4380 & 36864 \\
\hline TOTALS & & & & 153896 & 79471 & 429 & 31536 & 265332 & 307791 & 158941 & 858 & 63072 & 530663 \\
\hline
\end{tabular}


APPENDIX F - Condition of skylights in main workplaces

\begin{tabular}{l|} 
Key \\
\begin{tabular}{|l|l|}
\hline Clean & \\
\hline Fairly Clean \\
\hline Dirty \\
\hline
\end{tabular}
\end{tabular}

Machining Hall:

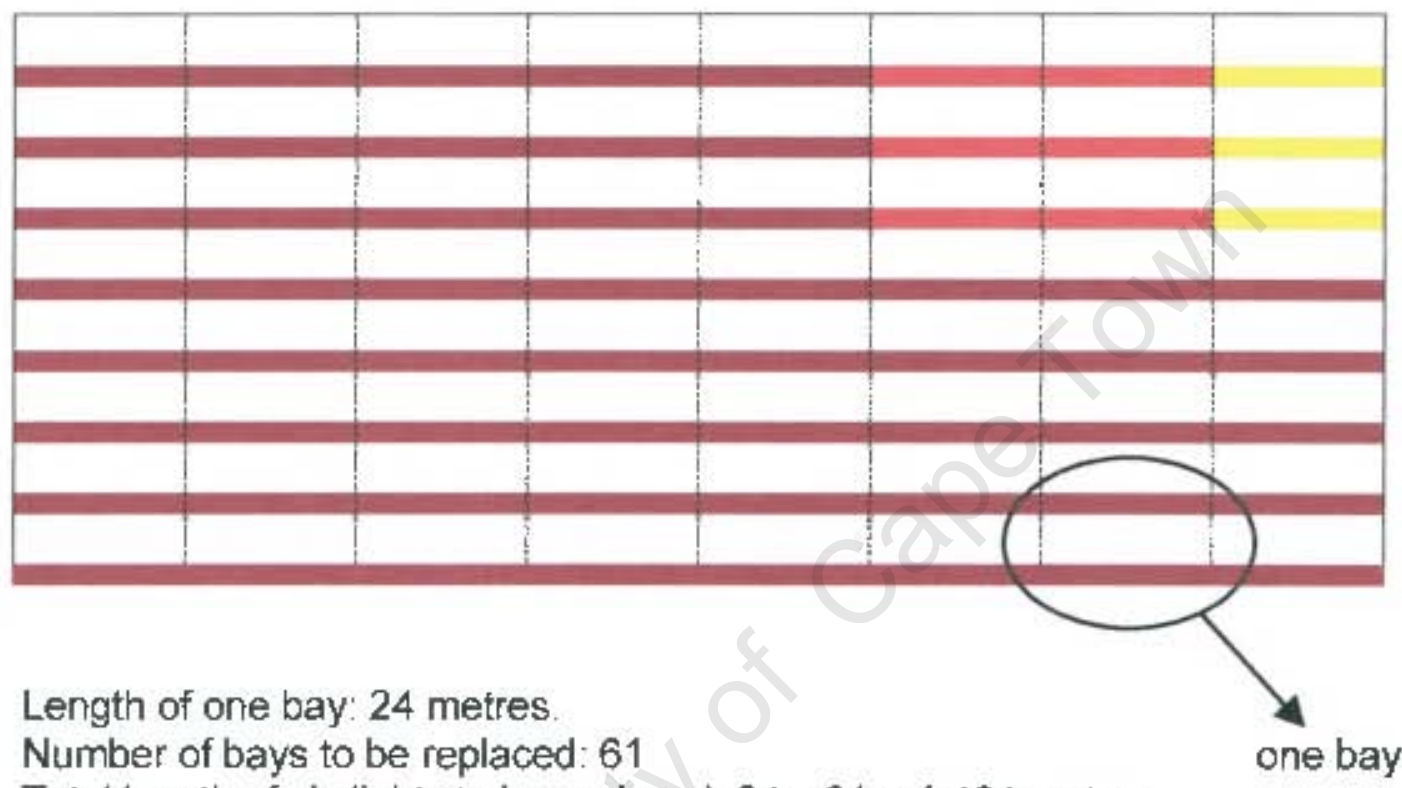

Total length of skylights to be replaced: $24 \times 61=1464$ metres 
Body Shop, Press Shop, Steet and Heavy Tool Store:

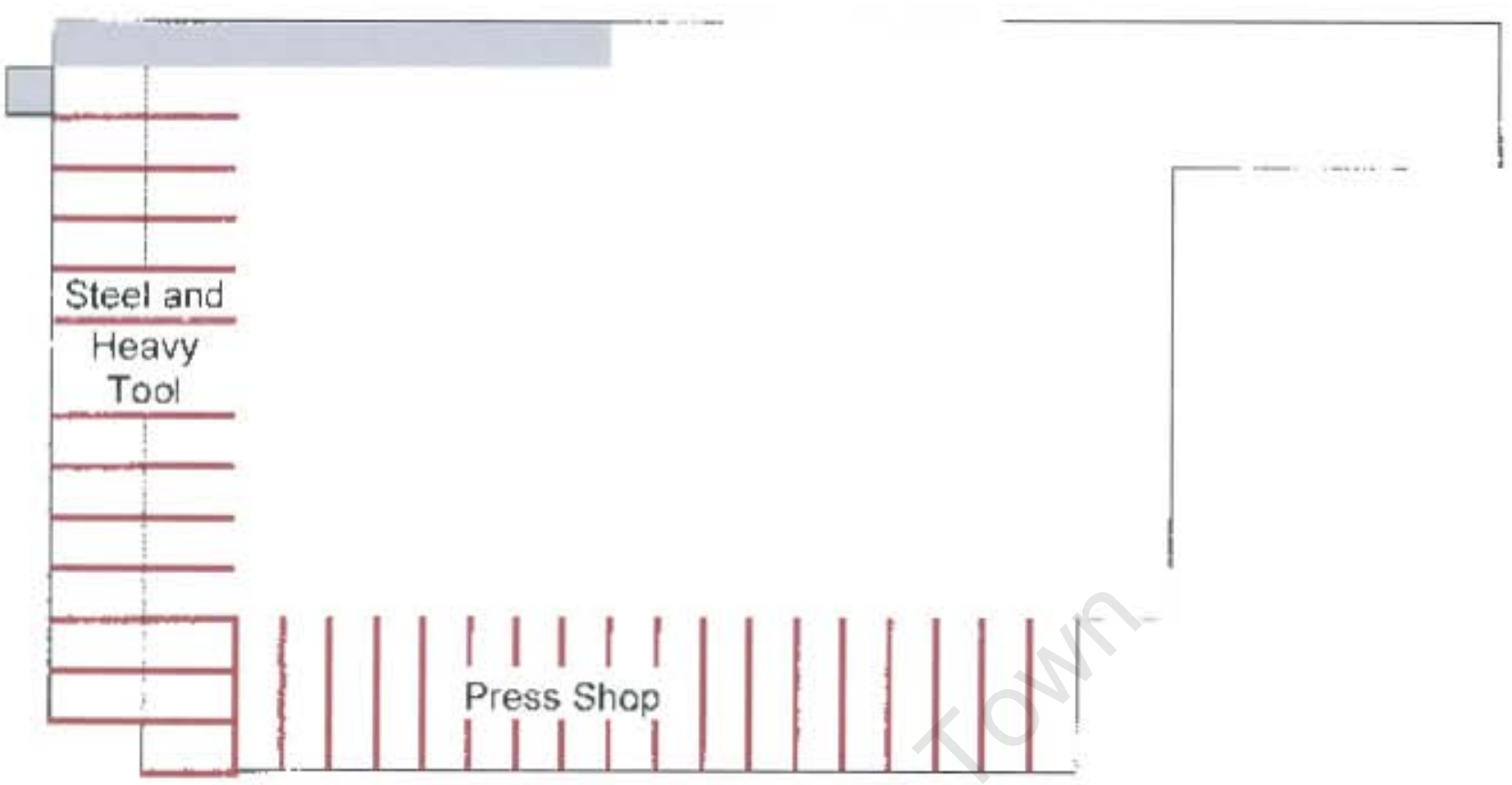

(The rest of the skylights are plate-glass skylights and are therefore not market in the drawing)

The following data was measured, but positions not recorded:

Steel Slore \& Heavy Tool :

Length of one bay: 24 metres

Number of bays to be replaced: 25

Total length of skylights to be replaced: $24 \times 25=600$ metres

Press Shop:

Length of one bay: 36 metres

Number of bays to be replaced: 18

Total length of skylights to be replaced: $36 \times 18=648$ metres 


\section{Container Warehouse:}

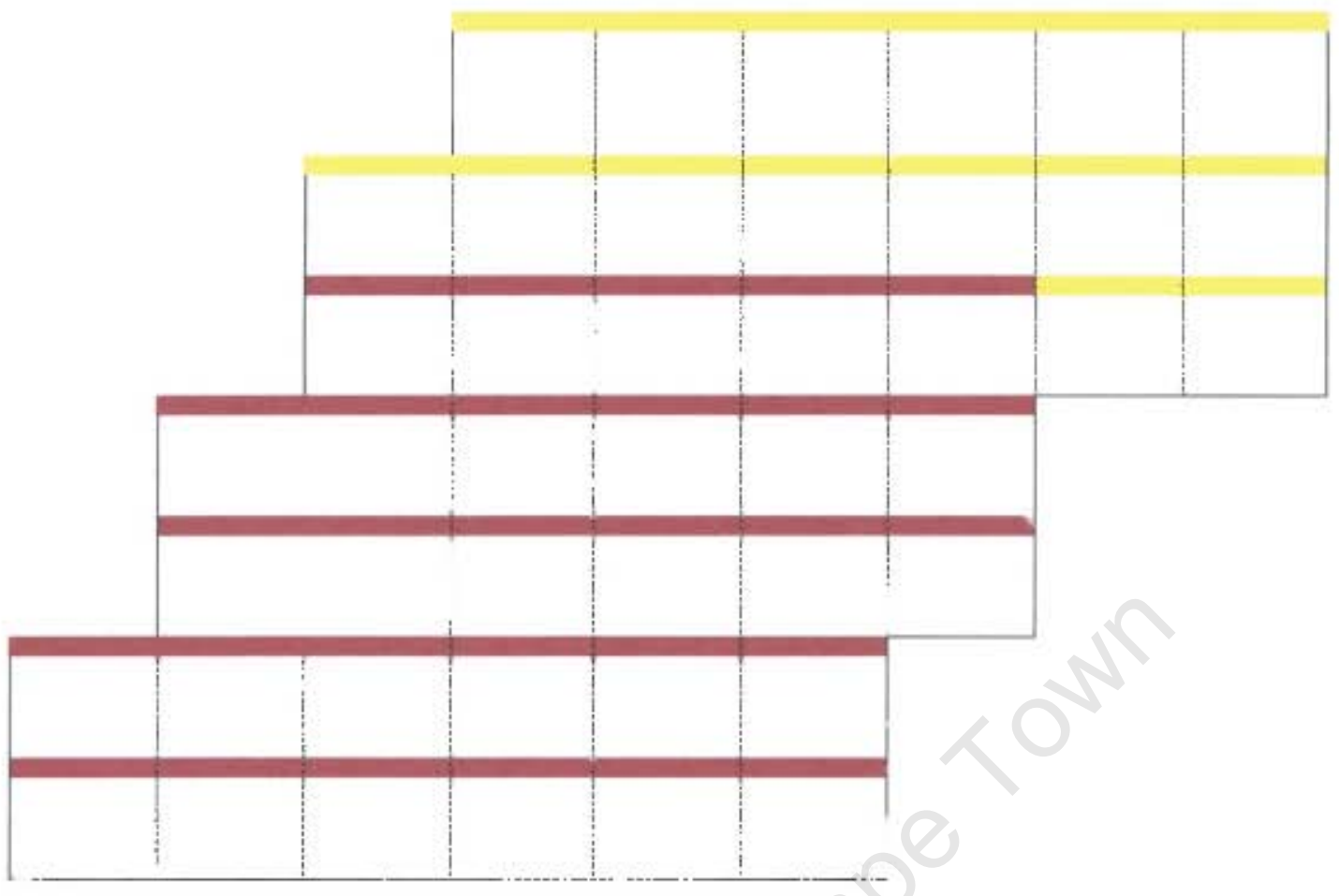

Length of one bay: 24 metres.

Number of bays to be replaced: 29

Total length of skylights to be replaced $24 \times 29=696$ metres 
Appendix G - Plant layout diagram

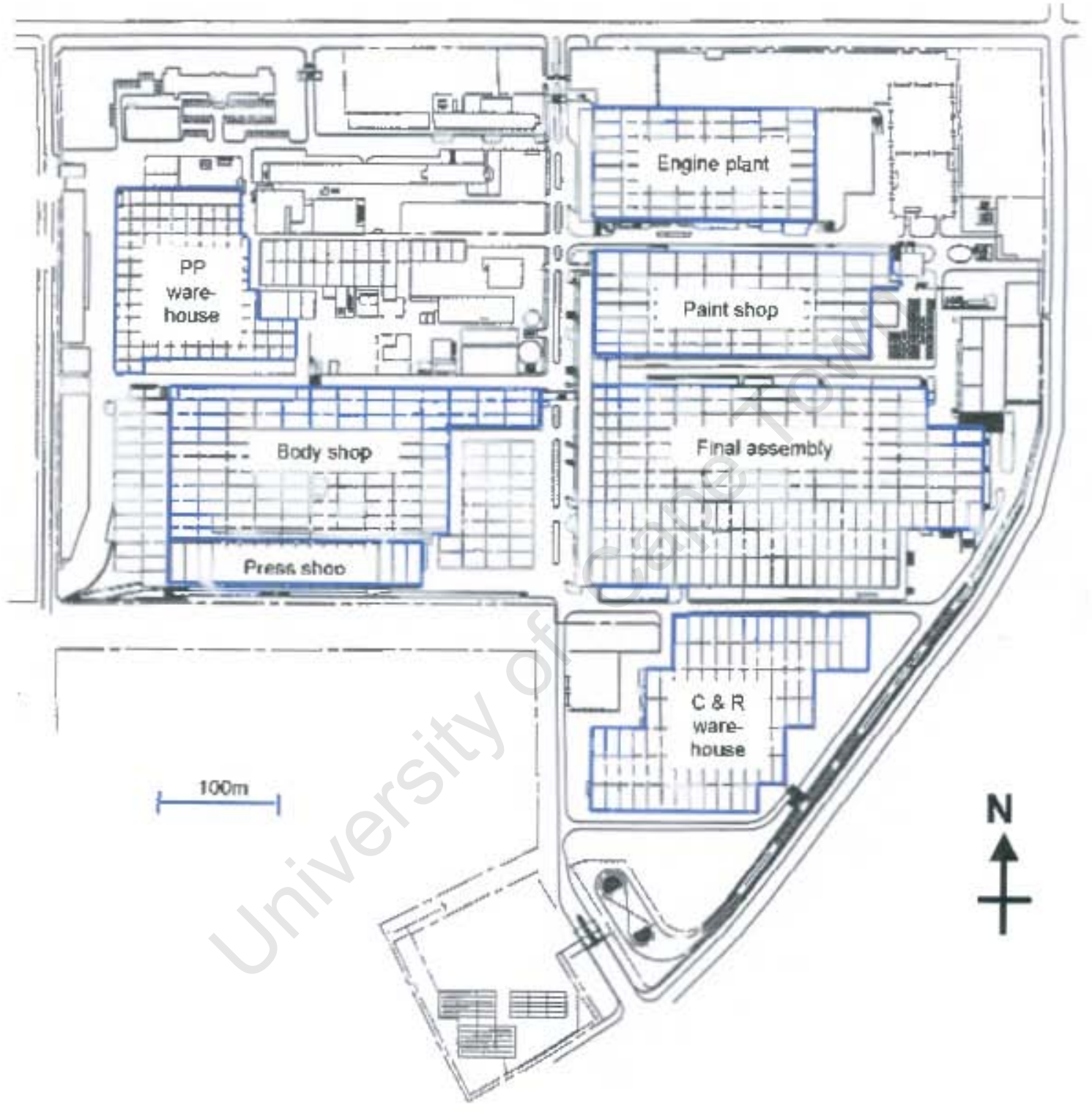

